MARCELO CHILVARQUER

A implementação do Programa Minha Casa, Minha Vida Faixa 1 no Município de São Paulo

\author{
Dissertação de Mestrado \\ Orientador: Professor Diogo Rosenthal Coutinho
}

UNIVERSIDADE DE SÃO PAULO

FACULDADE DE DIREITO

São Paulo - SP

2018 


\title{
MARCELO CHILVARQUER
}

\section{A implementação do Programa Minha Casa, Minha Vida Faixa 1 no Município de São Paulo}

\begin{abstract}
Dissertação apresentada à Banca
Examinadora do Programa de PósGraduação em Direito, da Faculdade de Direito da Universidade de São Paulo, como exigência parcial para obtenção do título de Mestre em Direito, na área de concentração de Direito Econômico e Economia Política, sob orientação do Professor Diogo Rosenthal Coutinho.
\end{abstract}

SÃO PAULO 
Chilvarquer, Marcelo

A implementação do Programa Minha Casa, Minha Vida Faixa 1 no Município de São Paulo / Marcelo Chilvarquer

-- São Paulo, 2018

$189 \mathrm{f}$.

Orientador: Diogo Rosenthal Coutinho

Dissertação (mestrado) - Universidade de São Paulo, Faculdade de Direito 
Nome: CHILVARQUER, Marcelo

Título: A implementação do Programa Minha Casa, Minha Vida Faixa 1 no Município de São Paulo

Dissertação apresentada à Faculdade de Direito da Universidade de São Paulo para obtenção do título de Mestre em Direito.

Aprovado em:

Banca Examinadora

Prof. Dr. Instituição:

Julgamento: Assinatura:

Prof. Dr. Instituição:

Julgamento: Assinatura:

Prof. Dr. Instituição:

Julgamento: Assinatura: 
Aos meus pais - base de tudo, que foram a fonte de amor incomensurável que me possibilitou chegar com a mente quieta, a espinha ereta e o coração tranquilo até aqui. 


\section{AGRADECIMENTOS}

Fazer um trabalho de mestrado na São Francisco foi a realização de um sonho para mim. Poder aprofundar em um estudo acadêmico aquilo que mais me fascina - o potencial das políticas públicas de melhorar a vida da população menos favorecida do Brasil - foi uma oportunidade ímpar.

Se eu consegui concluir essa trajetória, sem dúvida, meu primeiro agradecimento é destinado ao meu orientador, Diogo Coutinho. Diogo fez muito mais do que "apenas" me guiar nesse difícil processo de pesquisa, com suas leituras atentas e orientação próxima para que eu tentasse extrair o melhor possível de cada página escrita. Ele foi também um constante instigador da minha curiosidade intelectual e, quando mais precisei, a fortaleza que me ajudou, com suas sempre carinhosas palavras de estímulo, a me manter em pé para finalizar esse trabalho.

Agradeço também a oportunidade de ter trocado importantes inquietações acadêmicas com o grupo de orientadas e orientados do Diogo. Muito do que está nessa dissertação eu devo aos insights recebidos no DEF naquelas segundasfeiras de manhã ao longo desses últimos três anos, assim como nos inúmeros eventos do grupo de Direito e Políticas Públicas da FDUSP.

Agradeço aos professores Caio Santo Amore e Maria Rita Loureiro pela imprescindível ajuda que me deram com seus apontamentos na banca de qualificação. Ao Caio, em particular, agradeço por ter continuado a colaborar comigo ao longo deste último um ano e meio que nos conhecemos, sendo importantíssimo em momentos-chave da pesquisa como na formulação do roteiro de entrevistas aplicado.

À Hellen, em quem projeto meus sonhos de calouro, obrigado por toda a colaboração nas detalhadas pesquisas das intrincadas legislações e editais do Minha Casa, Minha Vida.

Aos gestores públicos municipais de hoje e de ontem que possibilitaram uma compreensão do Minha Casa, Minha Vida muito além dos textos legais e artigos acadêmicos. Celso Carvalho, Geraldo Juncal, João Whitaker, Marcia Terlizzi, Mario Reali, Ricardo Pereira Leite e Tereza Herling, vocês foram essenciais para minha 
dissertação e para a mudança de vida de inúmeros de paulistanos que necessitavam de um teto.

Agradeço aos sonhadores de Brasília, com quem compartilhei a maravilhosa experiência de tentar mudar o mundo a partir do governo federal com apenas vinte e poucos anos. Duda (minha irmã adotiva candanga), Ric e Cla (almas gêmeas mineiras), Carol e Mario (terroristas zuretas), Carla, Celina, Lica, Felipe Freitas, Flavinho, Gabi, Gui Almeida, Gui Moraes-Rego, Liana, Lobo, Lu, Maca, Marcio, Mau, Du e Vlad (companheiros inesquecíveis de Triathlon), Lang (minha atenta revisora), Nath Ribeiro, Polly, Beta, Sassá, Tati, Thandara, Thor, Valessio, Renato, Gabs, Valdo, Beto, Gui Paiva, Marco, Dino, Paquito e Felipe De Paula, nem os golpes serão capazes de aplacar nossa crença de tentar fazer um país mais justo através do trabalho, samba, cerveja e ideais.

Aos amigos que o XI de Agosto me trouxe, ontem e hoje, é certo que tem uma pitada das nossas longas discussões políticas como pano de fundo desse trabalho. Dedé, Ale, Rapha, Sté, Silas, Chico, Gui e Ivan é uma delícia compartilhar minha trajetória há tantos anos com vocês.

Aos Ping's - Dé, Augusto, Caio, Ana Carol, Tomás, Igor, Rita, Vivi, Bruna obrigado por serem uma enorme fonte de diversão para mim nos momentos de tensão que percorri ao longo desse mestrado.

Aos meus amados Ga, Lu, Ne, Dani e Vivi, obrigado por compreenderem as ausências, me apoiarem nos momentos mais difíceis e serem, desde aquela fatídica SEREC, meus companheiros inseparáveis. Dos choros às grandes vitórias, dos Jurídicos nos restaurantes, passando pelos réveillons em Boituva e carnavais no Rio de Janeiro, até as intermináveis risadas nas longas noites no "cativeiro judaico", vocês são um dos pilares da minha vida.

À minha família materna, representada pelos meus avós Bernardo e Lea e pela minha irmã de coração desde a maternidade, Bru, e à minha família paterna, representada pela minha avó Clara e meus tios Fabio e Raquel, obrigado por serem uma fonte inesgotável de carinho e cuidado.

À Cida e à Gabi, minhas companheiras amadas nos momentos de isolamento para escrita dessa dissertação em Boituva, obrigado pelo carinho e 
cuidado que sempre tiveram comigo. Se terminei essa dissertação, devo muito a companhia de vocês.

À Marina, obrigado por ser minha companheira de todas as horas. Sem sua revisão atenta, sua ajuda nos momentos de trava na escrita e sua incomensurável paciência para aguentar meus dias mais difíceis, é certo que não teria chegado ao fim desse trabalho. Além disso, obrigado por me dar o brilho nos olhos que só os apaixonados têm ao acordar.

Aos meus pais Lilian e Israel e à minha irmã Renata, agradeço por serem essa fonte incondicional de amor, apoio e compreensão. A sorte de ter vocês na minha vida, de maneira tão próxima, me faz entender a dimensão do que é ser abençoado. Se consegui algo na vida, não há dúvidas que devo isso a vocês. Obrigado, com todo o meu coração. 
A receita é política. Combater a especulação imobiliária com regulação de mercado, tirar o controle da política urbana das mãos das grandes empreiteiras e desenvolver uma estratégia de desapropriação que recupere a capacidade do poder público de planejar a política habitacional. Esses são importantes passos para quem quiser de fato acabar com as ocupações urbanas no Brasil. Será que todos estão dispostos a defendê-los? BOULOS, Guilherme. 2015, p. 19 


\section{RESUMO}

O objetivo deste trabalho é analisar como as modalidades do Programa Minha Casa, Minha Vida (MCMV) destinadas à população que ganha entre zero e três salários mínimos (Faixa 1) foram implementadas no Município de São Paulo. A partir de autores que analisaram a execução do MCMV no país, o início do trabalho é destinado a justificar os motivos de se realizar uma pesquisa sobre uma política pública habitacional federal nos limites de um município, contextualizando relevantes desafios da coordenação interfederativa no Brasil, com particular interesse nessa política setorial. Em seguida, passa-se à descrição do desenho do programa MCMV, cujas diretrizes gerais são estabelecidas pela União. Nessa parte, serão apresentados os papéis do direito na definição dos objetivos, do arranjo institucional e das ferramentas jurídicas do MCMV Faixa 1, destacando também as alterações relevantes por que o programa passou ao longo de quase uma década de existência. Posteriormente, será detalhado como se deu a incorporação do MCMV Faixa 1 à política habitacional do Município de São Paulo. Dialogando com a literatura que debate mecanismos de inovação nas políticas públicas, a parte final do trabalho será destinada a indicar quais foram as oportunidades geradas com o lançamento do MCMV para o provimento de habitação de interesse social na cidade e as dificuldades de implementação de um programa desenhado a partir do governo federal pela maior Prefeitura do país. No capítulo destinado à análise de São Paulo, serão destacadas inovações que surgiram em decorrência dos principais entraves de execução do MCMV Faixa 1 na cidade e que foram viabilizadas majoritariamente através de adaptações jurídicas: a alteração de regulações do Ministério das Cidades, garantindo a verticalização dos empreendimentos para baratear proporcionalmente o valor do terreno por unidade habitacional; a criação de um "banco de terras municipal" por meio de desapropriações ou doação de terrenos públicos, o que serviu como contrapartida aos subsídios federais do programa; aprimoramentos no licenciamento dos empreendimentos que contaram com alterações legislativas para tornar mais efetiva a máquina burocrática na liberação de habitações de interesse social; a utilização de instrumentos urbanísticos previstos no Estatuto da 
Cidade e o uso da tecnologia da informação para melhorar o cadastro de beneficiários na cidade.

Palavras-chave: Minha Casa, Minha Vida Faixa 1. Política Habitacional. Direito e Políticas públicas. Coordenação interfederativa. 


\begin{abstract}
This dissertation focuses on how the main housing policy program in Brazil, Minha Casa, Minha Vida's (MCMV), was implemented in the city of São Paulo, most specifically the subprograms aimed at the lowest income demographic (Faixa 1). Using research that analyzed MCMV in Brazil, one of the introduction's main objectives is to justify the purpose of researching a federal housing program at the city level, highlighting relevant challenges of the inter-federal coordination in this area. The second chapter aims to describe the general aspects of the federal regulation of MCMV. In this part, the policy's objectives, institutional arrangement and juridical tools are analyzed. It also emphasizes the changes of MCMV through almost a decade of its existence. The third chapter focuses on the implementation of MCMV Faixa 1 and the way the program relates to São Paulo's housing policies. In dialogue with authors that study innovation in public policy, the final part of the dissertation sheds light to the difficulties and innovations that derived from the implementation of a federal housing program in the country's biggest city. In this chapter, several innovations of the implementation of MCMV Faixa 1 in São Paulo, which are usually law-related changes, will be presented. These include changes in Ministry of Cities' regulations to allow the verticalization of buildings in order to reduce residential unit's land prices; the creation of a municipal land bank through expropriation and donations of public areas in exchange to federal subsidies from MCMV; improvements in projects licensing by changing the administrative structure of the cities' agencies; the use of urban planning tools from the City Statute (Estatuto da Cidade - Law 10.257/2001); and the use of information technology (IT) to improve the enrollment of potential beneficiaries in São Paulo.
\end{abstract}

Keywords: Minha Casa, Minha Vida Faixa 1. Housing policy. Law and public policy. Interfederal coordination. 


\section{LISTA DE SIGLAS}

BB - Banco do Brasil

BNDES - Banco Nacional de Desenvolvimento Econômico e Social

BNH - Banco Nacional de Habitação

CBIC - Câmara Brasileira da Indústria da Construção

CEF - Caixa Econômica Federal

CET - Companhia de Engenharia de Tráfego

$\mathrm{CMH}$ - Conselho Municipal de Habitação

COHAB - Companhia Metropolitana de Habitação

EMI - Exposição de Motivos Interministerial

FAR - Fundo de Arrendamento Residencial

FDS - Fundo de Desenvolvimento Social

FGTS - Fundo de Garantia por Tempo de Serviço

FMH - Fundo Municipal de Habitação

FNHIS - Fundo Nacional de Habitação de Interesse Social

FUNDURB - Fundo de Desenvolvimento Urbano

HABITAT III - Terceira Conferência das Nações Unidas sobre Moradia e Desenvolvimento Urbano Sustentável

HIS - Habitação de Interesse Social

HMP - Habitação de Mercado Popular

IBGE - Instituto Brasileiro de Geografia e Estatística

IPEA - Instituto de Pesquisa Econômica Aplicada

LPUOS - Lei de Parcelamento Uso e Ocupação do Solo (Zoneamento)

MCid - Ministério das Cidades

MCMV - Minha Casa, Minha Vida

MCMV-E - Minha Casa, Minha Vida - Entidades

MF - Ministério da Fazenda

MPOG - Ministério do Planejamento, Orçamento e Gestão

MTST - Movimento dos Trabalhadores Sem Teto

OODC - Outorga Onerosa do Direito de Construir

OU - Operação Urbana

OUC - Operação Urbana Consorciada

PAC - Programa de Aceleração do Crescimento

PCS - Programa Crédito Solidário

PDE - Plano Diretor Estratégico

PIB - Produto Interno Bruto

PLHIS - Plano Local de Habitação de Interesse Social

PMH - Plano Municipal de Habitação

PNHR - Programa Nacional de Habitação Rural

PNHU - Programa Nacional de Habitação Urbana 
RMSP - Região Metropolitana de São Paulo

SEHAB - Secretaria Municipal de Habitação de São Paulo

SEL - Secretaria Municipal de Licenciamento

SMDU - Secretaria Municipal de Desenvolvimento Urbano

SMUL - Secretaria Municipal de Urbanismo e Licenciamento

SMT - Secretaria Municipal de Transportes

SNHIS - Sistema Nacional de Habitação de Interesse Social

SVMA - Secretaria Municipal do Verde e Meio Ambiente

ZEIS - Zona Especial de Interesse Social 


\section{LISTA DE FIGURAS}

Figura 1 - Papel do MCMV Faixa 1 nas políticas habitacional e urbana................................ 34

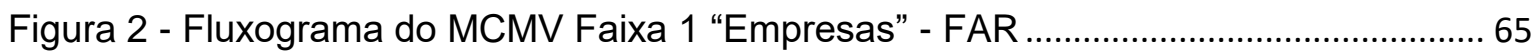

Figura 3 - Fluxograma MCMV Faixa 1 "Empresas" - Doação de terreno público................. 66

Figura 4 - Fluxograma do MCMV Faixa 1 "Entidades" - FDS ……...................................... 73

Figura 5 - Dados da Produção de HIS por tipo de produção entre 1970-2008 ..................... 95

Figura 6 - Unidades produzidas pelo Município e contratadas pelo Estado e pela União entre 2000 até 2008 (até 5 salários mínimos) ..................................................................... 95

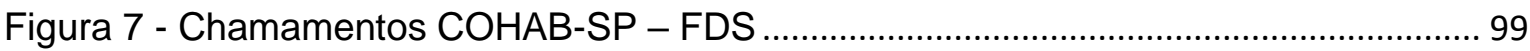

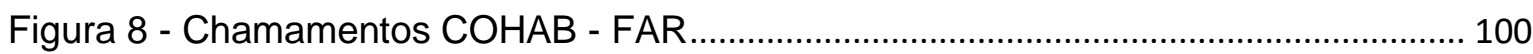

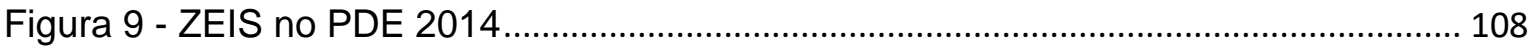

Figura 10 - Destinação de área construída para HIS por tipo de ZEIS (LPUOS 2004 vs

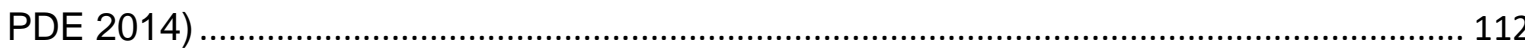

Figura 11 - Funcionamento da Cota de Solidariedade ....................................................... 118

Figura 12 - Comparação Critérios de Priorização de Beneficiários de São Paulo ............ 125

Figura 13 - Critérios de Priorização - Resolução CMH 61/2014 …..................................... 126

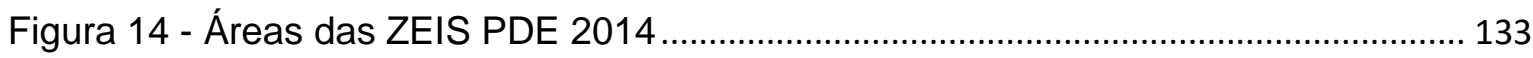

Figura 15 - Comparação do número de HIS na modalidade "Entidades" no Brasil.......... 135 


\section{LISTA DE GRÁFICOS}

Gráfico 1 - Número de domicílios no país (em milhões), déficit habitacional (em milhões) e componentes do déficit (em mil) 53

Gráfico 2 - Contratações do Programa Crédito Solidário (PCS) …….................................... 77

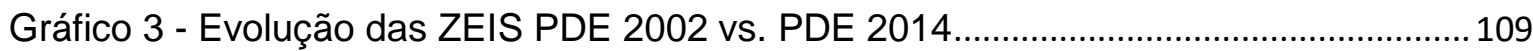

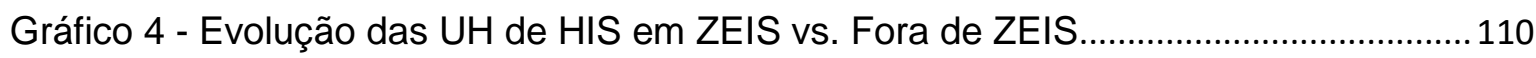

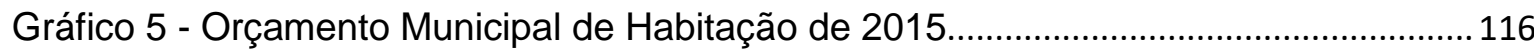

Gráfico 6 - Evolução de contratações MCMV Faixa 1 em São Paulo..................................... 138 


\section{SUMÁRIO}

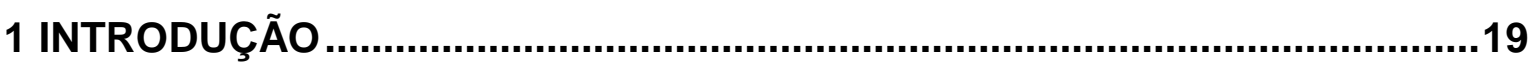

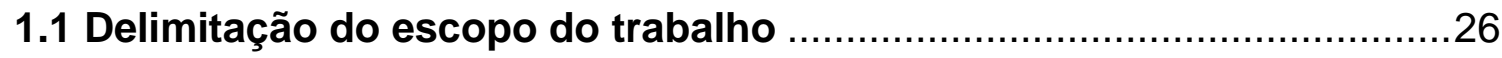

1.2 Minha Casa, Minha Vida Faixa 1 e os desafios da coordenação interfederativa

1.3 Minha Casa, Minha Vida Faixa 1 em São Paulo e as inovações

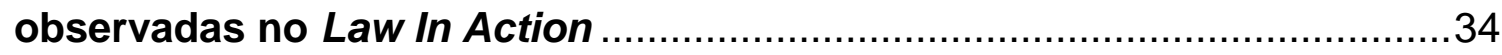

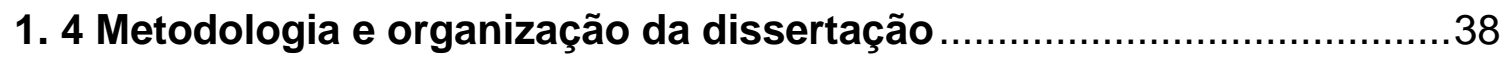

20 DESENHO FEDERAL DO MINHA CASA, MINHA VIDA FAIXA $1 \ldots \ldots \ldots \ldots . . . . . .43$

2.1 Objetivos do Minha Casa, Minha Vida Faixa 1 ......................................48

2.2 Arranjo institucional do Minha Casa, Minha Vida Faixa 1 ....................57

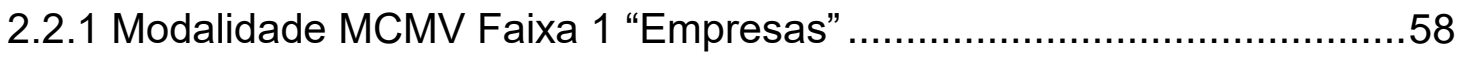

2.2.2 Modalidade MCMV Faixa 1 "Entidades" ...............................................68

2.3 Ferramentas do Minha Casa, Minha Vida Faixa 1 .................................73

3 A IMPLEMENTAÇÃO DO MINHA CASA, MINHA VIDA FAIXA 1 NO MUNICÍPIO DE SÃO PAULO

3.1 A questão fundiária e a formação de um banco de terras público .........88

3.1.1 A complementação financeira do Estado e Município ao subsídio federal (o "20/20") 89

3.1.2 O Banco de Terras Municipal .93

3.1.3 A verticalização dos empreendimentos do MCMV Faixa 1 - o caso dos elevadores. 102

3.2 Instrumentos urbanísticos relevantes ………................................105

3.2.1 Zonas Especiais de Interesse Social ...............................................107

3.2.2 Vinculação do FUNDURB e Cota de Solidariedade ............................114

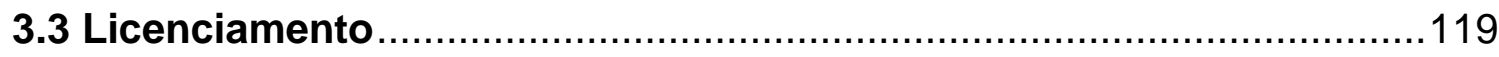




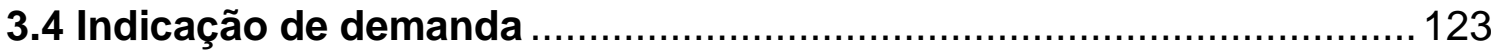

3.4.1 O cadastro de beneficiários.............................................................. 128

3.4.2 A Demanda Fechada .............................................................. 132

3.5 Minha Casa, Minha Vida “Entidades” em São Paulo............................. 134

3.60 alinhamento político importa? ...................................................... 137

4 Conclusão

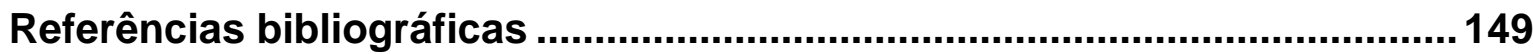

ANEXO 1 - Atos Normativos no âmbito federal sobre o MCMV Faixa 1 - FAR (excluindo regulamentação da CEF) .............................................................165

ANEXO 2 - Atos Normativos no âmbito federal sobre o MCMV Faixa 1 - FDS (excluindo regulamentação da CEF) ..............................................................175

ANEXO 3 - Termo de Consentimento Entrevista.......................................... 187

ANEXO 4 - Roteiro de Entrevista Semiestruturada com Gestores Municipais 


\section{INTRODUÇÃO}

O programa Minha Casa, Minha Vida foi idealizado pelo governo federal como uma medida anticíclica de resposta à crise financeira de 2008/2009, com o objetivo de manter os níveis de renda e emprego no país ${ }^{1}$ por meio da produção de novas unidades habitacionais.

A formulação do programa lançado em março de 2009 coincidiu com o período mais agudo do impacto econômico da crise internacional dos subprimes sobre o Brasil. Segundo dados do Instituto Brasileiro de Geografia e Estatística (IBGE), ${ }^{2}$ após 9 trimestres de crescimento do Produto Interno Bruto (PIB) a taxas superiores a 4,5\% (com picos de até $7 \%$ ), a economia brasileira sofreu uma forte desaceleração, tendo entrado em uma recessão técnica ${ }^{3}$ já a partir do segundo semestre de 2009. Com a redução do PIB, o índice de desemprego, que beirava a taxa de $7 \%{ }^{4}$ nos meses do segundo semestre de 2008, chegou a atingir 9\% em março de 2009.

Além dessa conjuntura crítica, ainda antes da chegada da crise, a partir do fim do primeiro mandato do governo Luiz Inácio Lula da Silva (2006), o Brasil passava por uma redefinição do papel do Estado na economia, com o aprofundamento de medidas intervencionistas e de expansão do gasto público em áreas consideradas estratégicas para a manutenção de um "desenvolvimento acelerado e sustentável" ${ }^{5}$

\footnotetext{
1 "De fato, diante do cenário de crise financeira mundial com o recrudescimento de seus impactos negativos sobre a atividade econômica, renda e nível de emprego do País é premente a necessidade de adocão de medidas de natureza anticíclicas no curto prazo, principalmente aquelas que possam garantir a melhoria da qualidade de vida da população de baixa renda e a manutenção do nível de atividade econômica." Trecho da Exposição de Motivos da Medida Provisória n 459, de 25 de março de 2009, que deu origem à primeira fase do programa Minha Casa, Minha Vida (MCMV).

2 Série histórica do Produto Interno Bruto brasileiro: https://seriesestatisticas.ibge.gov.br/series.aspx?vcodigo=ST12 . Último acesso em 04 de novembro de 2017.

3 O termo "recessão técnica" significa que uma economia teve crescimento negativo por dois trimestres seguidos.

4 Para acesso aos dados mensais de emprego, ver: http://www.ipeadata.gov.br/exibeserie.aspx?serid=38401. Último acesso em 04 de novembro de 2017.

${ }^{5}$ A expressão "desenvolvimento acelerado e sustentável" foi retirada da descrição do Programa de Aceleração do Crescimento do site do Ministério do Planejamento. Programa-síntese dessa retomada do ativismo estatal na economia, o PAC é apontado como "a retomada do planejamento e execução de grandes obras de infraestrutura social, urbana, logística e energética do país, contribuindo para o
} 
Exemplos dessa retomada do ativismo estatal ${ }^{6}$ podem ser observados na troca do comando do Ministério da Fazenda, com a substituição do ministro Antonio Palocci, ${ }^{7}$ mais fiscalista, por Guido Mantega, mais desenvolvimentista; no lançamento do Programa de Aceleração do Crescimento (PAC) em janeiro de $2007 ;^{8}$ na queda gradual da taxa de juros ${ }^{9}$ a partir do começo de 2006; na política de valorização do salário mínimo acima da inflação potencializada, a partir do início do segundo mandato do presidente Luiz Inácio Lula da Silva; e na expansão dos desembolsos do Banco Nacional de Desenvolvimento Econômico e Social (BNDES), ${ }^{10}$ implicando um substancial incremento do papel do Banco de Desenvolvimento na economia brasileira, especialmente no setor de infraestrutura.

Nesse contexto, que somava a necessidade específica de uma medida anticíclica contra a crise a um fenômeno mais estrutural de ampliação do papel do Estado na economia, é que o governo federal optou por lançar um pacote de

seu desenvolvimento acelerado e sustentável". Acesso pelo link http://www.pac.gov.br/sobre-o-pac . Último acesso em 3 de julho de 2016.

${ }^{6}$ Esse processo de retomada do ativismo estatal também foi notado por Trubek, Coutinho e Schapiro que identificaram o segundo governo Luiz Inácio Lula da Silva como um aprofundamento do fenômeno de um Novo Ativismo Estatal ("New State Activism - NSA") no país: "Although Lula's first administration took cautious steps toward state activism, interest in a stronger role for the state grew during Lula's second term (2006-10). In this period, NSA gained appeal, importance, and political support from industrialists, unions, intellectuals, and academics. Brazilian economist Antonio Barros de Castro suggests that the Brazilian elite realized that it needed to 'deal with China'." (TRUBEK, COUTINHO e SCHAPIRO, 2012, p. 296)

${ }^{7}$ A saída de Antonio Palocci do comando do Ministério da Fazenda esteve relacionada ao escândalo da quebra de sigilo bancário do caseiro Francenildo Santos Costa, um desdobramento da CPI dos Bingos. Apesar de não ter sido resultante de um desejo explícito de reorientação da política econômica, a troca de Palocci pelo então presidente do BNDES, Guido Mantega, significou, sem dúvida, a ascensão de um ministro da Fazenda mais alinhado com ideias de maior intervenção estatal na economia. Sobre a alteração do perfil ministerial decorrente da troca e seus impactos, ver SINGER (2012, p. 146-154).

8 Sobre o conjunto de iniciativas da primeira fase do PAC, ver apresentação do Ministério da Fazenda de janeiro de 2007 em http://www.fazenda.gov.br/centrais-deconteudos/apresentacoes/2007/r220107-pac-pdf29 . Último acesso em 03 de julho de 2016.

${ }^{9}$ A taxa SELIC caiu do patamar de $18 \%$ ao ano em dezembro de 2005 para 10,25\% ao ano em abril de 2009, pouco mais de um mês depois do lançamento do Minha Casa, Minha Vida. Informação disponível em http://www.bcb.gov.br/Pec/Copom/Port/taxaSelic.asp. Último acesso em 03 de julho de 2016

10 Apenas entre 2005 e 2010, o BNDES expandiu seus desembolsos anuais de $R \$ 46,8$ bilhões de reais para $R \$ 168,4$ bilhões de reais, representando um aumento de mais de $200 \%$ nos valores em apenas cinco anos. Para a evolução dos desembolsos do banco público, ver http://www.bndes.gov.br/SiteBNDES/bndes/bndes pt/Institucional/BNDES Transparente/Estatistica s Operacionais/\#desembolsos. Último acesso em 03 de julho de 2016. 
estímulos à construção civil, por considerar o setor estratégico para a retomada do crescimento. ${ }^{11}$

O "pacote habitacional" - nome que a imprensa havia conferido ao conjunto de medidas de estímulo ainda em gestação pelo governo no primeiro trimestre de 2009 - teve sua primeira formulação feita entre representantes do setor da construção civil ${ }^{12}$ e a equipe econômica do segundo governo Luiz Inácio Lula da Silva (ROLNIK, 2015, p. 300-303). Nessa fase, antes de passar pelo núcleo político do governo, o enfoque central do "pacote" estava em viabilizar, por meio de bancos públicos federais, a expansão do crédito habitacional para a classe média, objetivando reaquecer o mercado imobiliário nacional.

Após embates com as áreas sociais do governo ${ }^{13}$ e a pressão de movimentos sociais (ROLNIK, 2015, p. 302; RODRIGUES, 2013, p. 54-60), foram incluídos, entre as medidas de estímulo, os subsídios quase integrais à moradia para a população com renda familiar entre zero e três salários mínimos. Essa medida foi chamada posteriormente de Faixa 1 do programa e desde então é voltada ao público-alvo que concentra o déficit habitacional no Brasil. ${ }^{14}$

Essa ampliação, nas palavras de Bonduki (2014, p. 118), "transformou uma ação que originalmente tinha apenas um caráter anticíclico em um programa com conteúdo mais social", nos moldes do que havia sido formulado no Plano Nacional de Habitação. ${ }^{15}$ Do referido Plano - documento responsável por "formular uma

\footnotetext{
11 Em fala na 17ª Feira Internacional da Indústria da Construção - Feicon, dois dias após o lançamento do MCMV, o então presidente Luiz Inácio Lula da Silva afirmou: "(...) o setor da construção civil que ficou 20 anos 'morgando' nesse país possa agora exercer o papel de setor econômico que mais pode ativar a economia do país." (PAIXÃO, 2009).

12 Rolnik (2015, p.300) aponta que "os empresários atingidos, liderados pela GAFISA e apoiados pela $\mathrm{CBIC}$, passam a intensificar o lobby junto à Fazenda para implementar um "pacote habitacional" nos moldes do programa mexicano, que, por sua vez, havia sido inspirado no modelo chileno". Os programas mexicano e chileno eram, assim como o MCMV, fortemente dependentes de subsídios estatais e possuíam grande protagonismo das construtoras e incorporadoras nacionais na viabilização de moradias populares.

${ }^{13}$ Liderados especialmente pela Secretária Nacional de Habitação do Ministério das Cidades, Inês Magalhães (BONDUKI, 2009, p. 12).

${ }^{14} \mathrm{O}$ déficit é essencialmente (85,7\% dos domicílios) um problema urbano que se concentra em uma população com renda de até 3 salários mínimos (83,4\% em 2013 e 83,9\% em 2014) (FUNDAÇÃO JOÃO PINHEIRO, 2016, p. 28-30).

15 Nas palavras de Maria Rita Loureiro: "o PlanHab foi elaborado pela Secretaria Nacional de Habitação (SNH) do Ministério das Cidades, a partir de consulta à sociedade civil, aos estados e municípios por meio da Conferência Nacional das Cidades. Este processo ocorreu durante mais de dois anos, mobilizando vários atores na sociedade e no Estado e gerando debates entre grupos de
} 
estratégia de longo prazo para equacionar as necessidades habitacionais do país" (MINISTÉRIO DAS CIDADES, 2009, p. 8), o MCMV incorporou apenas elementos do eixo financeiro ao ampliar muito os subsídios ${ }^{16}$ destinados a viabilizar a aquisição de propriedade privada pela população de mais baixa renda.

No entanto, o MCMV deixou em segundo plano disposições referentes à política urbana e fundiária a ser executada pelos Municípios, bem como a adoção de soluções que não estivessem relacionadas à construção de novas unidades habitacionais, além de ter criado uma via alternativa de financiamento que era apartada do Sistema Nacional de Habitação de Interesse Social ${ }^{17}$ (Lei 11.124, de 16 de junho de 2005), baseado em uma lógica mais ampla de diagnóstico da situação

várias regiões do país, com o acompanhamento direto de membros do Conselho Nacional das Cidades e do Conselho Gestor do Fundo Nacional de Habitação de Interesse Social (FNHIS). Como indicou a SNH na ocasião de seu lançamento, o plano representou a retomada do planejamento do setor habitacional no Brasil ao estabelecer 'estratégias de longo prazo para solucionar as necessidades habitacionais do país, presentes e futuras, universalizando o acesso à moradia digna para todo cidadão brasileiro' (Plano Nacional de Habitação, p. 5). Na verdade, a elaboração do PlanHab representou importante momento de capacitação para essa equipe da $\mathrm{SNH}$, porque para sua confecção foram feitos numerosos estudos, diagnósticos e projeções de demanda por habitação para a população de baixa renda, a par de análises de temas como a precificação dos produtos, cálculos de necessidade de subsídios etc. Conforme apontaram entrevistados, além de definir metas para atender o deficit habitacional para moradias subsidiadas (23 milhões até 2023), as políticas propostas no PlanHab procuraram igualmente superar a tradição de produção estatal de moradia, à maneira do $\mathrm{BNH}$ e das Companhias de Habitação Popular (COHABs) e evitar erros de outras experiências como a do México, no governo Vicente Fox, que criou subsídios para a população de baixa renda sem, entretanto, conectar a construção habitacional a projetos urbanísticos de transporte e serviços de educação e saúde" (LOUREIRO, 2014b, p. 119-120).

${ }^{16}$ Bonduki atestou a relevância do vulto de recursos previsto ao MCMV da seguinte forma: "Nessa conjuntura, o governo decidiu aplicar $\mathrm{R} \$ 26$ bilhões em subsídios para unidades novas, valor que somou ao que já estava previsto pelo PAC para a urbanização de assentamentos precários. Assim, adotou-se, na prática, o cenário de aporte de recursos mais otimista proposto pelo PlanHab, alcançando um investimento aproximado de $2 \%$ do Orçamento Geral da União em subsídios habitacionais, patamar que, de acordo com a estratégia prevista originalmente, deveria levar alguns anos para ser atingido." (BONDUKI, 2014, p. 118.)

17 Segundo o Instituto Polis, o SNHIS, "criado pela Lei Federal no 11.124/2005, é fruto do 1ㅇ Projeto de Lei de iniciativa popular apresentado após a Constituinte. O SNHIS é um sistema nacional, descentralizado e democrático que unifica as políticas de habitação social e fomenta a produção de habitação de qualidade para população de baixa renda, através da ação conjunta dos seus diversos agentes promotores" (POLIS, 2007, p. 3). O Sistema criava um complexo arranjo que pressupunha financiamento federal (por meio do Fundo Nacional de Habitação de Interesse Social-FNHIS), de um lado, e planejamento municipal para recebimento desses recursos, de outro. Para a atuação de planejamento municipal, o Ministério das Cidades ficaria responsável por ajudar com assistência técnica para criação de instâncias de participação social, como conselhos municipais de habitação, e formulação de Planos Locais de Habitação de Interesse Social, que serviriam tanto para diagnosticar questões como o déficit habitacional, como para mensurar as necessidades financeiras e melhores formas de alocação desses recursos. Para uma breve descrição do arranjo e funcionamento do SNHIS e do FNHIS, ver Krause, Balbim e Neto (2013, p.10-16). 
habitacional, de proposição de diferentes formas para sua solução e fortes mecanismos de participação social.

A politização ${ }^{18}$ do caráter mais social que o "pacote" ganhou em sua fase final de formulação foi maximizada por declarações do então presidente Luiz Inácio Lula da Silva e de sua ministra chefe da Casa Civil, Dilma Rousseff, ${ }^{19}$ que prometeram, um mês antes do lançamento do MCMV, a construção de 1 milhão de casas populares (BONDUKI, 2008, p. 8), a serem entregues em um prazo não definido inicialmente. ${ }^{20}$

Por fim, em seu desenho final, para as diversas faixas de renda beneficiadas pela medida, a ideia era viabilizar o "sonho da casa própria", fosse por meio de subsídios do Orçamento Geral da União a quem ganhava até três salários mínimos ou pela facilitação do crédito do Fundo de Garantia do Tempo de Serviço (FGTS) para as construtoras e os beneficiários com renda familiar de até dez salários mínimos.

Essas soluções adotadas pelo programa, que garantiram, ao mesmo tempo, casas subsidiadas aos mais pobres e a expansão de um potencial mercado consumidor de classe média às incorporadoras, foram capazes de viabilizar uma coalizão que uniu, como poucas vezes na história, ${ }^{21}$ empreiteiras e movimentos sociais de moradia em apoio ao MCMV (KLINTOWITZ, 2016, p.166-167).

Em seu lançamento, em 25 de março de 2009, o "pacote habitacional" deixou de ser uma medida pontual e tornou-se um programa, que foi chamado de "Minha

\footnotetext{
18 O lançamento do MCMV em março de 2009 foi cercado de acusações da oposição de que o governo estaria usando a máquina para promover uma espécie de pré-candidatura da então ministrachefe da Casa Civil, Dilma Rousseff. (GIRALDI, 2009.) O governo usou como estratégia de resposta a indicação de que todos os "bons programas sociais" lançados eram acusados de serem eleitoreiros, reforçando a politização do caráter social do $\operatorname{MCMV}(\mathrm{G1}, 2009$.

${ }^{19}$ Reportagem sobre anúncio do pacote habitacional em encontro nacional de prefeitos, um mês antes da edição da medida provisória de lançamento do programa. (OLIVEIRA, 2009.)

20 "Imaginávamos que fosse possível cumpri-lo em dois anos, mas não tem limite, não tem data. Portanto, ninguém me cobre que vamos fazer 1 milhão de casas em dois anos. A gente não tem que se importar com o tempo. Gostaria que terminasse em 2009. Sei que não dá. Se não der em 2010, que vá para 2011", disse o Presidente Luiz Inácio Lula da Silva na apresentação do pacote habitacional. (D'AMORIM; PERES; IGLESIAS, 2009.)

${ }^{21}$ Danielle Klintowitz (2016, p.178) apontou que a coalizão entre o setor produtivo da construção civil e os movimentos de moradia já vinha sendo ensaiada em outros temas prévios ao MCMV, como no caso da Proposta de Emenda Constitucional (PEC) da moradia digna, que objetivava vincular $2 \%$ do orçamento geral da União a subsídios habitacionais.
} 
Casa, Minha Vida" (MCMV). Ou seja, ao lançá-lo, o governo sinalizou que o programa não seria apenas uma medida anticíclica de combate à crise com recursos limitados, mas sim uma opção de política duradoura adotada para combater o déficit habitacional no país e garantir a facilitação de crédito para aquisição de casa própria por parte da classe média, política a ser incluída continuamente no orçamento do Ministério das Cidades.

Desde então, entre 2009 e 2017, foram contratadas mais de 4 milhões de unidades habitacionais segundo dados do governo (GOVERNO DO BRASIL, 2016), tornando o MCMV a política pública ${ }^{22}$ de provimento habitacional que mais produziu moradias populares no Brasil. ${ }^{23}$

Do ponto de vista econômico, as cifras declaradas também são relevantes: 0 volume de investimento já superou $\mathrm{R} \$ 300$ bilhões de reais ${ }^{24}$ (aproximadamente $5 \%$ do PIB) se considerada a utilização de recursos do Orçamento Geral da União (OGU) e do Fundo de Garantia por Tempo de Serviço (FGTS), além de ter gerado mais de 1 milhão de empregos diretos e indiretos pelo reaquecimento do setor (AGÊNCIA CAIXA DE NOTÍCIAS, 2014).

Se os dados oficialmente divulgados do programa impressionam, existem, contudo, diversas dúvidas sobre os aspectos qualitativos legados pelo MCMV sobre as cidades brasileiras.

Diversos pesquisadores (KRAUSE, BALBIM e NETO, 2013, passim, ROLNIK, 2015, p. 298-314; FIX e ARANTES, 2009, passim; CARDOSO et al, 2013, p. 146159; MARQUES e RODRIGUES, 2013, passim; FERREIRA, 2015, passim) vêm apontando problemas gerados pelo MCMV do ponto de vista da inserção

\footnotetext{
${ }^{22}$ Ao longo de todo o texto, a expressão "política pública" será constantemente utilizada. Para facilitar a compreensão do leitor, estabelece-se, a partir desse momento, que sua definição nesse texto será a dada por Maria Paula Dallari Bucci (2013, cap. 2, sem página - livro eletrônico): "política pública é o programa de ação governamental que resulta de um processo ou conjunto de processos juridicamente regulados".

${ }^{23}$ A título comparativo, o período de maior produção de habitação popular antecedente ao MCMV havia ocorrido durante a existência do Banco Nacional de Habitação (1964-1986), em que foram construídas pouco mais de 2.3 milhões de unidades para o público-alvo de baixa e média renda (BONDUKI, 2012, p. 64).

24 Até o lançamento da $3^{\text {a }}$ fase do MCMV em 2016, o governo havia indicado que o investimento atingira $R \$ 294$ bilhões de reais. (MAIA, 2016.)
} 
urbanística $^{25}$ dos empreendimentos, da tipologia e qualidade dos imóveis, do impacto sobre a renda dos beneficiários, entre outros temas que suscitam dúvidas sobre os potenciais efeitos positivos do programa.

Além disso, esses pesquisadores passaram a questionar se a política não estaria reproduzindo os mesmos problemas de programas passados de provimento de habitações em massa, como na época do Banco Nacional de Habitação. ${ }^{26}$ Nesse período, a produção habitacional ficou marcada por criar vazios urbanos decorrentes da construção de grandes empreendimentos em áreas localizadas nas franjas das cidades, pela desvinculação entre políticas de desenvolvimento urbano e habitacional, pela precariedade das habitações em decorrência da ausência de infraestrutura urbana ao redor dos empreendimentos (esgotamento, luz elétrica, água encanada), pela carência na oferta de equipamentos públicos (escolas, creches, hospitais), serviços e comércio nas regiões em que os imóveis eram implementados, além do baixo padrão de qualidade arquitetônica dos imóveis, seja por sua tipologia ou pela criação de bairros imensos sem identidade (AMORE, 2013, p.30-31).

25 De acordo com Coelho Nisida et al, "A interpretação da ideia de inserção urbana aqui utilizada procura dialogar com a conceituação que a literatura sobre planejamento urbano e políticas habitacionais tem consagrado, considerando, além da mera noção da localização no espaço, a articulação, a integração do objeto com seu contexto urbano e meio físico e os aspectos de acessibilidade a bens e serviços que qualificam a forma como o empreendimento habitacional e seus moradores se relacionam, física e funcionalmente, com a cidade" (COELHO NISIDA et. al, 2015, p. 64). A inserção urbanística dos empreendimentos do MCMV Faixa 1 já foi objeto de trabalho específico de urbanistas vinculados ao LabCidade da USP e ao Instituto de Políticas de Transporte e Desenvolvimento, que chegaram a construir uma ferramenta de avaliação de inserção urbana com objetivo de "oferecer parâmetros objetivos para a avaliação da localização, integração com o entorno e desenho urbano dos empreendimentos, a fim de serem utilizados tanto pelas equipes técnicas de aprovação de projetos nas Prefeituras como por técnicos encarregados pela aprovação dos empreendimentos na Caixa Econômica e Ministério das Cidades". Entre os temas considerados estão oferta de transporte, de equipamentos de comércio e serviços e desenho e integração urbana. Disponível em https://www.itdp.org/wp-content/uploads/2015/03/ITDP-Brasil Ferramenta-deAvalia\%C3\%A7\%C3\%A3o-de-Inser\%C3\%A7\%C3\%A3o-Urbana em-PT vers\%C3\%A3o-WEB.pdf . Último acesso em 04 de novembro de 2017.

26 De acordo com 0 verbete do CPDOC da FGV (disponível em http://www.fgv.br/cpdoc/acervo/dicionarios/verbete-tematico/banco-nacional-da-habitacao-bnh):

"Pela Lei $\mathrm{n}^{\circ}$ 4.380, de 21 de agosto de 1964, foi instituído o Plano Nacional da Habitação e criado o Banco Nacional da Habitação, com sede no Rio de Janeiro. O banco deveria ser o gestor e financiador de uma política destinada a 'promover a construção e aquisição da casa própria, especialmente pelas classes de menor renda', bem como a ampliar as oportunidades de emprego e dinamizar o setor da construção civil. A pedra angular do BNH era o Sistema Financeiro da Habilitação (SFH), que tinha por finalidade principal prover recursos que garantissem a execução do Plano Nacional da Habitação." 
Resumidamente, é possível afirmar que enquanto o programa teve grande adesão por parte de Estados e Municípios em todo o país, como os números do MCMV indicam, é comum o questionamento sobre quão integrada essa produção habitacional está às políticas urbanas dos Municípios brasileiros (DENALDI, 2012, passim; KRAUSE, BALBIM e NETO, 2013, passim).

\subsection{Delimitação do escopo do trabalho}

Conforme se aprofundará no capítulo 2, do ponto de vista da estruturação do programa, o MCMV é subdividido em modalidades que variam de acordo com a renda do beneficiário, ${ }^{27} \mathrm{o}$ tamanho dos municípios em que estão inseridos os empreendimentos e a origem dos recursos destinados às construções.

É relevante entender que, apesar de estar sob a mesma denominação, o Minha Casa, Minha Vida identifica mais uma marca ${ }^{28}$ do que uma política pública uniforme,$^{29}$ na medida em que as modalidades têm objetivos, públicos-alvo, fontes de financiamento e atores distintos em sua fase de implementação.

Essas diferenças, por sua vez, se desdobram em arranjos jurídicos distintos, envolvendo tanto atores diferentes em determinadas situações quanto os mesmos agentes exercendo funções diferentes ${ }^{30}$ a depender de qual subprograma se está tratando. Da mesma forma, na maioria dos casos, as modalidades são reguladas por

\footnotetext{
27 Atualmente existem quatro faixas de renda para os beneficiários. Regulados por Portarias do Ministério das Cidades, os atuais valores máximos por Faixa são os seguintes: Faixa $1-R \$ 1.800,00$ (mil e oitocentos reais); Faixa 1,5-R $\$ 2.600$ (dois mil e seiscentos reais); Faixa $2-R \$ 4.000,00$ (quatro mil reais); Faixa $3-\mathrm{R} \$ 9.000,00$ (nove mil reais).

${ }_{28}$ Expressão usada por Caio Santo Amore $(2015$, p.15) em livro que avaliou a implementação do Minha Casa, Minha Vida em seis estados do país.

${ }^{29}$ Apenas para exemplificar, citam-se as distinções entre as modalidades do Faixa 1 e do Faixa 3, os "extremos" do programa. No primeiro caso, as unidades habitacionais são viabilizadas através de recursos orçamentários, sendo quase integralmente subsidiadas aos beneficiários. O público-alvo da faixa voltada aos mais pobres é majoritariamente considerado como déficit habitacional e essa demanda por moradia passa pelo cadastro de governos estaduais e municipais. Já o Faixa 3 é uma fonte de crédito habitacional, facilitando o acesso da classe média a moradias ofertadas pelo mercado e contando com subsídios modestos aos beneficiários.

30 Os municípios têm o papel de seleção da demanda dos beneficiários nas modalidades destinadas à Faixa 1, enquanto nas Faixas 2 e 3 os interessados (beneficiários) na casa própria buscam os imóveis de maneira semelhante a qualquer outra compra de mercado - com os potenciais consumidores indo direto aos empreendimentos e, posteriormente, buscando o financiamento na Caixa Econômica Federal.
} 
normas (especialmente as infralegais ${ }^{31}$ ) distintas, bem como as ferramentas jurídicas para sua implementação não são as mesmas (i.e. a origem dos recursos do Faixa 1 é o Orçamento Geral da União, enquanto das Faixas 2 e 3 é o FGTS).

Para esta dissertação, interessará apenas a Faixa $1^{32}$ do programa para municípios com mais de 50 mil habitantes, cujo público-alvo é a população com renda familiar de zero a três salários mínimos.

Não tratarei, portanto, das Faixas 2 e 3 porque esses subprogramas possuem desenhos completamente distintos, que, em apertadíssima síntese, estão relacionados a mecanismos privados de oferta de novas unidades habitacionais. Isso significa que a análise dessas modalidades envolveria um estudo do desenho do funcionamento da captação de crédito para construção de novos imóveis pelas empreiteiras e da demanda privada por novas moradias de uma população de classe média, ${ }^{33}$ bem como seus eventuais impactos. ${ }^{34}$

Do ponto de vista da demanda, as Faixas 2 e 3 abarcam potenciais beneficiários que não são o público-alvo majoritário da política habitacional do Estado, por não fazerem parte do déficit. ${ }^{35}$ Trata-se de pessoas que estão buscando

31 Bucci (2002, p. 271-272), ao tratar das funções normativas do Poder Executivo, indica que a utilização desses atos infralegais é um importante instrumento que dota o governo de flexibilidade para implementação de políticas públicas.

32 A partir da 3a fase do programa, lançada em 2016, também há uma faixa chamada de 1,5 - cujas regras se assemelham bastante às da Faixa 1. Esta Faixa será tratada de maneira menos aprofundada ao longo deste trabalho, tendo em vista ser a mais recente e pelo fato de ter uma execução extremamente diminuta em decorrência da crise econômica dos últimos anos no Brasil, fato que será melhor explorado nos capítulos 2 e 3 desta dissertação.

${ }^{33}$ Faz-se uma ressalva sobre essa assertiva. É importante compreender que as faixas do MCMV são iguais para todo o território nacional apesar das diferenças de renda e custo de vida existentes entre regiões distintas no país. Apesar de terem desenhos bastante semelhantes, é muito distinta a capacidade de aquisição de um imóvel, ainda que com graus de subsídio maiores, para uma família que possui renda na parte inferior da Faixa $2(R \$ 2.600$ por mês) e de uma família que possui nível mais próximo da parte superior da Faixa 3 ( $\mathrm{R} \$ 9.000$ por mês).

34 Para uma análise das Faixas 2 e 3 no país, ver Ferreira (2012, p.39-59), que trata esses subprogramas como o "segmento econômico" do MCMV.

35 "A produção do MCMV dirigida à faixa 1 corresponde, grosso modo, àquela que concentra a maior parte do déficit habitacional do país. O déficit, conforme definição adotada pela Fundação João Pinheiro (FJP) (Brasil, 2011), é composto por quatro componentes, a saber: i) precariedade habitacional; ii) coabitação familiar; iii) ônus excessivo com aluguel; e iv) adensamento excessivo em domicílios locados" (LIMA NETO, KRAUSE e FURTADO, 2015, p. 8). É interessante notar que a definição de déficit é multifacetada, pois abrange, ao mesmo tempo, uma dimensão de renda (i.e. ônus excessivo com aluguel, que é o comprometimento de mais de $30 \%$ da renda com moradia) até questões de bem-estar (i.e. adensamento excessivo, que se refere aos casos em que três ou mais indivíduos utilizam o mesmo cômodo). 
"apenas" empreendimentos para aquisição, podendo, de acordo com a sua renda, contar com algum nível de subsídio do governo federal, ofertado via bancos públicos federais no momento da obtenção do financiamento.

Em outras palavras, essas modalidades foram desenhadas para ser, comparativamente, mais parecidas com uma política econômica de estímulo ao consumo e crédito à classe média - como a isenção de Imposto sobre Produtos Industrializados (IPI) para a aquisição de carros novos - do que uma política social focada na base da pirâmide social, que é de interesse do autor. Ou seja, o públicoalvo das Faixas 2 e 3, como regra geral, não constitui o centro da política habitacional de Estados e Municípios.

Quanto aos motivos da escolha de estudar o Faixa 1, estes serão melhor explorados ao longo desta introdução, mas um dos elementos centrais para entender esse recorte decorre do fato de que é nas modalidades desta faixa que se observa o "casamento" entre a implementação das políticas setoriais de habitação por Estados e Municípios e a correspondente coordenação interfederativa de uma das políticas públicas de maior escala atualmente no Brasil.

Isso se dá porque, conforme se demonstrará a seguir, é preciso levar em consideração que a política de habitação de Estados e Municípios é mais ampla do que apenas o provimento de novas habitações, na medida em que envolve políticas de regularização fundiária, aluguel social, reurbanização de favelas, entre outras. E, ainda, que no bojo das políticas de provimento habitacional, o MCMV é apenas uma opção que pode coexistir com outras medidas locais de produção de novas casas.

Reforça-se, ainda sobre esse "casamento", que é inviável que o MCMV Faixa 1 seja implementado sem a atuação ativa dos entes locais. Enquanto nas Faixas 2 e 3, os municípios têm uma participação menor, limitando-se apenas a licenciar os empreendimentos, como em qualquer outro novo prédio na cidade, na Faixa 1, apenas para citar alguns exemplos, aos entes locais foram delegados os papéis de seleção dos beneficiários (demanda do MCMV), a possível doação de terrenos para os empreendimentos e a adoção de instrumentos urbanísticos do Estatuto da Cidade para facilitar a implantação de habitações de interesse social em áreas dotadas de maior infraestrutura urbana. 
Sobre a relevância do papel dos municípios e como o programa federal deve se relacionar com as políticas de desenvolvimento urbano locais, Bonduki fez um apontamento extremamente relevante à época do lançamento do MCMV:

É importante ressaltar que são limitadas as possibilidades do governo federal quanto a garantir uma localização adequada dos projetos se os municípios não estiverem dispostos a isso. Cabe a eles, por meio de seus planos diretores e habitacionais, definir os locais onde é permitida e deve ser estimulada a implantação de novos empreendimentos (BONDUKI, 2009, p. 13, grifos meus).

Diante desse contexto, este estudo almeja investigar como um Município se adapta para incorporar em sua política habitacional local o MCMV Faixa 1 desenhado pela União. Isto é, quais são os desafios e dificuldades que o ente local enfrenta, ao buscar atacar a precariedade ${ }^{36}$ habitacional de sua população mais pobre, incorporando um programa do governo federal que não é pensado para suas necessidades específicas. E, caso existam, que inovações ${ }^{37}$ surgem ao longo dessa implementação.

\subsection{Minha Casa, Minha Vida Faixa 1 e os desafios da coordenação interfederativa}

36 De acordo com o Plano Municipal de Habitação de São Paulo, "o conceito de precariedade habitacional é complexo, e se estrutura a partir de um conjunto grande de condicionantes. Um dos estudos mais consistentes sobre o tema (CEM/Cebrap e Ministério das Cidades, 2007) identifica a precariedade habitacional a partir de dados socioeconômicos dos moradores, como a renda média (geralmente abaixo dos três salários mínimos), os anos de estudo do responsável, a taxa de alfabetização, aos quais se somam dados sobre a qualidade da moradia em si, como o tipo da construção (se de alvenaria ou de madeira), a posse ou não da moradia e do terreno, o número de cômodos, a presença ou não de sanitários, de cozinha. Por fim, analisam-se dados urbanísticos como a presença ou não de rede de esgoto ou fossa séptica, de abastecimento de água e fornecimento de energia elétrica, de lixo coletado. Na prática, são favelas mais ou menos consolidadas, muitas delas assentadas em áreas de risco (de enchente, deslizamento ou incêndio/explosão) ou impróprias (áreas contaminadas, por exemplo), loteamentos periféricos, cortiços" (SEHAB, 2016, p. 7).

37 A definição de inovação no setor público utilizada nesta dissertação será a tradução feita por Cavalcante e Cunha do conceito amplo utilizado pelo relatório do Grupo de Especialistas em Inovação do Setor Público da Comissão Europeia: "a inovação pode ser definida como o processo de geração e implementação de novas ideias com vistas à criação de valor para a sociedade, com foco interno ou externo à administração pública (Comissão Europeia, 2013)." (CAVALCANTE e CUNHA, 2017, p. 15.) 
É comum que, entre os juristas, ao estudar uma política pública em um trabalho acadêmico, os esforços se encerrem após a descrição das atribuições de cada um dos órgãos envolvidos na sua implementação. Nas palavras de Diogo Coutinho:

a discussão sobre os efeitos de leis e de políticas públicas privilegia, entre nós, enfoques e abordagens predominantemente estruturais (em oposição a funcionais), que tendem a ser estáticos, formais ou procedimentais. Exemplos disso são controvérsias e disputas de interpretação envolvendo a observância de regras de competência, a autonomia de órgãos e entes públicos, a legalidade dos atos praticados por autoridades administrativas e as possibilidades e limites da revisão de decisões de política pública pelo Judiciário (COUTINHO, 2010b, p. 5, grifos meus).

Ainda que o trabalho descritivo seja necessário, parece-me que, a partir de uma ótica jurídica, tal abordagem seria menos interessante do que um estudo que observasse a lei em ação, o chamado law in action. ${ }^{38}$ No caso do MCMV Faixa 1 isso significa que, embora relevante, a mera descrição de seu desenho não é suficiente para captar questões centrais da implementação da política pública. Isto é, ao descrever o programa, não se pode pressupor que, automaticamente, cada

\footnotetext{
${ }^{38}$ Coutinho aponta as origens da expressão law in action no debate jurídico, referenciando o professor Roscoe Pound, que cunhou a expressão em um texto no início do século XX: "Para o jurista realista norte-americano Roscoe Pound, o law in the books se distingue do law in action. O primeiro se refere às normas que pretendem governar as relações entre os homens, ao passo que o segundo diz respeito àquelas normas que efetivamente as governam, explica Pound (1910, p.15)" (COUTINHO, 2014b, p. 280). A expressão se relaciona, no limite, a uma análise de como o direito se efetiva na prática, e não de uma mera descrição de como deveria ser. O tema do papel do direito em sua ação cotidiana, entretanto, possui uma longa tradição na sociologia jurídica internacional posterior ao trabalho do autor norte-americano. Para uma visão da evolução do Realismo Jurídico "Legal Realism" norte-americano (fim do século XIX e início do século XX), que se opunha ao formalismo e idealismo vigentes nas universidades daquele país em prol de uma análise mais pragmática e utilitária do direito que incluísse as ciências sociais em sua análise, passando pelo movimento "Law and society" (segunda metade do século XX), que ressaltava a importância de estudos empíricos no direito até o período atual, em que esse movimento passou a priorizar estudos que levassem em conta a dimensão do impacto de raça, gênero, origem, entre outros atributos, ver Sarat (2007). Para uma comparação entre as tradições americana (protagonizada inicialmente por Roscoe Pound, que cunhou a expressão "law in action") e europeia (protagonizada inicialmente por Eugen Ehrlich, que cunhou a expressão "living law") do realismo jurídico, ver Nelken (1984). Para uma visão bastante recente e abrangente do significado do movimento do Novo Realismo Jurídico norte-americano "New Legal Realism", que possui uma preocupação grande com a interdisciplinaridade no estudo dos mais diversos fenômenos e agentes que envolvam questões jurídicas de caráter prático, ver Mertz (2016).
} 
ator desempenhe à perfeição a sua função definida por lei sem que se considerem os retrocessos, impasses e, até mesmo, as inovações geradas pela implementação da política pública no âmbito local.

Em se tratando de um programa desenhado no âmbito da União e sendo o Brasil uma federação complexa, o presente trabalho, ao se utilizar da categoria "coordenação interfederativa", ${ }^{39}$ aproxima-se do exercício empreendido por cientistas políticos (ARRETCHE, 2004; ABRUCIO e FRANCESE, 2007; ABRUCIO, 2010; LOUREIRO et al, 2014b). Afinal, são esses estudiosos que apontam a constante necessidade de equilibrar a implementação de políticas públicas em um país em que o poder central concentra maior volume de recursos e capacidade técnica com a autonomia que um Estado federalista pressupõe para as instâncias locais.

Cabe destacar que, mesmo utilizando uma perspectiva de análise que se aproxima da ciência política, o trabalho se situa no campo do direito, na medida em que é por meio da análise legislativa, de acordos de cooperação e de contratos - ou seja, por intermédio do exame de ferramentas essencialmente jurídicas - que se buscará compreender as dificuldades e inovações na implementação do MCMV Faixa 1 no Município de São Paulo.

Interessa, nesta análise do direito aplicado a uma política pública específica, buscar compreender como as ferramentas jurídicas foram utilizadas, adaptadas ou ressignificadas com o objetivo de viabilizar a ação governamental ${ }^{40}$. Nesse sentido,

39 Lotta define esse processo de coordenação nos seguintes termos: "De modo geral, a coordenação pode ser definida como o processo de criação ou utilização de regras de decisão pelas quais diferentes atores se ocupam coletivamente de um mesmo campo (Ariznabarreta, 2001), o que, no caso das políticas sociais brasileiras, se concretiza com o governo federal normatizando-as e financiando-as e, na maioria das vezes, os governos estaduais e municipais implementando as ações." (LOTTA, 2014, p. 5.)

${ }^{40}$ Ao longo deste trabalho o mote será tentar compreender no âmbito da implementação do MCMV Faixa 1 aquilo que Coutinho indica como sendo a vantagem da compreensão funcional do direito na análise de uma política pública "o ângulo funcional permite que o direito seja tomado, simultaneamente, como uma técnica de escolha de meios jurídicos de políticas públicas, como a análise da adequação desses meios aos fins almejados e como a avaliação dos resultados concretamente alcançados, em termos de efetividade social." (COUTINHO, 2014, p. 63) 
objetiva-se verificar como se deu o uso funcional do direito ${ }^{41}$ para garantir a execução do MCMV Faixa 1.

O empreendimento de pesquisa, entretanto, não é completamente inovador. Trabalhos de outros juristas já estudaram impactos regulatórios da chegada do MCMV Faixa 1 em âmbito local (ACOSTA, 2015), além de ser recorrente o esforço de urbanistas e outros cientistas sociais (CARDOSO et al, 2013; AMORE et al, 2015) na compreensão dos desdobramentos territoriais do programa. O que não é comum é que, a partir de uma lente jurídica, se apresente o desenho do programa de maneira geral e se realize em maior profundidade o estudo de uma localidade específica no momento da implementação do Faixa 1. Quer dizer, são menos frequentes os casos de estudos que esmiuçaram os instrumentos jurídicos - legais, regulatórios, contratuais e de gestão pública - utilizados por uma Prefeitura como a de São Paulo para compreender como o Município lidou com as dificuldades de implementação e superou (ou não) os desafios impostos para a execução da política. É essa a contribuição que este trabalho pretende trazer ao estudo do MCMV.

Tornando menos abstrata a assertiva anterior, quer se investigar, por exemplo, como a diretriz da norma federal do programa que trata da necessidade de utilização dos instrumentos do Estatuto da Cidade ${ }^{42}$ como critério de priorização de recursos do MCMV foi interpretada e implementada por São Paulo. Foram utilizadas as tradicionais Zonas Especiais de Interesse Social (ZEIS) para implementação dos empreendimentos? Algum novo instrumento foi utilizado? Qual? Em suma, quer se entender, de um lado, como a Prefeitura de São Paulo se adaptou, por meio de arranjos jurídicos, para a execução da política diante das diretrizes federais e, de outro, se esses próprios ajustes de alguma forma moldaram o programa federal, dando-Ihe, assim, traços peculiares em cada localidade onde foi posto em marcha.

\footnotetext{
${ }^{41}$ Nesse sentido, pode-se dizer que o trabalho, ainda que no âmbito do estudo de apenas uma política pública, objetiva realizar o que Bucci trata como a busca por "compreender de que modo as formas jurídicas da ação governamental influem, catalisando os anseios e forças da sociedade em direção ao desenvolvimento". (BUCCl, 2013, p. 19-20)

42 Lei Federal no 10.257, de 10 de julho de 2001.
} 
No tocante à escolha do aprofundamento em uma cidade específica, isso decorre do fato de que são abundantes os estudos ${ }^{43}$ que comprovam que não há apenas uma forma de implementação do MCMV Faixa 1, mas centenas. Conforme se mostrará ao longo da dissertação, isso está relacionado ao arranjo federativo brasileiro que, desde a última Constituição, atribuiu na prática o provimento de habitações de interesse social ${ }^{44}$ aos entes locais na medida em que alocou as competências da política urbana aos Municípios. ${ }^{45}$

Resumidamente, esta dissertação parte da premissa que não há, no limite, como expandir os achados da implementação do MCMV Faixa 1 de um município para outros, pois isso pressuporia que um conjunto de elementos muito amplo é suficientemente parecido, como a estrutura fundiária da cidade, sua regulação urbanística (i.e., Plano Diretor e Lei de Zoneamento) e, até mesmo, o desejo político de prefeitos e governadores de buscar recursos federais do MCMV para colaborar com sua política habitacional. Isso não significa, de outro lado, que certas lições extraídas de determinada experiência local não possam ser mapeadas com alguma utilidade para outras cidades se aproximando daquilo que Bucci (2013, sem página - livro digital) chama modelo institucional, isto é, "um determinado padrão de arranjo institucional, passível de aplicação e replicação em modelos semelhantes".

Isso quer dizer que o esforço para entender o MCMV Faixa 1 deve ir do arranjo geral - predominantemente estruturado no âmbito federal - ao impacto territorial, cujo protagonismo é essencialmente municipal, pois são esses entes que detêm um conjunto de instrumentos urbanísticos instituídos na Constituição Federal de 1988 e ampliados ou regulados em leis posteriores.

Desse modo, busca-se compreender uma política de provimento de habitação de interesse social - HIS (MCMV Faixa 1, que é apenas uma das linhas ${ }^{46}$ de uma

\footnotetext{
${ }^{43}$ Apenas para citar alguns, SANTO AMORE (2015, passim), ADAUTO e CARDOSO (2013, passim), KRAUSE, FURTADO e LIMA NETO (2015, passim), MARQUES e RODRIGUES (2013, passim), RODRIGUES (2014, passim), KRAUSE, BALBIM e LIMA NETO (2013).

${ }^{44} \mathrm{Na}$ atual Constituição, de 1988, a competência de "promover programas de construção de moradias e a melhoria das condições habitacionais e de saneamento básico" é uma competência comum a União, Estados e Municípios, de acordo com seu art. 23, inciso IX.

45 Arts. 182 e 183 da Constituição Federal.

${ }^{46}$ Exemplos de outras linhas em São Paulo são a locação social pública ou de mercado, a urbanização de favelas, a regularização fundiária, entre outras possibilidades (SEHAB, 2016, passim).
} 
política habitacional) como algo que idealmente seria integrado à política de desenvolvimento urbano da cidade e que passa por um diálogo interfederativo ${ }^{47}$ entre União e Município, conforme demonstra a figura ilustrativa abaixo:

Figura 1 - Papel do MCMV Faixa 1 nas políticas habitacional e urbana

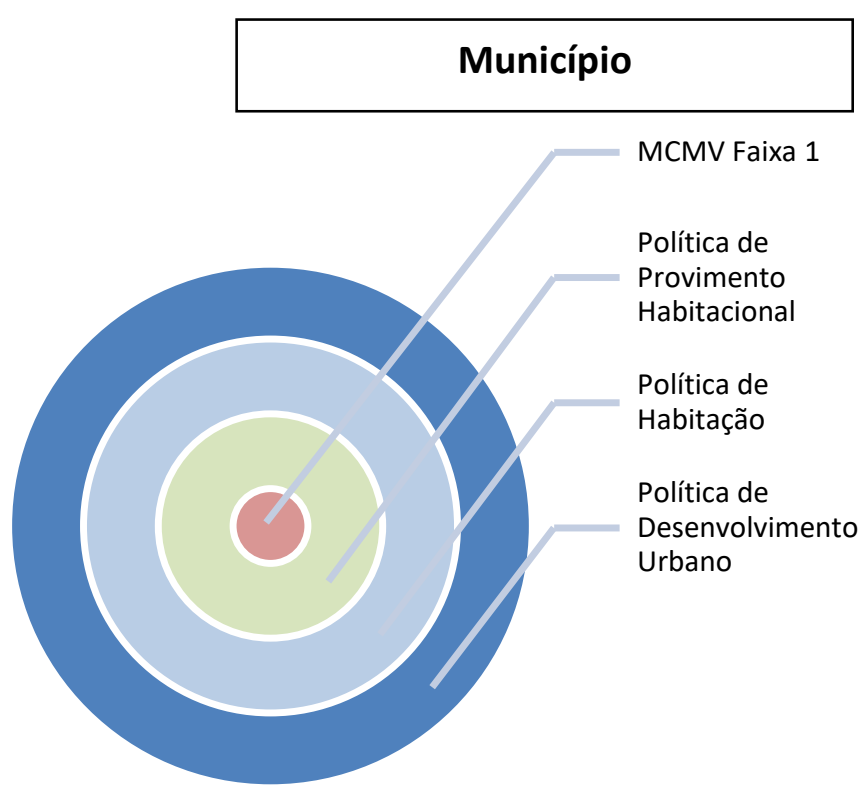

Fonte: elaboração própria.

\subsection{Minha Casa, Minha Vida Faixa 1 em São Paulo e as inovações observadas no Law In Action}

Justificadas a relevância e a pertinência de uma análise territorial do MCMV Faixa 1, é oportuno explicitar os elementos que motivaram o enfoque no Município de São Paulo.

O primeiro ponto de destaque dessa escolha é que a cidade é um caso extremo no que se refere às necessidades de moradia da população - São Paulo

\footnotetext{
47 Na própria política habitacional, esse diálogo interfederativo não se esgota no MCMV, existindo recursos estaduais (i.e., CDHU, SABESP) de provimento de habitação, recursos federais para reurbanização, entre outros.
} 
possui o maior déficit habitacional e inadequação domiciliar absoluto do país, ${ }^{48}$ além da grande dificuldade de acesso à terra para novas construções em decorrência do alto preço do metro quadrado de construção ${ }^{49}$ no município.

Se as demandas habitacionais são relevantes, São Paulo também é um interessante caso de cidade com um longo histórico de uso inovador de instrumentos urbanísticos em seu passado. Muito antes de a Constituição de 1988 exigir que os municípios com mais de 20 mil habitantes organizassem seu desenvolvimento urbano por meio de Planos Diretores, São Paulo já possuía legislação específica de planificação de seu território (o Plano Diretor de Desenvolvimento Integrado de 1971 - Lei Municipal 7.688, de 30 de dezembro de 1971).

Além disso e sem entrar no mérito da forma como foram implementados na cidade, ${ }^{50}$ mais de uma década antes da promulgação do Estatuto da Cidade ${ }^{51}$, 0 Município já havia sido pioneiro no uso de mecanismos de captura da mais-valia urbana, ${ }^{52}$ ou seja, da valorização gerada por investimentos públicos ao proprietário privado. São exemplos: a outorga onerosa do direito de construir ${ }^{53}$ e os certificados

48 O Plano Municipal de Habitação de 2016, baseando-se em dados da Fundação João Pinheiro, estimou em 358.097 domicílios o déficit habitacional e 272.097 domicílios em situação de inadequação (SEHAB, 2016, p.21).

49 Segundo pesquisa FIPEZap finalizada em 2017, São Paulo é a segunda cidade mais cara do país, com custo médio de $R \$ 8.680$ reais para cada $\mathrm{m}^{2}$. (EXAME, 2017.)

${ }^{50}$ Dentre os instrumentos de captação da mais-valia urbana, a implementação das operações urbanas consorciadas na cidade de São Paulo é especialmente alvo de críticas de diversos autores, como Maricato e Ferreira (2002), que apontaram o privilégio dos interesses do mercado imobiliário em detrimento de projetos urbanos mais inclusivos, ou Santoro e Macedo (2014), que trataram das remoções nas operações urbanas consorciadas. Para uma visão mais abrangente das potencialidades do instrumento, ver a tese de doutoramento de Camila Maleronka (2010).

51 Para uma análise das operações urbanas consorciadas no arcabouço legal (especialmente no Estatuto da Cidade) e constitucional, ver Massonetto (2003).

52 Furtado adota o seguinte conceito: "Um entendimento alternativo para o termo "mais-valias fundiárias urbanas" como objeto de recuperação por parte do poder público, é o que remete à valorização experimentada pelos terrenos no processo de urbanização, ou seja, aos acréscimos da renda econômica da terra, usualmente considerados como posteriores ao momento de aquisição da terra por um determinado proprietário. Trata-se, portanto, da valorização territorial ocorrida na constância da propriedade." (FURTADO, In: SANTORO (org.), 2004, p. 57-58.)

53 No atual Plano Diretor Estratégico do Município de São Paulo (art. 340, I da Lei Municipal no 16.050, de 31 de julho de 2014), ficou legalmente estabelecida a subvinculação de $30 \%$ dos recursos do Fundo de Desenvolvimento Urbano para "aquisição de terrenos destinados à produção de Habitação de Interesse Social localizados na Macroárea de Estruturação Metropolitana, e na Macroárea de Urbanização Consolidada e na Macroárea de Qualificação da Urbanização, preferencialmente classificados como ZEIS 3". 
de potencial adicional de construção (CEPAC), ${ }^{54}$ cujos recursos vêm sendo parcialmente subvinculados para construção de HIS na última década. Ainda, no período recente, o Plano Diretor da cidade inovou mais uma vez ao instituir mecanismos para ligar a captura de valor de empreendimentos das áreas mais ricas ao provimento de habitação de interesse social, como a cota de solidariedade. ${ }^{55}$

Do ponto de vista burocrático, ainda que sejam recorrentes as críticas à sua atuação, a mera existência de uma empresa pública municipal com mais de cinquenta anos de experiência no provimento de HIS, como a Companhia Metropolitana de Habitação (COHAB) de São Paulo, chama atenção.

Como derradeiro motivo, pode-se apontar o fato de que nos oito anos de programa, a cidade de São Paulo foi governada por grupos políticos ora alinhados com o governo federal (2013-2016 - Fernando Haddad/Dilma Rousseff e 2017 João Doria/Michel Temer); ora opositores do governo central (2009-2012 - Gilberto Kassab/Luiz Inácio Lula da Silva e Gilberto Kassab/Dilma Rousseff; 2016 - Fernando Haddad/Michel Temer). Tal fato interessa, na medida em que o arranjo institucional ${ }^{56}$ do MCMV Faixa 1 enseja um grau importante de coordenação entre entes municipais e órgãos federais. Em outras palavras, não são viabilizados empreendimentos na

\footnotetext{
${ }^{54}$ Atualmente existem quatro Operações Urbanas no Município de São Paulo, sendo que três delas - Operações Urbanas Consorciadas Água Branca (22\%), Água Espraiada (10\%) e Faria Lima $(10 \%)$ - preveem subvinculação dos recursos captados para viabilização de habitações de interesse social. 55 Arts. 111 e 112 do Plano Diretor Estratégico (Lei Municipal no 16.050, de 31 de julho de 2014).

${ }^{56}$ Ao longo desse trabalho a expressão "arranjo institucional" será constantemente usada. Não será objeto dessa dissertação uma análise propedêutica do conceito. De toda forma, a expressão será empregada, conforme definição dada por Maria Paula Dallari Bucci (2013, cap. 3, sem página - livro eletrônico): "Arranjo institucional é locução que conota o agregado de disposições, medidas e iniciativas em torno da ação governamental, em sua expressão exterior, com um sentido sistemático. É utilizada em substituição à expressão vaga 'outcomes dos processos políticos'. Como a exteriorização de uma política pública é muito diversa e variável, a noção de arranjo, menos comprometida com um aspecto formal determinado, é mais adequada à descrição do fenômeno, dado que qualquer política pública é necessariamente a composição de um conjunto de elementos, normas, órgãos, valores, interesses, orientado à implementação de uma mudança estratégica. $O$ arranjo institucional de uma política compreende seu marco geral de ação, incluindo uma norma instituidora (com o perdão da tautologia), da qual conste o quadro geral de organização da atuação do Poder Público, com a discriminacão das autoridades competentes, as decisões previstas para a concretização da política, além do balizamento geral das condutas dos agentes privados envolvidos, tanto os protagonistas da política quanto os seus destinatários ou pessoas e entes por ela afetados, como empresas e consumidores, por exemplo" (grifos meus). Esse caráter de "mapa de competências" vinculado ao arranjo institucional será bastante destacado ao longo do capítulo 2 deste trabalho.
} 
cidade se o Município não almejar pleitear estes recursos federais e for nessa empreitada bem-sucedido.

Por esses motivos, supõe-se que São Paulo possui um grau relevante de maturidade institucional para rapidamente incorporar e articular uma grande política de provimento habitacional como o MCMV ao arcabouço urbanístico da cidade, caso isso fosse buscado por seus mandatários. Além disso, pelos enormes desafios habitacionais do município, supõe-se que o financiamento garantido pelo programa federal deve ser um importante recurso para viabilizar a política de provimento de habitação de interesse social na capital paulista. A hipótese, portanto, é que, por suas características econômicas, institucionais e regulatórias, São Paulo tem o potencial de apresentar uma implementação do MCMV Faixa 1 com inovações, que serão desvendadas neste trabalho.

Em outras palavras e retomando as ideias anteriormente apresentadas, de que a implementação do MCMV Faixa 1 não é "automática e uniforme" pelos responsáveis legalmente estabelecidos, e de que cada município tem suas particularidades no momento em que a política "chega" à cidade, é interessante saber que tipo de dificuldades, impasses e inovações decorreram desse "casamento" entre uma política federal e as particularidades locais. É igualmente importante entender por meio de que processos jurídicos tais dificuldades e impasses são, em alguns casos, solucionados com ganhos de efetividade ${ }^{57}$ para o MCMV na cidade de São Paulo.

\footnotetext{
57 Ao tratar da importância do direito como uma "tecnologia" voltada ao desenvolvimento, Coutinho, sem utilizar especificamente a expressão "efetividade", acaba abordando o tema de maneira bastante clara: "Por isso, cabe, em grande medida, ao direito das políticas públicas redistributivas evitar que ocorram distorções e falhas de diferentes naturezas, mas sobretudo aquelas resultantes da própria estruturação e operação jurídica dessas políticas. Assim, diante disso, pode-se dizer que uma das principais funções que o direito - e seus operadores - pode cumprir em políticas de desenvolvimento voltadas para a redução da pobreza e da desigualdade é a de minimizar desvios de finalidade, erros de inclusão e exclusão, obliteração do escopo, desperdício de recursos, multiplicação desnecessária de tarefas, existência de lacunas e de disputas de competência, falta de transparência e controle social no desenho, implementação e avaliação dessas políticas, bem como toda sorte de ineficiências (expressão adotada aqui como designação genérica) que façam com que o esforço de desenvolvimento produza externalidades ou custos sociais desnecessários ou gere efeitos concentradores de renda. Ao fazê-lo, o direito, como uma "tecnologia" voltada ao desenvolvimento, assegurará ganhos de equidade, isto é, melhoras qualitativas nos índices de desigualdade e pobreza e, com isso, contribuirá para o desenvolvimento." (COUTINHO, 2013, sem página - livro eletrônico).
} 
Pode-se supor que as próprias dificuldades podem ser fontes de inovação para a política pública, e isso é parte do que quer se demonstrar ao final desta dissertação. Sobre esse tema, há extensa literatura na ciência política que trata da relevância da fase de implementação na conformação das políticas públicas ("bottom up"), tendo em vista que, na realidade, não há um ciclo estanque que separa a formulação e o planejamento da execução das ações governamentais, mas que todas essas fases ocorrem de maneira simultânea e influenciam uma a outra no processo (SABATIER, 1986, p. 30-36; HJERN e HULL, 1982, passim; ELMORE, 1979, passim; LOTTA, 2012, p. 8-19). Nesse sentido, as alterações em decorrência das dificuldades de implementação não são patologias na execução das políticas públicas, mas fazem parte do próprio processo de sua execução.

Conforme se verá no terceiro capítulo deste trabalho, um exemplo marcante da ausência de terrenos economicamente viáveis na cidade de São Paulo foi a necessidade de se adensar verticalmente os empreendimentos do Faixa 1 e, para tal, foi preciso alterar uma regulação do Ministério das Cidades que vedava a existência de elevadores nesses imóveis. A flexibilização mencionada é um caso típico de como a implementação pode trazer inovações decorrentes de entraves comuns da política.

\section{4 Metodologia e organização da dissertação}

Como metodologia, utiliza-se sobretudo o estudo de caso, partindo da premissa de que cada implementação do MCMV Faixa 1 é um caso particular. Nesse sentido e usando as lições de Robert Yin, trata-se de um estudo de caso único, justificado como sendo um caso crítico, em que

o caso único pode representar uma contribuição significativa para a formação do conhecimento e da teoria, confirmando, desafiando ou ampliando a teoria. Esse estudo pode até mesmo ajudar a reenfocar as futuras investigações em todo um campo (YIN, 2015, p. 54-56).

Para a viabilização dos objetivos de pesquisa, foram utilizados os seguintes métodos complementares: 
a) análise de diplomas legais, infralegais, convênios e contratos referentes às modalidades do Faixa 1 desde sua criação no Município de São Paulo: tal método serviu para permitir o mapeamento dos objetivos, das ferramentas e do arranjo institucional do programa instituído pelo governo federal (capítulo 2), e também para avaliar como as modalidades analisadas do MCMV têm sido incorporadas localmente na legislação da cidade de São Paulo (capítulo 3).

Por meio desse método, também foi possível traçar um quadro evolutivo da política pública, na medida em que suas adaptações e alterações estão refletidas nestas normas e contratos, acompanhando tanto as fases do programa determinadas no âmbito federal, quanto as inovações institucionais utilizadas nos novos marcos jurídicos municipais, como o Plano Diretor Estratégico e a Lei de Parcelamento, Uso e Ocupação do Solo;

b) análise bibliográfica interdisciplinar: conforme já indicado, dada a complexidade dessa política pública, diversos acadêmicos, gestores públicos, movimentos sociais e institutos de pesquisa têm se debruçado sobre os impactos do programa MCMV no país. Tendo em vista o instrumental limitado que uma investigação restrita apenas à bibliografia jurídica poderia implicar para a compreensão do programa, este trabalho levou em consideração o maior número e as mais diversas contribuições sobre o tema para realizar uma análise crítica sobre os impactos da política. Nesse compêndio, foram particularmente relevantes para esta dissertação as contribuições de estudos empíricos ou de análise de dados sobre o programa, na maioria das vezes realizados por urbanistas ou cientistas sociais;

\section{c) análise de documentos governamentais contendo dados sobre o} MCMV: voltada à compreensão das dimensões quantitativas da política pública em São Paulo, especialmente no que toca ao volume de unidades habitacionais contratadas e entregues. Os dados quantitativos também servem para oferecer um parâmetro comparativo entre a execução do MCMV Faixa 1 em São Paulo e em outros municípios brasileiros, bem como traçar 
um quadro evolutivo da política nas diferentes gestões que passaram pela cidade;

d) entrevistas semiestruturadas com gestores públicos municipais: foram utilizadas para compreender quais são as dificuldades enfrentadas pelos gestores na implementação da política pública no município, bem como para conferir ao trabalho um componente qualitativo das soluções adotadas e suas motivações ao longo dos oito anos do MCMV Faixa 1 na cidade.

Foram realizadas quatro entrevistas semiestruturadas, sendo: uma com a assessora especial do atual secretário de Habitação do Município de São Paulo (Marcia Terlizzi, ${ }^{58}$ por indicação explícita do secretário Fernando Chucre - gestão João Doria); duas com ex-secretários de Habitação (Ricardo Pereira Leite ${ }^{59}$ - gestão Gilberto Kassab e João Sette Whitaker Ferreira ${ }^{60}$ gestão Fernando Haddad); e uma entrevista com ex-assessor especial da Secretaria de Governo do Município de São Paulo (Celso Santos Carvalho61 - Gestão Fernando Haddad).

A seleção de entrevistados da alta administração da Secretaria de Habitação decorre do fato de que essa é a pasta da Administração Direta ${ }^{62}$ responsável por incorporar o MCMV Faixa 1 na política municipal.

\footnotetext{
58 Apesar de sua indicação ter sido feita pelo atual Secretário de Habitação do Município de São Paulo, Fernando Chucre, Márcia Terlizzi é funcionária de carreira da Prefeitura de São Paulo, tendo atuado em cargos de chefia, assessoramento e direção na SEHAB por mais de uma década.

59 Além de secretário de Habitação entre 2010 e 2012, Leite foi diretor (2005-2006) e presidente da COHAB (2009-2012), bem como secretário adjunto de Habitação (2009-2010).

60 Atuou como secretário entre dezembro de 2015 e dezembro de 2016. Antes dele, também na gestão Fernando Haddad, atuou como secretário de Habitação o engenheiro José Floriano de Azevedo Marques Neto (2013-2015).

${ }^{61}$ Atuou como assessor especial da Secretaria Municipal de Governo entre maio de 2014 e outubro de 2015, com a função de acompanhar o Programa de Metas da gestão Fernando Haddad, especialmente no tocante à sua meta 35 - "Obter terrenos, projetar, licitar, licenciar, garantir a fonte de financiamento e produzir 55 mil Unidades Habitacionais". Para mais informações sobre o Programa de Metas (2013-2016), ver http://www.prefeitura.sp.gov.br/cidade/secretarias/upload/planejamento/arquivos/15308-

004 AF FolhetoProgrmadeMetas2Fase.pdf.

62 Outra protagonista da implementação do MCMV Faixa 1 na cidade é a COHAB-SP, empresa pública vinculada à $S E H A B$, que é responsável principalmente pela operacionalização da política habitacional concebida pela Administração Direta.
} 
Quanto à escolha de se entrevistar secretários e ex-secretários de habitação (cada um de uma das gestões acima mencionadas) ou quem eles indicassem (caso da assessora especial Marcia Terlizzi), essa decisão decorreu do fato de que estas pessoas foram ou ainda são atores políticos relevantes na execução do programa. Possuem uma visão macro das dificuldades de implementação do MCMV Faixa 1, bem como da relevância do programa para o todo da política de habitação do Município de São Paulo, inclusive no tocante à sua relação com o governo federal e outros atores relevantes no arranjo institucional da política pública como empresas, a Caixa Econômica ou movimentos sociais.

No que tange à entrevista com ex-assessor especial da Secretaria de Governo (SEGOV) do município no início do governo Fernando Haddad, esta ocorreu porque se formou um grupo de acompanhamento do Programa de Metas na pasta e uma de suas principais atribuições era acompanhar a intenção de viabilizar 55 mil casas ao longo da gestão Fernando Haddad, sendo que o MCMV era o principal instrumento para atingir esse objetivo. Como essa meta era acompanhada especificamente por Celso Carvalho, ${ }^{63}$ o ex-assessor possuía uma visão ampla das dificuldades e adaptações do programa na cidade ao longo do referido período.

Esta dissertação está organizada em quatro capítulos, contadas a introdução e a conclusão, conforme explicitado a seguir:

O segundo capítulo servirá para apresentar os objetivos, o arranjo institucional e as ferramentas do MCMV Faixa 1. A proposta é evidenciar o que desejava o governo federal com o lançamento do programa e, posteriormente, com

63 A indicação de Celso Carvalho foi feita por outros agentes públicos, que apontaram que este servidor tinha especificamente a função de "destravar" os empreendimentos do MCMV Faixa 1 na Prefeitura. Inicialmente focada no acompanhamento do licenciamento dos empreendimentos, sua atuação acabou sendo mais ampla, incluindo o acompanhamento personalizado de empresas e entidades organizadoras que viabilizavam unidades habitacionais na cidade. Em suas próprias palavras: "Nesse sentido, a minha relação era de monitoramento do programa, do andamento dessa meta, acompanhamento do processo de implementação dos empreendimentos pela secretaria de Governo. Então, desde desapropriação, aprovação de projetos, licenciamento, contratação com a Caixa". 
as alterações que se seguiram entre 2009 e 2017, bem como ressaltar quais instrumentos a União lançou mão para tornar isso possível. Ao tratar do arranjo institucional, ou seja, o "mapa de competências" de quem faz o quê para viabilizar o programa, se dará especial atenção ao papel da União e dos Municípios, já que, como dito, esse trabalho parte de uma base teórica de estudos sobre a articulação interfederativa para tratar do MCMV.

No terceiro capítulo, em que está o cerne do trabalho, realiza-se a análise de um estudo de caso de implementação do MCMV Faixa 1 no Município de São Paulo. Partindo de uma ótica jurídica e baseando-se tanto na análise legislativa, contratual e de editais de chamamento dos empreendimentos, como na percepção de gestores municipais, serão apresentados os desafios de viabilizar a implementação de um programa one size fits all desenhado em Brasília e como a municipalidade criou instrumentos inovadores e adaptativos para lidar com as dificuldades da política na cidade.

Por fim, o quarto e último capítulo será destinado à conclusão, em que serão destacados, de maneira crítica, quais são os aprendizados extraídos do estudo de caso, indicando medidas tendentes a aprimorar o programa. 


\section{Conclusão}

O MCMV é um mundo. Lançado inicialmente como uma política anticíclica de combate à crise econômica de 2008, o programa rapidamente se transformou em uma marca facilmente reconhecível pelos brasileiros como uma grande política pública de provimento habitacional.

Apesar da drástica redução nos últimos dois anos, a escala de mais de 4 milhões de unidades habitacionais contratadas em menos de uma década fez o programa se tornar pauta relevante de campanhas eleitorais para a Presidência da República, impactou indicadores econômicos como emprego e renda e mobilizou um público-alvo ávido por realizar o "sonho da casa própria", que era tão diverso a ponto de envolver o que Paul Singer (1981) chamou de subproletariado ${ }^{205}$ dos rincões rurais do país até os representantes da nova classe média ${ }^{206}$ das regiões metropolitanas brasileiras.

Já os acadêmicos, especialmente os urbanistas, indicavam, desde o lançamento do MCMV, a importância da ampliação do financiamento para HIS, mas não escondiam as preocupações de que o programa repetisse erros cometidos no passado, especialmente no período do $\mathrm{BNH}$, como a segregação dos mais pobres para áreas periféricas, sem infraestrutura urbana e provimento de bens e serviços.

\footnotetext{
205 No Brasil, a expressão subproletariado foi popularizada por Paul Singer em seu livro de 1981, Dominação e desigualdade: Estrutura de Classe e repartição da renda no Brasil. A expressão voltou a ganhar notoriedade a partir da década de $2010 \mathrm{com}$ as análises de seu filho, André Singer, sobre o Lulismo. A definição simplificada pode se dar pela expressão "sobrepopulação trabalhadora superempobrecida permanente" (Singer, 2012, p.19), que, desde a segunda eleição que consagrou Luiz Inácio Lula da Silva, passaria a ser o "núcleo duro" do apoio eleitoral ao petista. Adicionalmente à expressão indicada, aponta-se que o subproletariado é, em geral, constituído de trabalhadoras e trabalhadores informais, com baixo nível de proteção social e extremamente vulnerável às flutuações macroeconômicas do país. Embora não seja uma regra absoluta, no caso do MCMV, o público-alvo da Faixa 1 (indivíduos cuja renda familiar é de zero a três salários mínimos), objeto central desta dissertação, está englobado no conceito de subproletariado.

${ }^{206}$ A expressão "nova classe média" parte da definição dada pelo economista Marcelo Neri em seus estudos sobre a população brasileira de renda média, também conhecida como Classe C: "Conceito: Nova classe média foi o apelido que demos à Classe $C$ há anos. (...) Nova classe média dá o sentido positivo e prospectivo daquele que realizou - e continua a realizar - o sonho de subir na vida. Aonde você vai chegar é mais importante do que de onde você veio ou onde você está. Nova classe média não é definida pelo ter, mas pela dialética entre ser e estar olhando para a posse de ativos e para decisões de escolha entre o hoje e o amanhã. Mais do que assíduos frequentadores de templos de consumo, o que caracteriza a nova classe média é o lado produtor. A nova classe média busca construir seu futuro em bases sólidas que sustentam o novo padrão adquirido." (NERI, 2011, p. 1819.)
} 
A avaliação da implementação do MCMV ao longo da última década confirmou parte das inquietações da academia (AMORE et al., 2015; CARDOSO et al., 2013; KRAUSE, BALBIM e NETO, 2013; ROLNIK et al., 2015). De fato, em grande parte do país, os empreendimentos do MCMV Faixa 1 destinados à base da pirâmide foram majoritariamente construídos em áreas afastadas, com carências de infraestrutura e baixo acesso a serviços públicos. Em outras palavras, a política garantiu teto, mas ainda está longe de assegurar moradia adequada ${ }^{207}$ para os brasileiros menos favorecidos.

Por outro lado, talvez o mais positivo, o MCMV Faixa 1 teve uma enorme adesão. Diferentemente do $\mathrm{BNH}$, por exemplo, o programa de provimento habitacional estatal de larga escala não privilegiou a classe média em detrimento dos mais pobres. Representando aproximadamente metade dos imóveis entregues da política, mais de 1 milhão de casas foram garantidas àqueles com renda familiar de até $\mathrm{R} \$ 1.800,00$ por mês, e mais de 750 mil unidades habitacionais já estão contratadas.

Diante desse contexto de sucesso na produção de casas e relativo fracasso na garantia da qualidade é que me interessei por estudar mais detidamente a implementação do MCMV Faixa 1, buscando compreender se e como o direito exercia alguma influência nessa conjuntura. As pesquisas empreendidas me levaram a concluir que não havia como fazer um estudo geral sobre o MCMV no país, mas

207 O Pacto Internacional sobre Direitos Econômicos, Sociais e Culturais define, em seu Artigo 11: "Os Estados Partes do presente Pacto reconhecem o direito de toda pessoa a um nível de vida adequando para si próprio e sua família, inclusive à alimentação, vestimenta e moradia adequadas, assim como a uma melhoria continua de suas condições de vida. Os Estados Partes tomarão medidas apropriadas para assegurar a consecução desse direito, reconhecendo, nesse sentido, a importância essencial da cooperação internacional fundada no livre consentimento." No Comentário Geral oo 4 do Comitê de Direitos Econômicos, Sociais e Culturais, entre outros pontos, destaca-se o seguinte item, que compõe o que é uma moradia adequada: "b. Disponibilidade de serviços, materiais, facilidades e infraestrutura. Uma casa adequada deve conter certas facilidades essenciais para saúde, segurança, conforto e nutrição. Todos os beneficiários do direito à habitação adequada deveriam ter acesso sustentável a recursos naturais e comuns, água apropriada para beber, energia para cozinhar, aquecimento e iluminação, facilidades sanitárias, meios de armazenagem de comida, depósito dos resíduos e de lixo, drenagem do ambiente e serviços de emergência. (...) f. Localização. A habitação adequada deve estar em uma localização que permita acesso a opções de trabalho, serviços de saúde, escolas, creches e outras facilidades sociais. Isso é válido para grandes cidades, como também para as áreas rurais, em que os custos para chegar ao local de trabalho podem gerar gastos excessivos sobre o orçamento dos lares pobres. Similarmente, habitações não deveriam ser construídas em locais poluídos nem nas proximidades de fontes de poluição que ameacem o direito à saúde dos habitantes." 
que eu precisaria me ater a uma localidade, já que as particularidades regulatórias, fundiárias, econômicas e sociais das cidades impactam na forma como o programa é implementado.

A escolha de aprofundar o estudo em São Paulo decorreu dos enormes desafios habitacionais da cidade, que deveriam conduzir à necessidade de aderir a um programa como o MCMV; da maturidade institucional da maior Prefeitura do país, com larga experiência no uso de instrumentos urbanísticos previstos no Estatuto da Cidade e um corpo técnico grande e experiente na produção de HIS; e de uma inquietação quanto à relevância do alinhamento político entre os governos municipal e federal para a implementação do MCMV Faixa 1, já que São Paulo teve momentos de alternância entre governos aliados e opositores no período.

As conclusões da pesquisa confirmaram a maioria das hipóteses iniciais. De fato, é preciso vontade política dos gestores municipais para implementar o MCMV Faixa 1, e a forma como o município recebe o programa federal tem impacto em questões como inserção urbanística dos empreendimentos, qual modalidade é privilegiada (se "Entidades" ou "Empresas") e até no tempo de execução da política.

Além disso, ficou constatado que arranjos jurídicos podem dificultar, facilitar e até alterar elementos do programa. Esse caráter funcional do direito para viabilização da política pública foi observado na necessidade de adaptações burocráticas das secretarias, na complementação financeira aos subsídios federais por parte do município e até mesmo nas alterações procedimentais no rito da desapropriação de terrenos para executar o programa, todas essas mudanças que requereram alterações normativas municipais.

Já o arranjo institucional, por exemplo, que legou ao Ministério das Cidades grande parte do papel regulamentador da tipologia dos imóveis do programa inviabilizou por mais de cinco anos a verticalização dos empreendimentos em São Paulo, o que é um enorme entrave para uma cidade que possui o segundo metro quadrado mais caro do país. Por sua vez, a garantia de que essa verticalização não geraria impacto sobre a segurança dos beneficiários, fator que era a base da proibição do uso de elevadores pelo órgão federal, foi revertida com um outro instrumento jurídico - um acordo de cooperação entre CEF, SEHAB e COHAB, em que a Prefeitura se comprometia a arcar com os custos de manutenção do ascensor. 
Ainda, o trabalho reforçou a defesa da literatura de que os instrumentos urbanísticos contidos no Plano Diretor têm o potencial de facilitar a execução de políticas de produção habitacional de interesse social como o MCMV Faixa 1. A vinculação de $30 \%$ de recursos do FUNDURB para desapropriação de imóveis destinados para HIS no PDE de 2014 foi uma importante fonte de recursos para viabilizar a formação de um banco de terras municipal, enquanto as ZEIS parecem ter delimitado localidades centrais e, portanto, dotadas de maior infraestrutura, em que empreendimentos do MCMV Faixa 1 poderão ser implementados futuramente quando se voltar a disponibilizar mais recursos orçamentários para o programa no âmbito federal.

Além disso, como uma reflexão sobre a possibilidade de aprimoramento do MCMV Faixa 1 colhida nas entrevistas realizadas para este trabalho, seria interessante a realização de estudos sobre a viabilidade de se separar o valor da terra dos valores construtivos para a formação do montante a ser subsidiado no provimento de HIS.

Isso se dá na medida em que o valor dos terrenos aparece em São Paulo (e na maior parte das regiões metropolitanas brasileiras) como um dos principais entraves para "fechar a conta" dos empreendimentos. Se a CEF, assessorada pelas prefeituras para indicar as áreas dotadas de infraestrutura urbana nessas localidades, ficasse responsável por viabilizar a compra dos terrenos e se especializasse nesse tipo de aquisição, com dados comparativos que indicassem por que valores é viável desapropriar determinados tipos de glebas, poderia haver uma redução dos gastos do Estado para esse fim. Além disso, na medida em que haveria um comprador com um volume relevante de recursos e informações dos custos razoáveis para serem alocados nas áreas a serem implementadas empreendimentos do MCMV Faixa 1, poderia ocorrer um ganho de eficiência, melhorando a inserção urbanística dos imóveis e, possivelmente, até reduzindo os gastos do programa.

Da mesma forma, seria extremamente interessante que se aprofundassem estudos econômicos sobre o papel das ZEIS na redução do valor da terra relacionada à implementação do MCMV Faixa 1 na cidade de São Paulo, já que não 
parece haver um parâmetro claro de que valores dispendidos são vantajosos nas desapropriações para a formação do banco de terras municipal, por exemplo.

Finalmente, espera-se que, com este trabalho, tenha sido possível colocar mais uma peça no grande quebra-cabeça que pesquisadoras e pesquisadores em todo o Brasil (e até fora dele) vem montando na tentativa de compreender o Minha Casa, Minha Vida. Acredito que esse grande esforço que a academia faz de entender e criticar uma das maiores políticas públicas de provimento habitacional da história do país é imperativa para o aprimoramento institucional e, portanto, uma importante colaboração na busca por garantia de moradia digna a milhões de brasileiros e brasileiras. 


\section{Referências bibliográficas}

ABRUCIO, Fernando Luiz. A dinâmica federativa da educação brasileira: diagnóstico e propostas de aperfeiçoamento. In: Educação e federalismo no Brasil: combater as desigualdades, garantir a diversidade. Brasília: UNESCO, 2010, p. 39-70.

; FRANCESE, Cibele. Federalismo e políticas públicas: o impacto das relações intergovernamentais no Brasil. Tópicos de economia paulista para gestores públicos, v. 1, p. 13-31, 2007.

ACOSTA, Cláudia. O programa federal brasileiro "Minha Casa, Minha Vida" é um regulador-sombra das normas urbanísticas municipais?. 2015. Dissertação (Mestrado) - Escola de Direito de São Paulo da Fundação Getúlio Vargas, 2015.

AFIUNE, Giulia; MOTA, Jessica; VIANA, Natalia. O que descobrimos. Agência pública, 20 jul. 2016. Disponível em: https://apublica.org/100/?page id=20.

AGÊNCIA CAIXA DE NOTÍCIAS. Minha Casa Minha Vida impulsiona criação de empregos.

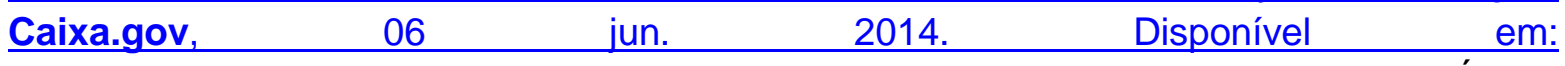

http://www20.caixa.gov.br/Paginas/Noticias/Noticia/Default.aspx?newsID=917. Último acesso em 13 de outubro de 2017.

ALFONSIN, Betânia de Moraes. Políticas de regularização fundiária: justificação, impactos e sustentabilidade. In: FERNANDES, Edésio (org.): Direito Urbanístico e Política Urbana no Brasil. Belo Horizonte: Del Rey, 2001.

AMORE, Caio Santo; SCHIMBO, Lúcia Zanin; RUFINO, Maria Beatriz Cruz (orgs.). Minha casa... e a cidade? Avaliação do programa minha casa minha vida em seis estados brasileiros. Rio de Janeiro: Letra Capital, 2015.

ARRETCHE, Marta. Federalismo e relações intergovernamentais no Brasil. DADOS - Revista de Ciências Sociais, Rio de Janeiro, v. 45, n. 3, p. 431-458, 2002.

. Federalismo e políticas sociais no Brasil: problemas de coordenação e autonomia. São Paulo em perspectiva, v. 18, n. 2, p. 17-26, 2004.

et al (orgs.). Capacidades administrativas dos municípios brasileiros para a política habitacional. São Paulo: Centro de Estudos da Metrópole/ Ministério das Cidades, 2012. 
ARRIGOITIA, Melissa Fernández. Unsettling Resettlements: Community, Belonging and Livelihood in Rio de Janeiro's Minha Casa Minha Vida. In: Geographies of Forced Eviction. Basingstoke, UK: Palgrave Macmillan, 2017, p. 71-96.

BANCO CENTRAL DO BRASIL. Relatório Anual 2008. Boletim do Banco Central do Brasil, v. 44. p. 1-253, 2009.

BERCOVICI, Gilberto. Constituição econômica e desenvolvimento: uma leitura a partir da Constituição de 1988. São Paulo: Malheiros Editores, 2005.

$O$ ainda indispensável direito econômico. In: ; BENEVIDES, Maria

V. de M; MELO, Claudineu de (orgs.). Direitos humanos, democracia e república: homenagem a Fábio Konder Comparato. São Paulo: Quartier Latin, 2009.

BONATELLI, Circe. Minha Casa puxa expansão do mercado imobiliário. Estado de S.Paulo, 21 jul. $2017 . \quad$ Disponível em: http://economia.estadao.com.br/noticias/geral,minha-casa-puxa-expansao-domercado-imobiliario,70001898630. Último acesso em 29 de novembro de 2017.

BONDUKI, Nabil. Política habitacional e inclusão social no Brasil: revisão histórica e novas perspectivas no governo Lula, 2008. Revista Eletrônica de Arquitetura e Urbanismo. Disponível em: http://www.usjt.br/arq.urb/numero_01/artigo_05_180908.pdf. Último acesso em 11 de junho de 2016.

O boom imobiliário vai chegar à habitação de interesse social?. Agência Estado, 15 de janeiro de 2008.

. Do Projeto Moradia ao Programa Minha Casa Minha Vida. TD. Teoria e Debate, v. 82, p. 1, 2009.

Origens da habitação social no Brasil: Arquitetura moderna, Lei do Inquilinato e Difusão da Casa Própria, 5a edição. São Paulo: Estação Liberdade, 2011.

. Os pioneiros da habitação social: Cem anos de política pública no Brasil. São Paulo: Editora Unesp, 2012.

Planos Locais de Habitação: das origens aos dilemas atuais nas regiões metropolitanas. In: Rosana Denaldi (org.): Planejamento habitacional: notas sobre a precariedade e terra nos Planos Locais de Habitação. São Paulo: Annablume, 2013. 
BOULOS, Guilherme. De que lado você está?: reflexões sobre a conjuntura política e urbana no Brasil. São Paulo: Boitempo Editorial, 2015.

BRAGA, Juliana. Haddad propõe elevador em prédios do Minha Casa, Minha Vida em SP. G1, 10 abr. 2014. Disponível em: http://g1.globo.com/saopaulo/noticia/2014/04/haddad-propoe-elevador-em-predios-do-minha-casa-minhavida-em-sp.html. Último acesso dia 18 de dezembro de 2017.

BREGA, J. F. F. O Fundo de Arrendamento Residencial como veículo do Programa Minha Casa, Minha Vida: inovações e questões subjacentes. R. Fórum Dir. fin. e Econômico - RFDFE, Belo Horizonte, ano 5, n. 8, p. 79-97, set./fev. 2016.

BUCCI, Maria Paula Dallari. Cooperativas de habitação no direito brasileiro. Editora Saraiva, 2000.

. Direito Administrativo e Políticas Públicas. São Paulo: Saraiva, 2002.

. O conceito de política pública em direito. Políticas públicas: reflexões sobre o conceito jurídico. São Paulo: Saraiva, p. 1-49, 2006.

Notas para uma metodologia jurídica de análise de políticas públicas. Políticas públicas: possibilidades e limites. Belo Horizonte: Fórum, p. 225-260, 2008.

. Fundamentos para uma Teoria Jurídica das Políticas Públicas. São Paulo: Saraiva, 2013.

. Quadro de referência de uma Política Pública: Primeiras linhas de uma visão jurídico-institucional. SMANIO, GianpaoloPoggio; BERTOLIN, Patrícia Tuma Mantins Bertolin; BRASIL. O Direito na Fronteira das Políticas Públicas. São Paulo: Páginas \& Letras Editora e Gráfica, 2015.

.; COUTINHO, Diogo Rosenthal. Arranjos jurídico-institucionais da política de inovação tecnológica: uma análise baseada na abordagem de direito e políticas públicas. In: Diogo R. Coutinho; Maria Carolina Foss; Pedro Salomon B. Mouallem. (Org.). Inovação no Brasil: avanços e desafios jurídicos e institucionais. 1ed.São Paulo: Editora Edgard Blücher Ltda., 2017, v. 1, p. 313-339.

CAMARGO, Camila Moreno de. Minha Casa Minha Vida Entidades: entre os direitos, as urgências e os negócios. 2016. Tese (Doutorado) - Universidade de São Paulo, 2016. 
. MCMV Entidades: outras interações reguladas pelo mercado. Anais do XVII ENANPUR. São Paulo, 2017.

CANE, Peter; KRITZER, Herbert (orgs.). The Oxford handbook of empirical legal research. Oxford: Oxford University Press, 2012.

CARDOSO, Adauto Lúcio; ARAGÃO, Themis Amorim (orgs.). O Programa Minha Casa Minha Vida e seus efeitos territoriais. Rio de Janeiro: Letra Capital, 2013.

; MELLO, Irene de Queiroz; JAENISCH, Samuel Thomas. A implementação do Programa Minha Casa Minha Vida na Região Metropolitana do Rio de Janeiro: agentes, processos e contradições. In: AMORE, Caio; SHIMBO, Lúcia Zanin; RUFINO, Maria Beatriz Cruz (orgs.). Minha casa... e a cidade? avaliação do programa minha casa minha vida em seis estados brasileiros, $1^{a}$. ed. Rio de Janeiro: Letra Capital, 2015.

CAVALCANTE, Pedro; CUNHA, Bruno Queiroz. É preciso inovar no governo, mas por quê? In: Inovação no Setor Público: teoria, tendências e casos no Brasil. Brasília: IPEA, 2017, p. 15-32.

et al. Inovação no Setor Público: teoria, tendências e casos no Brasil. Brasília: IPEA, 2017.

COELHO NISIDA, Vitor et al. A inserção urbana dos empreendimentos do programa Minha Casa Minha Vida na escala local: uma análise do entorno de sete conjuntos habitacionais. Revista Brasileira de Estudos Urbanos e Regionais, v. 17, n. 2, 2015.

COHAB. Relatório de Gestão 2013-2016. São Paulo, 2016.

COMPARATO, Fábio Konder. O indispensável direito econômico. In: Ensaios e pareceres de direito empresarial. Rio de Janeiro: Forense, 1978.

COUTINHO, Diogo Rosenthal. Linking Promises to Policies: Law and Development in an Unequal Brazil. The Law and Development Review, 2010a.

O direito nas políticas públicas de habitação: usos de instrumentos urbanísticos no Município de Santo André, Brasil. Final paper apresentado ao Lincoln Institute of Land Policy, 2010b.

Direito, Desenvolvimento e Desigualdade. São Paulo: Saraiva, 2013. 
. Direito Econômico e Desenvolvimento Democrático: uma abordagem institucional. Tese (Concurso de provas e títulos para provimento de cargo de Professor Titular) - Departamento de Direito Econômico, Financeiro e Tributário, área de Direito Econômico e Economia Política, na Faculdade de Direito da Universidade de São Paulo (Edital FD 01/2014), 2014a.

. Entre eficiência e legitimidade: O Bolsa Família no desafio de consolidação do SUAS. In: GOMIDE, AA; PIRES, Roberto (orgs.). Capacidades Estatais e Democracia: a abordagem dos arranjos institucionais de políticas públicas. Brasília: Ipea, 2014b.

; ROCHA, Jean-Paul Veiga da; SCHAPIRO, Mario G. Direito Econômico atual. Rio de Janeiro: Forense, 2015.

D'AMORIM, Sheila; PERES, Leandra; IGLESIAS, Simone. Plano de Lula prevê R\$ 34 bi para habitação. Folha de S. Paulo, 26 mar. 2009. Disponível em: http://www1.folha.uol.com.br/fsp/dinheiro/fi2603200902.htm. Último acesso em 11 de novembro de 2017.

DAGLIO, M.; GERSON, D.; KITCHEN, H., Building Organisational Capacity for Public Sector Innovation. Background Paper prepared for the OECD Conference Innovating the Public Sector: from Ideas to Impact, Paris, 12-13 nov. 2014.

DENALDI, Rosana et al. Planos Locais de Habitação de Interesse Social na Região Metropolitana de São Paulo. In: (org.). Planejamento habitacional: notas sobre a precariedade e terra nos Planos Locais de Habitação. São Paulo: Annablume, 2013.

DENALDI, R. Política habitacional e urbana: avanços e impasses. São Paulo, 2012.

. Plano Diretor, Zonas Especiais de Interesse Social e a articulação ao Plano Local de Habitação. In: Denaldi (org.). Planejamento habitacional: notas sobre a precariedade e terra nos Planos Locais de Habitação. São Paulo: Annablume, 2013.

; JESUS, P. M.. Experiências de regulação urbana e suas possibilidades: análise a partir do Programa Minha Casa Minha Vida na Região do Grande ABC (São Paulo). EURE Revista Latinoamericana de Estudios Urbano Regionales, 2017. 
DE VRIES, H.; BEKKERS, V.; TUMMERS, L. Innovation in the public sector: a systematic review and future research agenda. Public Administration, v. 94, n. 1, p. 146-166, 2016.

DIAS, Edney Cielici. Do Plano Real ao Programa Minha Casa, Minha Vida. Negócios, votos e as reformas de habitação. Dissertação (Mestrado) - FFLCH-USP, 2012.

ELMORE, Richard F. Backward mapping: Implementation research and policy decisions. Political science quarterly, v. 94, n. 4, p. 601-616, 1979.

ESTADO DE MINAS. Governo cumpre só $27 \%$ da meta do Minha Casa Minha Vida após ajustar Faixa 1. Estado de Minas, 11 ago 2017. Disponível em: https://www.em.com.br/app/noticia/economia/2017/08/11/internas economia,89127 1/governo-cumpre-so-27-da-meta-do-minha-casa-minha-vida-apos-ajustar-fa.shtml. Último acesso em 26 de dezembro de 2017.

EXAME. Preço de imóvel residencial sobe 0,7\% em um ano, diz FipeZap. Exame, 4 maio 2017. Disponível em: http://exame.abril.com.br/seu-dinheiro/preco-de-imovelresidencial-sobe-07-em-um-ano-diz-fipezap/. Último acesso em 07 de maio de 2017.

FARAH, Marta Ferreira Santos. Parcerias, novos arranjos institucionais e políticas públicas no nível local de governo. Revista de administração pública, v. 35, n. 1, p. 119-144, 2001.

FERREIRA, João Sette Whitaker. Produzir casas ou construir cidades?. Desafios para um novo Brasil urbano, v. 1. São Paulo: Lahab/ Fupam 2012.

FERREIRA_. Minha Casa, Minha Vida: Notas sobre a responsabilidade coletiva de um desastre urbano. Revista Contraste, v. 1, p. 110-119, 2014.

FIX, Mariana e ARANTES, Pedro Fiori. Minha Casa Minha vida: uma análise muito interessante. Disponível em: http://www.correiocidadania.com.br/content/view/3560/9/. Acesso em 15 de outubro de 2014.

FONSECA, Maria de Lourdes; FERNADES, Camila Nestari. Terra para Habitação de Interesse Social na Região Metropolitana de São Paulo. In: DENALDI, Rosana (org.). Planejamento habitacional: notas sobre a precariedade e terra nos Planos Locais de Habitação. São Paulo: Annablume, 2013. 
FUNDAÇÃO JOÃO PINHEIRO. Centro de Estatística e Informações. Déficit habitacional no Brasil 2013-2014. Belo Horizonte, 2016.

FURTADO, Fernanda. Recuperação de mais-valias fundiárias urbanas: reunindo os conceitos envolvidos. In: SANTORO, Paula (org.). Gestão social da valorização da terra. São Paulo: Instituto Pólis, 2004.

GIRALDI, Renata. Dilma rebate críticas ao pacote habitacional e diz que nem amarrada confirma candidatura. Folha online, 26 mar. 2009. Disponível em: http://www1.folha.uol.com.br/poder/2009/03/540823-dilma-rebate-criticas-aopacote-habitacional-e-diz-que-nem-amarrada-confirma-candidatura.shtml. último acesso em 27 de dezembro de 2017.

GOVERNO DO BRASIL. Com nova fase, Minha Casa Minha Vida vai alcançar 4,6 milhões de casas construídas. Brasil.gov, 30 mar. 2016. Disponível em: http://www.brasil.gov.br/infraestrutura/2016/03/minha-casa-minha-vida-chega-a-3afase-com-2-milhoes-de-novas-moradias-ate-2018. Último acesso em 10 de agosto de 2017.

GRAU, Eros Roberto. Planejamento econômico e regra jurídica. São Paulo: Revista dos Tribunais, 1978.

A ordem econômica na Constituição de 1988 (interpretação e crítica), $12^{a}$ ed. São Paulo: Malheiros, 2007.

. Ensaio e discurso sobre a interpretação/aplicação do direito. São Paulo: Malheiros, 2009.

G1. Brasileiros fazem fila para casa própria. Bom dia Brasil, 17 abr 2009. Disponível em: $\quad$ http://g1.globo.com/bomdiabrasil/0,,MUL1088595-16020,00BRASILEIROS+FAZEM+FILA+PARA+CASA+PROPRIA.html. Último acesso 27 de dezembro de 2017.

"Todo bom programa foi acusado de eleitoreiro", afirma Dilma. G1, 25 mar. 2009. Disponível em: http://g1.globo.com/Noticias/Politica/0,,MUL1058349-5601,00TODO+BOM+PROGRAMA+FOI+ACUSADO+DE+ELEITOREIRO+AFIRMA+DILMA.html. Último acesso em 27 de dezembro de 2017.

HARVEY, David. From managerialism to entrepreneurialism: The transformation in urban governance in late capitalismo. Geografiska Annaler, v. 71, n. 1, 1989.

A produção capitalista do espaço. São Paulo: Annablume, 2005. 
1973.

Social justice and the city, vol. 1. Georgia: University of Georgia Press,

HJERN, Benny; HULL, Chris. Implementation research as empirical constitutionalism. European journal of political research, v. 10, n. 2, p. 105-115, 1982.

INSTITUTO BRASILEIRO DE GEOGRAFIA E ESTATÍSTICA. Censo Demográfico. Família e Domicílio. 2010.

Indicadores sociais: passado, presente e futuro. Gerência de Biblioteca e Acervos Especiais [organizado por André Simões e Antônio Carlos Alkmim]. Rio de Janeiro, 2017.

INSTITUTO DE PESQUISA ECONÔMICA APLICADA. Não tinha teto, não tinha nada. Porque os Instrumentos de Regularização Fundiária (ainda) não efetivaram o Direito à Moradia no Brasil. -rasília: Ministério da Justiça, Secretaria de Assuntos Legislativos (SAL): IPEA, 2016.

O programa Minha Casa Minha Vida em municípios de até $\mathbf{5 0}$ mil habitantes: Quadro institucional e prognósticos da provisão habitacional de interesse social. Comunicado IPEA oㅜ 146. Brasília/ Rio de Janeiro, maio de 2012.

Parcelamento, edificação ou utilização compulsórios e IPTU progressivo no tempo: regulação e aplicação. Brasília: Ministério da Justiça, Secretaria de Assuntos Legislativos (SAL): 321p. : il. color. -- (Série pensando o Direito; 56). 2015.

2016.

Relatório brasileiro para o Habitat III. Brasília: CONCIDADES, IPEA.

KLINTOWITZ, Danielle. Por que o Programa Minha Casa Minha Vida só poderia acontecer em um governo petista?. Cadernos Metrópole, v. 18, n. 35, p. 165-190, 2016.

Entre a reforma urbana e a reforma imobiliária: a coordenação de interesses na política habitacional brasileira nos anos 2000. 2015. Tese (Doutorado) - Fundação Getúlio Vargas, 2015.

KRAUSE, Cleandro; BALBIM, Renato; NETO, Vicente Correia Lima. Minha Casa Minha Vida, Nosso Crescimento: Onde Fica a Política Habitacional. Texto para 
Discussão 1853: Instituto de Pesquisa Econômica Aplicada. Brasília/ Rio de Janeiro, Agosto de 2013.

KRAUSE, Cleandro; FURTADO, Bernardo Alves; NETO, Vicente Correia Lima. Nota Técnica: Estimativas do déficit habitacional brasileiro (2007-2011) por municípios (2010). Instituto de Pesquisa Econômica Aplicada. Brasília/ Rio de Janeiro. Maio de 2013.

LAGO, Luciana Correia do. Autogestão de moradia na superação da periferia urbana: conflitos e avanços. Revista Eletrônica de estudos urbanos e regionais, v. 5, ano 2, jun. 2011.

LAGO, Luciana Correia do (org.). Autogestão habitacional no Brasil: utopias e contradições. Rio de Janeiro: Letra Capital, 2012.

LEFÉBVRE, Henri. O direito à cidade, v. 5. São Paulo: Centauro, 1969.

LIMA, Mauricio. Banco do Brasil passa a financiar imóveis para o Programa Minha Casa, Minha Vida no Distrito Federal. PiniWeb, 31 maio 2011. Disponível em: http://piniweb.pini.com.br/construcao/habitacao/banco-do-brasil-passa-a-financiarimoveis-para-o-programa-219143-1.aspx. Último acesso 12 de julho de 2016.

LIMA NETO, V. C.; KRAUSE, C.; FURTADO, B. A. O déficit habitacional intrametropolitano e a localização de empreendimentos do programa Minha casa, minha vida: mensurando possibilidades de atendimento. In: RESENDE, G. M. (org.). Avaliação de políticas públicas no Brasil: uma análise de seus impactos regionais, v. 2, p. 79-119. Rio de Janeiro: Ipea, 2015.

LOPES, João Marcos de Almeida; SHIMBO, Lucia Zanin. Projeto e produção da habitação na região central do estado de São Paulo: condições e contradições do PMCMV. In: AMORE, Caio; SHIMBO, Lúcia Zanin; RUFINO, Maria Beatriz Cruz (orgs.). Minha Casa... e a Cidade? Avaliação do Programa Minha Casa Minha Vida em seis Estados brasileiros,1 1․ ed. Rio de Janeiro: Letra Capital, 2015.

LOUREIRO, Maria Rita; MACÁRIO, Vinicius; GUERRA, Pedro. Democracia, arenas decisórias e políticas públicas: o Programa Minha Casa Minha Vida. In: GOMIDE, AA; PIRES, Roberto (orgs.). Capacidades estatais e democracia: a abordagem dos arranjos institucionais para análise de políticas públicas. Brasília: Ipea, 2014b.

LOTTA, Gabriela. O papel das burocracias do nível da rua na implementação de políticas públicas: entre o controle e a discricionariedade. In: FARIA, C. A (org.). 
Implementação de Políticas Públicas: Teoria e Prática. Belo Horizonte: Editora PUCMINAS, 2012.

; GONÇALVES, Renata; BITELMAN, Marina. A Coordenação Federativa de Políticas Públicas: uma análise das políticas brasileiras nas últimas décadas. Cadernos Gestão Pública e Cidadania, v. 19, n. 64, 2014.

MAIA, William. Infográfico - Minha Casa Minha Vida - balanço 30.03. Brasil.gov, 30 mar. 2016. Disponível em: http://www.brasil.gov.br/infraestrutura/2016/03/minhacasa-minha-vida-realiza-sonho-da-moradia-propria-para-10-milhoes-debrasileiros/infogrfico29.03MCMVBalano.png/view. Último acesso em 13 de outubro de 2017.

MALERONKA, Camila. Projeto e gestão na metrópole contemporânea: um estudo sobre as potencialidades do instrumento 'operação urbana consorciada' à luz da experiência paulistana (2010). Tese (Doutorado) - Universidade de São Paulo, 2010.

- Intervenção urbana e financiamento: a experiência de São Paulo na recuperação de mais-valias fundiárias. Revista Iberoamericana de Urbanismo, $\mathrm{n}$. 12, p. 75-91, 2015.

MARICATO, Ermínia. Metrópole na periferia do capitalismo: ilegalidade, desigualdade e violência. São Paulo: Hucitec, 1996.

. O nó da terra. Revista Brasileira de Direito Ambiental, v. 15, p. 191-196, 2008.

Para entender a crise urbana. São Paulo: Expressão Popular, 2015.

; FERREIRA, João Sette Whitaker. Operação urbana consorciada: diversificação urbanística participativa ou aprofundamento da desigualdade. In: OSÓRIO, Letícia Marques. Estatuto da Cidade e Reforma Urbana: novas perspectivas para as cidades brasileiras. Porto Alegre: Sergio Fabris Editora, 2002.

MARQUES, Eduardo; RODRIGUES, Leandro. O Programa Minha Casa Minha Vida na Metrópole Paulistana: atendimento habitacional e padrões de segregação. Revista Brasileira de Estudos Urbanos e Regionais, v. 15, n. 2, nov. 2013.

MASSONETTO, Luís Fernando. Operações Urbanas Consorciadas: a Nova Regulação Urbana em Questão". Revista Procuradoria-Geral do Município de Porto Alegre, v. 17, p. 101-118, 2003. 
Pontos cegos da regulação urbanística: notas sobre uma articulação programática entre o direito econômico e o direito urbanístico. In: Revista Fórum de Direito Financeiro e Econômico - RFDFE. Belo Horizonte. Ano 4, n. 6 set./ fev. 2015.

MÁXIMO, Luciano. Déficit habitacional aumenta com a recessão. Valor Econômico, 10 mar. 2017. Disponível em: http://www.valor.com.br/brasil/4882412/deficithabitacional-aumenta-com-recessao. Último acesso em 29 de novembro de 2017.

MERTZ, Elizabeth. Introduction: new legal realism: law and social science in the new millennium. The New Legal Realism, v. 1, p. 1-26, 2016.

MILANO, Joana Zattoni. Um lugar para chamar de seu? O Programa Minha Casa, Minha Vida e a ideologia da casa própria. 2013. Dissertação (Mestrado) Programa de Pós-Graduação em Planejamento Urbano e Regional da UFRGS, Faculdade de Arquitetura. Porto Alegre, 2013.

MIOTO, Beatriz Tamaso. As políticas habitacionais do subdesenvolvimento: os casos do Brasil, Colombia, México e Venezuela (1980/2013). 2015. Tese (Doutorado) - Programa de Pós-Graduação em Desenvolvimento Econômico, área de concentração: Desenvolvimento Econômico, Espaço e Meio Ambiente, Instituto de Economia da Universidade Estadual de Campinas, 2015.

MINISTÉRIO DAS CIDADES. Plano Nacional de Habitação. Versão para Debates. Brasília, 2009.

MORAIS, Maria Piedade, KLAUSE, Cleandro, NETO, Vicente Correia Lima (orgs.). Caracterização e tipologia dos assentamentos precários: estudos de casos brasileiros. Brasília: Ipea, 2016.

NAÇÕES UNIDAS. 22 - Assentamentos informais. Documentos temáticos da Habitat III. Quito, out. 2016.

NASCIMENTO, Denise Morado et al. Programa Minha Casa Minha Vida: desafios e avanços na Região Metropolitana de Belo Horizonte. In: AMORE, Caio Santo; SCHIMBO, Lúcia Zanin; RUFINO, Maria Beatriz Cruz (orgs.). Minha casa... e a cidade? Avaliação do programa minha casa minha vida em seis estados brasileiros. Rio de Janeiro: Letra Capital, 2015.

NELKEN, David. Law in action or living law? Back to the beginning in sociology of law. Legal studies, v. 4, n. 2, p. 157-174, 1984. 
NERI, Marcelo. A nova classe média: o lado brilhante da base da pirâmide. São Paulo: Saraiva, 2011.

NIELSEN, Laura Beth. The need for multi-method approaches in empirical legal research: In: CANE, P. \& KRITZER, H. M. The Oxford Handbook of Empirical Legal Research. Oxford: Oxford University Press, 2010, p. 951-975.

OCTAVIANI, Alessandro. Recursos genéticos e desenvolvimento: os desafios furtadiano e gramsciano. 2008. Tese (Doutorado em Direito Econômico) Universidade de São Paulo, São Paulo, 2008.

OLIVEIRA, Leonardo Ferreira de; SANTOS JUNIOR, Carlos Denner dos. Inovações no setor público. In: CAVALCANTE, Pedro et al. Inovação no Setor Público: teoria, tendências e casos no Brasil, 2017, p. 33-42.

OLIVEIRA, Rinaldo de. Brasil: Lula dobra a meta de construção de casas populares. Uol Notícias, 12 fev. 2009. Disponível em: https://tvuol.uol.com.br/video/brasil-luladobra-a-meta-de-construcao-de-casas-populares-04024C1A3568C0813326. Último acesso em 04 de novembro de 2017.

PAIXÃO, Daniela. "Vamos tocar o barco pra frente", diz Lula em SP. UOL Notícias, 27 mar 2009. Disponível em http://mais.uol.com.br/view/1575mnadmi5c/vamos-tocar-obarco-pra-frente-diz-lula-em-sp-04023168C0C98326?types=A\&. Último acesso em 04 de novembro de 2017.

PAZ, Rosangela Dias Oliveira da et al. Trabalho social no Programa Minha Casa, Minha Vida: a experiência da cidade de Osasco/São Paulo. In: AMORE, Caio Santo; SCHIMBO, Lúcia Zanin; RUFINO, Maria Beatriz Cruz (orgs.). Minha casa... e a cidade? Avaliação do programa minha casa minha vida em seis estados brasileiros. Rio de Janeiro: Letra Capital, 2015.

PEQUENO, Renato; ROSA, Sara Vieira. Inserção Urbana e Segregação Espacial: análise do Programa Minha Casa Minha Vida em Fortaleza. In: AMORE, Caio Santo; SCHIMBO, Lúcia Zanin; RUFINO, Maria Beatriz Cruz (orgs.). Minha casa... e a cidade? Avaliação do programa minha casa minha vida em seis estados brasileiros. Rio de Janeiro: Letra Capital, 2015.

PIRES, A. P. Amostragem e pesquisa qualitativa: ensaio teórico e metodológico. In: POUPART, J. et. al. A pesquisa qualitativa: enfoques epistemológicos e metodológicos. Petrópolis: Vozes, 2008, p. 154-211. 
POLIS, Instituto. Subsídios para a implementação do Sistema Nacional de Habitação de Interesse Social pelos Estados e Municípios visando a promoção do direito à moradia. Novembro de 2007.

PORTAL BRASIL. Caixa inicia financiamentos da Faixa 1,5 do Programa Minha Casa Minha Vida. Portal Brasil, 25 out. 2016. Disponível em: http://www.brasil.gov.br/infraestrutura/2016/10/caixa-inicia-financiamentos-da-faixa1-5-do-programa-minha-casa-minha-vida. Último acesso dia 26 de dezembro de 2017.

Minha Casa, Minha Vida influencia os índices de desemprego. Portal Brasil, 10 jun. 2014. Disponível em: http://www.brasil.gov.br/economia-eemprego/2014/06/minha-casa-minha-vida-influencia-os-indices-de-emprego . Último acesso em 29 de novembro de 2017.

QUINTÃO, Chiara. Rezek lança projeto de 18 mil unidades na capital paulista. Valor Econômico, 21 dez 2017.2 Disponível em: http://www.valor.com.br/empresas/5234251/rezek-lanca-projeto-de-18-mil-unidades-nacapital-paulista. Último acesso em 26 de dezembro de 2017.

RIBEIRO, Silvio Cesar Lima; DANIEL, Marcelo Nakano; ABIKO, Alex. ZEIS maps: Comparing areas to be earmarked exclusively for social housing in São Paulo city. Land Use Policy, v. 58, p. 445-455, 2016.

RIZEK, Cibele Saliba; SANTO AMORE, Caio; MORENO DE CAMARGO, Camila. Política social, gestão e negócio na produção das cidades: o Programa Minha Casa Minha Vida "entidades". Caderno CRH, v. 27, n. 72, 2014.

RODRIGUES, Evaniza Lopes. A estratégia fundiária dos movimentos populares na produção autogestionária de moradia. 2013. Dissertação (mestrado) faculdade de Arquitetura e Urbanismo da Universidade de São Paulo, 2013.

RODRIGUES, Leandro de Padua. A produção habitacional do programa Minha Casa Minha Vida na região metropolitana de São Paulo. 2015. Dissertação (mestrado) - Universidade de São Paulo, 2015.

RONALD, Richard. The ideology of home ownership: Homeowner societies and the role of housing. Basingstoke; Nova York: Palgrave MacMillan, 2008.

ROLNIK, Raquel; KLINK, Jeroen. Crescimento econômico e desenvolvimento urbano: por que nossas cidades continuam tão precárias?. Novos estudosCEBRAP, n. 89, p. 89-109, 2011. 
; KLINTOWITZ, Danielle; REIS, Joyce e BISCHOF, Raphael. Como produzir moradia bem localizada com os recursos do programa Minha Casa Minha Vida? - Implementando os Instrumentos do Estatuto da Cidade. 2010. Disponível em http://web.observatoriodasmetropoles.net/planosdiretores/download/cartilha.pdf

Guerra dos lugares: a colonização da terra e da moradia na era das finanças. São Paulo: Boitempo, 2015.

(org.). Ferramentas para avaliação da inserção urbana dos empreendimentos do MCMV. Chamada MCTI/CNPq/MCidades № 11/2012, nov. 2014.

IACOVINI, Rodrigo Faria Gonçalves; KLINTOWITZ, Danielle. Habitação em municípios paulistas: construir políticas ou "rodar" programas? Revista Brasileira de Estudos Urbanos e Regionais, v. 16, n. 2, 2014.

et al.. O Programa Minha Casa Minha Vida nas regiões metropolitanas de São Paulo e Campinas: aspectos socioespaciais e segregação. Cadernos Metrópole, v. 17, n. 33, p. 127-154, 2015.

ROLNIK, Raquel.; SANTORO, Paula. Freire. Zonas Especiais de Interesse Social (ZEIS) em Cidades brasileiras: Trajetória Recente de Implementação de um instrumento de Política Fundiária. Lincoln Institute of Land Policy, 2013.

RUFINO, Maria Beatriz Cruz. Um olhar sobre a produção do PMCMV a partir de eixos analíticos. In: AMORE, Caio Santo; SCHIMBO, Lúcia Zanin; RUFINO, Maria Beatriz Cruz (orgs.). Minha casa... e a cidade? Avaliação do programa minha casa minha vida em seis estados brasileiros. Rio de Janeiro: Letra Capital, 2015.

SABATIER, Paul A. Top-down and bottom-up approaches to implementation research: a critical analysis and suggested synthesis. Journal of public policy, v. 6 , n. 1, p. 21-48, 1986.

SANTORO, Paula Freire; BORRELLI, Julia. Os desafios de produzir habitação de interesse social em São Paulo: da reserva de terra no zoneamento às contrapartidas obtidas a partir do desenvolvimento imobiliário ou das ZEIS à Cota de Solidariedade. Anais do Encontro Nacional da Anpur, v. 16, p. 1-19, 2015.

SANTORO, Paula Freire; MACEDO, Sara Messaggi. A (des) articulação dos instrumentos de planejamento urbano sob a ótica das soluções habitacionais: remover, relocar ou indenizar na Operação Urbana Consorciada Água Espraiada. 
Anais do III Encontro da Associação Nacional de Pesquisa e Pós-graduação em Arquitetura e Urbanismo. São Paulo, 2014.

SANTOS, Ângela Moulin Simões Penalva; VASQUES, Pedro Henrique Ramos Prado. Política urbana no contexto federativo brasileiro: um avanço normativo na gestão dos aglomerados urbanos/Urban policy in the federative brazilian context: a normative advance in the management of urban agglomerations. Revista de Direito da Cidade, v. 7, n. 4, p. 1771-1790, 2015.

SANTOS, Milton. Por uma economia política da cidade. O caso de São Paulo, $2^{\underline{a}}$ edição. São Paulo: EDUSP, 2012.

A urbanização desigual: a especificidade do fenômeno urbano em países subdesenvolvidos, 3aㅡ edição. São Paulo: EDUSP, 2012.

A urbanização brasileira, 5a edição. São Paulo: EDUSP, 2013.

SARAIVA, Camila, MARQUES, Eduardo. A dinâmica social das favelas da região metropolitana de São Paulo. Pensamento \& Realidade, 2007.

SARAT, Austin. Vitality amidst fragmentation: On the emergence of postrealist law and society scholarship. The Blackwell Companion to Law and Society, p. 1-11, 2007.

SECCHI, Leonardo. Políticas públicas: conceitos, esquemas de análise, casos práticos. São Paulo: Cengage Learning, 2010.

SECRETARIA DE HABITAÇÃO (SEHAB). Plano Municipal de Habitação: A experiência de São Paulo. Elisabete França e Keila Prado Costa (orgs), 2012.

. Plano Municipal de Habitação de São Paulo. Caderno para discussão pública. São Paulo, 2016.

. Balanço de governo. 2013-2016. São Paulo, 2016.

SEN, Amartya. Desenvolvimento como liberdade. São Paulo: Companhia das Letras, 2010.

SINGER, André. Os sentidos do lulismo: reforma gradual e pacto conservador. São Paulo: Companhia das Letras, 2012. 
SINGER, Paul Israel. Dominação e desigualdade: estrutura de classes e repartição da renda no Brasil. Coleção Estudos Brasileiros, v. 49. Rio de Janeiro: Paz e Terra, 1981.

SOUZA, Celina. Governos locais e gestão de políticas sociais universais. São Paulo em perspectiva, v. 18, n. 2, p. 27-41, 2004.

TANAKA, Rodrigo Minoru Hayakama. As Zonas Especiais de Interesse Social de São Paulo de 2002 a 2014: propósitos e resultados. Monografia apresentada para a matéria Avaliação da Teoria Intraurbana da Faculdade de Arquitetura e Urbanismo da USP. 2017

TATAGIBA, Luciana F. et al. Inovações participativas nas políticas habitacionais para população de baixa renda: um estudo de caso sobre o programa Minha Casa, Minha Vida-Entidades. Relatório final de Pesquisa apresentado no Programa Regional de Becas de Investigación CLACSO-ASDI 2013. Disponível em http://biblioteca.clacso.edu.ar/gsdl/collect/clacso/index/assoc/D9244.dir/Clacso_ver sao_final.pdf. Último acesso em 22 de abril de 2017.

TRUBEK, David M.; COUTINHO, Diogo R.; SCHAPIRO, Mario G. Toward a New Law and Development: New State Activism in Brazil and the Challenge for Legal Institutions. In: The World Bank Legal Review: Legal Innovation and Empowerment for Development 2012.

VILLAÇA, Flávio. O que todo cidadão precisa saber sobre habitação. Cadernos de Educação Política, v. 16. São Paulo: Global, 1986.

WINDRUM, Paul; KOCH, Per M. (Ed.). Innovation in public sector services: entrepreneurship, creativity and management. Edward Elgar Publishing, 2008.

YIN, Robert K. Estudo de caso: planejamento e métodos [recurso eletrônico], $5^{\text {a }}$ edição. Porto Alegre: Bookman, 2015. 
ANEXO 1 - Atos Normativos no âmbito federal sobre o MCMV Faixa 1 - FAR (excluindo regulamentação da CEF) 


\begin{tabular}{|c|c|c|c|c|c|c|c|c|c|}
\hline ÓRGÃO & TAG & ASSUNTO & ANO & $\begin{array}{l}\text { TIPO } \\
\text { DE } \\
\text { NOR } \\
\text { MA }\end{array}$ & $\begin{array}{l}\text { NÚM } \\
\text { ERO }\end{array}$ & EMENTA & RESUMO & $\begin{array}{c}\text { OBSERVAÇÃ } \\
0\end{array}$ & SITE \\
\hline $\begin{array}{l}\text { MINISTÉRIO DAS } \\
\text { CIDADES }\end{array}$ & $\begin{array}{l}\text { TERMO } \\
\text { DE } \\
\text { ADESÃO }\end{array}$ & $\begin{array}{c}\text { Delegação de } \\
\text { competência ao } \\
\text { secretário Nacional } \\
\text { de Habitação para } \\
\text { celebrar termos de } \\
\text { adesão }\end{array}$ & 2017 & $\begin{array}{l}\text { PORTA } \\
\text { RIA }\end{array}$ & 534 & $\begin{array}{c}\text { Dispõe sobre a delegação de } \\
\text { competência ao Secretário } \\
\text { Nacional de Habitação para } \\
\text { notificações em termos de adesão } \\
\text { firmados com Estados e } \\
\text { Municípios para execução do } \\
\text { Programa Minha Casa, Minha } \\
\text { Vida. }\end{array}$ & & & 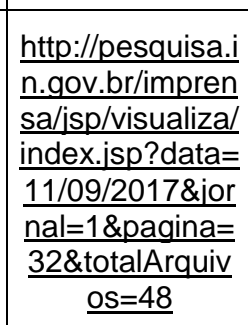 \\
\hline $\begin{array}{l}\text { MINISTÉRIO DAS } \\
\text { CIDADES }\end{array}$ & PRAZO & $\begin{array}{l}\text { Prazo para } \\
\text { apresentação de } \\
\text { propostas de } \\
\text { aquisição de } \\
\text { imóveis com } \\
\text { recursos do FAR no } \\
\text { âmbito do PNHU }\end{array}$ & 2017 & $\begin{array}{l}\text { PORTA } \\
\text { RIA }\end{array}$ & 515 & $\begin{array}{c}\text { Estabelece prazo limite para } \\
\text { apresentação de propostas para } \\
\text { aquisição de imóveis com } \\
\text { recursos advindos da } \\
\text { integralização de cotas no Fundo } \\
\text { de Arrendamento Residencial } \\
\text { (FAR), no âmbito do Programa } \\
\text { Nacional de Habitação Urbana } \\
\text { (PNHU), integrante do Programa } \\
\text { Minha Casa, Minha Vida } \\
\text { (PMCMV). }\end{array}$ & $\begin{array}{l}\text { Prazo para } \\
\text { recepcionar } \\
\text { propostas dos } \\
\text { empreendimentos. }\end{array}$ & & 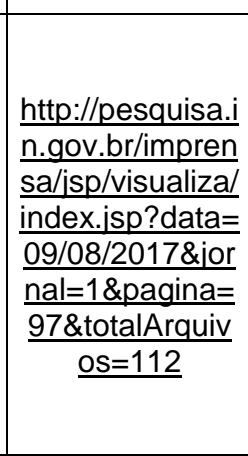 \\
\hline $\begin{array}{l}\text { MINISTÉRIO DAS } \\
\text { CIDADES }\end{array}$ & $\begin{array}{l}\text { BENEFICI } \\
\text { ÁRIOS }\end{array}$ & $\begin{array}{c}\text { Trata sobre o } \\
\text { distrato dos } \\
\text { contratos dos } \\
\text { beneficiários - FAR }\end{array}$ & 2017 & $\begin{array}{l}\text { PORTA } \\
\text { RIA }\end{array}$ & 488 & $\begin{array}{l}\text { Dispõe sobre o distrato dos } \\
\text { contratos de beneficiários de } \\
\text { unidades habitacionais produzidas } \\
\text { com recursos provenientes da } \\
\text { integralização de cotas no Fundo } \\
\text { de Arrendamento Residencial } \\
\text { (FAR), no âmbito do Programa } \\
\text { Nacional de Habitação } \\
\text { Urbana(PNHU), integrante do }\end{array}$ & $\begin{array}{c}\text { Ocorrerá rescisão } \\
\text { nos casos de } \\
\text { descumprimento } \\
\text { contratual, ocupação } \\
\text { irregular, desvio de } \\
\text { finalidade, } \\
\text { inadimplemento com } \\
\text { os pagamentos das } \\
\text { prestações da } \\
\text { compra e venda ou } \\
\end{array}$ & $\begin{array}{c}\text { Revoga a } \\
\text { Portaria } \\
606 / 2016\end{array}$ & 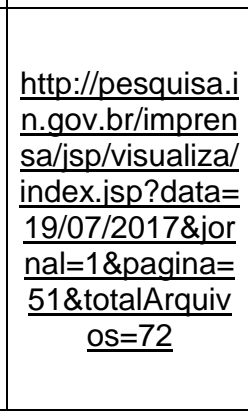 \\
\hline
\end{tabular}




\begin{tabular}{|c|c|c|c|c|c|c|c|c|}
\hline & & & & & & $\begin{array}{l}\text { Programa MinhaCasa, Minha Vida } \\
\text { (PMCMV). }\end{array}$ & $\begin{array}{l}\text { por solicitação do } \\
\text { beneficiário. }\end{array}$ & \\
\hline $\begin{array}{l}\text { MINISTÉRIO DAS } \\
\text { CIDADES }\end{array}$ & $\begin{array}{l}\text { REGULA } \\
\text { MENTO }\end{array}$ & $\begin{array}{l}\text { Condições gerais } \\
\text { para aquisição de } \\
\text { imóveis }\end{array}$ & 2017 & $\begin{array}{l}\text { PORTA } \\
\text { RIA }\end{array}$ & 472 & $\begin{array}{l}\text { Altera a Portaria no } 267 \text {, de } 22 \text { de } \\
\text { março de } 2017, \text { que dispõe sobre } \\
\text { as condições gerais para } \\
\text { aquisição de imóveis com } \\
\text { recursos advindos da } \\
\text { integralização de cotas no Fundo } \\
\text { de Arrendamento Residencial } \\
\text { (FAR), no âmbito do Programa } \\
\text { Nacional de Habitação Urbana } \\
\text { (PNHU), integrante do Programa } \\
\text { Minha Casa, Minha Vida } \\
\text { (PMCMV). }\end{array}$ & $\begin{array}{c}\text { Dá nova redação ao } \\
\text { subitem 6.5.2 do } \\
\text { Anexo I da Portaria no } \\
267 / 2017 .\end{array}$ & 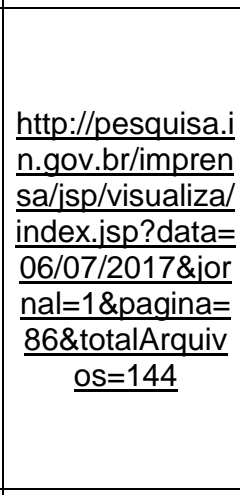 \\
\hline $\begin{array}{l}\text { MINISTÉRIO DAS } \\
\text { CIDADES }\end{array}$ & $\begin{array}{l}\text { BENEFICI } \\
\text { ÁRIOS }\end{array}$ & $\begin{array}{c}\text { Revogação a } \\
\text { Portaria № } \\
\text { 355/2017 }\end{array}$ & 2017 & $\begin{array}{l}\text { PORTA } \\
\text { RIA }\end{array}$ & 416 & $\begin{array}{l}\text { Revoga a Portaria no } 355 \text {, de } 28 \\
\text { de abril de } 2017 \text {, que regulamenta } \\
\text { a aplicação do art. } 32 \text { da Lei no } \\
\text { 13.146, de } 6 \text { de julho de } 2015 \text { nas } \\
\text { operações de crédito contratadas } \\
\text { no âmbito dos programas } \\
\text { habitacionais, públicos ou } \\
\text { subsidiados com recursos } \\
\text { públicos, geridos pelo Ministério } \\
\text { das Cidades. }\end{array}$ & $\begin{array}{c}\text { A Portaria revogada } \\
\text { tratava da prioridade } \\
\text { de PNE na aquisição } \\
\text { de imóveis, nos } \\
\text { programas } \\
\text { habitacionais. A } \\
\text { Portaria foi revogada } \\
\text { por recomendação do } \\
\text { Ministério Público, no } \\
\text { processo no } \\
\text { 80000.012842/2017- } \\
08 \text {. }\end{array}$ & 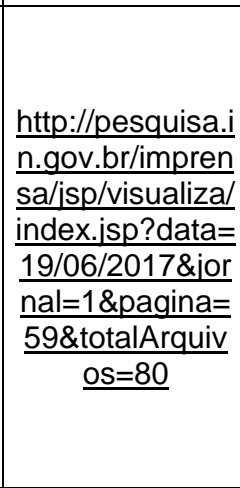 \\
\hline
\end{tabular}




\begin{tabular}{|c|c|c|c|c|c|c|c|c|}
\hline $\begin{array}{l}\text { MINISTÉRIO DAS } \\
\text { CIDADES }\end{array}$ & $\begin{array}{l}\text { RECURS } \\
\text { OS }\end{array}$ & $\begin{array}{l}\text { Divulgação das } \\
\text { propostas } \\
\text { habilitadas para } \\
\text { aquisição de } \\
\text { imóveis }\end{array}$ & 2017 & $\begin{array}{l}\text { PORTA } \\
\text { RIA }\end{array}$ & 406 & \begin{tabular}{|} 
Divulga propostas habilitadas para \\
aquisição de imóveis com \\
recursos advindos da \\
integralização de cotas no Fundo \\
de Arrendamento Residencial \\
(FAR), no âmbito do Programa \\
Nacional de Habitação Urbana \\
(PNHU), integrante do Programa \\
Minha Casa, Minha Vida \\
(PMCMV). \\
\end{tabular} & $\begin{array}{c}\text { Nos termos da } \\
\text { Portaria } 267 / 2017 . \\
{ }^{*} \text { Mostra as unidades } \\
\text { habitacionais de SP. }\end{array}$ & 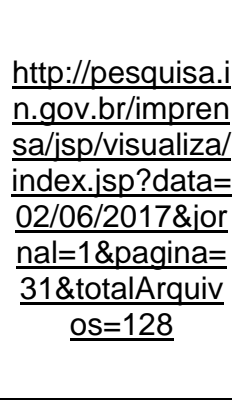 \\
\hline $\begin{array}{l}\text { MINISTÉRIO DAS } \\
\text { CIDADES }\end{array}$ & $\begin{array}{l}\text { INFRAES } \\
\text { TRUTURA }\end{array}$ & $\begin{array}{c}\text { Energia solar no } \\
\text { Programa Minha } \\
\text { Casa Minha Vida - } \\
\text { PMCMV }\end{array}$ & 2017 & $\begin{array}{l}\text { PORTA } \\
\text { RIA }\end{array}$ & 374 & $\begin{array}{c}\text { Institui Grupo de Trabalho com o } \\
\text { objetivo de estudar a viabilidade de se } \\
\text { aproveitar energia solar no Programa } \\
\text { Minha Casa Minha Vida - PMCMV. }\end{array}$ & $\begin{array}{l}\text { Institui Grupo de } \\
\text { Trabalho com o objetivo } \\
\text { de estudar a viabilidade } \\
\text { de se aproveitar energia } \\
\text { solar no Programa } \\
\text { Minha Casa Minha Vida } \\
\text { - PMCMV. }\end{array}$ & $\begin{array}{l}\text { http://pesquisa.i } \\
\text { n.gov.br/impren } \\
\text { sa/jsp/visualiza/ } \\
\text { index.jsp?data }= \\
18 / 05 / 2017 \& \text { jor } \\
\text { nal=2\&pagina }= \\
\text { 51\&totalArquiv } \\
\text { os }=72\end{array}$ \\
\hline $\begin{array}{l}\text { MINISTÉRIO DAS } \\
\text { CIDADES }\end{array}$ & $\begin{array}{l}\text { REGULA } \\
\text { MENTO }\end{array}$ & $\begin{array}{l}\text { Condições gerais } \\
\text { para aquisição de } \\
\text { imóveis }\end{array}$ & 2017 & $\begin{array}{l}\text { RETIFI } \\
\text { CAÇÃ } \\
O\end{array}$ & 342 & \begin{tabular}{|c|} 
Na Portaria no 267, de 22 de março de \\
2017, com a redação dada pela \\
Portaria no 342, de 24 de abril de \\
2017, publicada no DOU de \\
25//04/2017, Seção 1, na página 45, \\
na alínea c do subitem 8.1.1 do Anexo \\
I, onde se lê:" c) Somatório da \\
contratação no município objeto da \\
proposta inferior a 20\% (trinta por \\
cento) do déficit habitacional urbano, \\
considerando empreendimentos \\
produzidos com recursos do Fundo de \\
Desenvolvimento Social (FDS), da \\
Oferta Pública de Recursos e do FAR, \\
desconsideradas as operações \\
vinculadas ao PAC;" ; leia-se: "c) \\
Somatório da contratação no \\
munićpio objeto da proposta inferior a \\
50\% (cinquenta por cento) do déficit \\
habitacional urbano, considerando \\
empreendimentos produzidos com \\
\end{tabular} & $\begin{array}{l}\text { Traz modificação na } \\
\text { alínea c do subitem } \\
8.1 .1 \text { do Anexo I e no } \\
\text { subitem } 9.4 .1 \text { do Anexo } \\
\text { I da Portaria } 342 / 2017 .\end{array}$ & 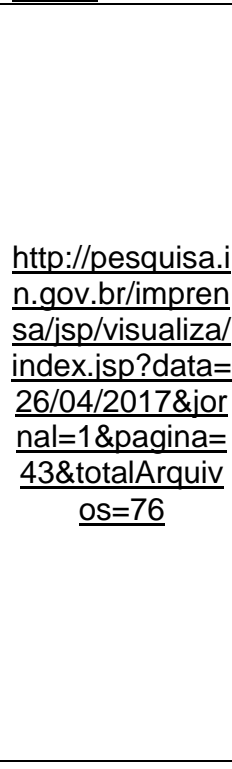 \\
\hline
\end{tabular}




\begin{tabular}{|c|c|c|c|c|c|c|c|c|}
\hline & & & & & & $\begin{array}{c}\text { recursos do Fundo de } \\
\text { Desenvolvimento Social (FDS), da } \\
\text { Oferta Pública de Recursos e do FAR, } \\
\text { desconsideradas as operações } \\
\text { vinculadas ao PAC;" ; e no subitem } \\
\text { 9.4.1 do Anexo I, onde se lê: "9.4.1 A } \\
\text { Secretaria Nacional de Habitação } \\
\text { poderá admitir a prorrogação, por } \\
\text { igual período, do prazo previsto no } \\
\text { item 9.5, baseado em solicitação } \\
\text { fundamentada do Gestor Operacional } \\
\text { do PMCMV, motivada por dificuldades } \\
\text { na obtenção do licenciamento } \\
\text { ambiental necessário." ; leia-se: "9.4.1 } \\
\text { A Secretaria Nacional de Habitação } \\
\text { poderá admitir a prorrogação, por } \\
\text { igual período, do prazo previsto no } \\
\text { item 9.4, baseado em solicitação } \\
\text { fundamentada do Gestor Operacional } \\
\text { do PMCMV, motivada por dificuldades } \\
\text { na obtenção do licenciamento } \\
\text { ambiental necessário." . }\end{array}$ & & \\
\hline $\begin{array}{l}\text { MINISTÉRIO DAS } \\
\text { CIDADES }\end{array}$ & $\begin{array}{l}\text { REGULA } \\
\text { MENTO }\end{array}$ & $\begin{array}{l}\text { Condições gerais } \\
\text { para aquisição de } \\
\text { imóveis }\end{array}$ & 2017 & $\mid \begin{array}{c}\text { PORTA } \\
\text { RIA }\end{array}$ & 342 & $\begin{array}{c}\text { Altera a Portaria no } 267 \text {, de } 22 \text { de } \\
\text { março de } 2017 \text {, que dispõe sobre } \\
\text { as condições gerais para } \\
\text { aquisição de imóveis com } \\
\text { recursos advindos da } \\
\text { integralização de cotas no Fundo } \\
\text { de Arrendamento Residencial } \\
\text { (FAR), no âmbito do Programa } \\
\text { Nacional de Habitação Urbana } \\
\text { (PNHU), integrante do Programa } \\
\text { Minha Casa, Minha Vida } \\
\text { (PMCMV). }\end{array}$ & $\begin{array}{c}\text { Traz alteração ao } \\
\text { Anexo I - Valores } \\
\text { máximos de } \\
\text { aquisição das } \\
\text { unidades, no item } 8 \text { - } \\
\text { Enquadramento e } \\
\text { seleção de propostas, } \\
\text { no item } 9 \text { - Requisitos } \\
\text { para contratação, } \\
\text { item } 10 \text { - } \\
\text { Monitoramento. No } \\
\text { Anexo II - Operações } \\
\text { vinculadas a } \\
\text { intervenções no } \\
\text { âmbito do programa } \\
\text { de aceleração do } \\
\text { crescimento. No }\end{array}$ & 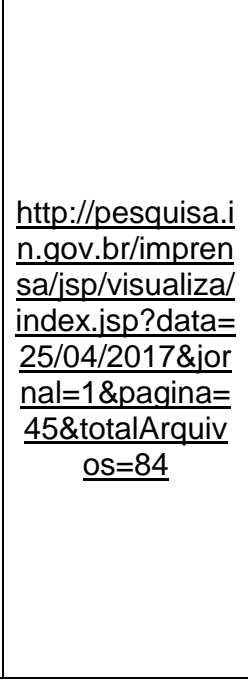 \\
\hline
\end{tabular}




\begin{tabular}{|c|c|c|c|c|c|c|c|c|c|}
\hline & & & & & & & $\begin{array}{l}\text { anexo III - Edificação } \\
\text { de equipamento } \\
\text { públicos de educação } \\
\text { complementares a } \\
\text { habitação (diretrizes). } \\
\text { No Anexo IV - Gestão } \\
\text { condominial e } \\
\text { patrimonial. }\end{array}$ & & \\
\hline $\begin{array}{l}\text { MINISTÉRIO DAS } \\
\text { CIDADES }\end{array}$ & $\begin{array}{l}\text { INFRAES } \\
\text { TRUTURA }\end{array}$ & \begin{tabular}{|c|} 
Diretriz para \\
elaboração de \\
projeto, \\
especificações da \\
unidade \\
habitacional e \\
especificações \\
urbanísticas - FAR e \\
FDS
\end{tabular} & 2017 & $\begin{array}{c}\text { PORTA } \\
\text { RIA }\end{array}$ & 269 & $\begin{array}{c}\text { Dispõe sobre as diretrizes para a } \\
\text { elaboração de projetos e aprova } \\
\text { as especificações mínimas da } \\
\text { unidade habitacional e as } \\
\text { especificações urbanísticas dos } \\
\text { empreendimentos destinados à } \\
\text { aquisição e alienação com } \\
\text { recursos advindos da } \\
\text { integralização de cotas no Fundo } \\
\text { de Arrendamento Residencial - } \\
\text { FAR, e contratação de operações } \\
\text { com recursos transferidos ao } \\
\text { Fundo de Desenvolvimento Social } \\
\text { - FDS, no âmbito do Programa } \\
\text { Minha Casa, Minha Vida - P M C } \\
\text { M V. }\end{array}$ & $\begin{array}{l}\text { Trata das diretrizes } \\
\text { para elaboração de } \\
\text { projetos, forma de } \\
\text { apresentação e } \\
\text { enquadramento, } \\
\text { requisitos para } \\
\text { contratação. Traz } \\
\text { Anexo com as } \\
\text { condições mínimas } \\
\text { das unidades } \\
\text { habitacionais. Traz } \\
\text { Anexo com as } \\
\text { especificações } \\
\text { urbanísticas dos } \\
\text { empreendimentos. }\end{array}$ & $\begin{array}{c}\text { Revoga a } \\
\text { Portaria } \\
\text { 146/2016. }\end{array}$ & 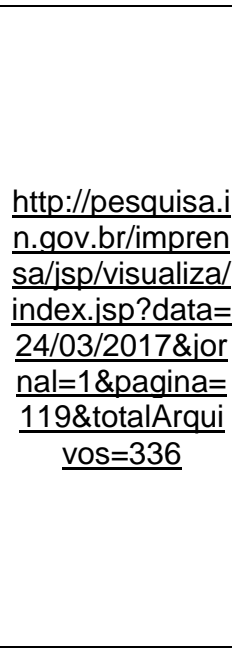 \\
\hline $\begin{array}{l}\text { MINISTÉRIO DAS } \\
\text { CIDADES }\end{array}$ & $\begin{array}{l}\text { REGULA } \\
\text { MENTO }\end{array}$ & $\begin{array}{l}\text { Condições gerais } \\
\text { para aquisição de } \\
\text { imóveis }\end{array}$ & 2017 & $\begin{array}{l}\text { PORTA } \\
\text { RIA }\end{array}$ & 267 & $\begin{array}{c}\text { Dispõe sobre as condições gerais } \\
\text { para aquisição de imóveis com } \\
\text { recursos advindos da } \\
\text { integralização de cotas no Fundo } \\
\text { de Arrendamento Residencial } \\
\text { (FAR), no âmbito do Programa } \\
\text { Nacional de Habitação Urbana } \\
\text { (PNHU), integrante do Programa } \\
\text { Minha Casa, Minha Vida } \\
\text { (PMCMV). }\end{array}$ & $\begin{array}{c}\text { Trata das condições } \\
\text { gerais para aquisição } \\
\text { de UH, Participantes } \\
\text { e } \\
\text { atribuições, Empresa } \\
\text { s do setor da } \\
\text { construção civil, Área } \\
\text { de abrangência, } \\
\text { Origem e alocação } \\
\text { dos recursos, Plano } \\
\text { de contratação e }\end{array}$ & \begin{tabular}{|c|} 
O subitem 6.5.2, \\
do Anexo I, tem \\
nova redação \\
pela \\
Portaria $472 / 201$ \\
$7 / /$ Nova \\
redação para o \\
Anexo I - Valores \\
máximos de \\
aquisição das \\
unidades, no \\
\end{tabular} & 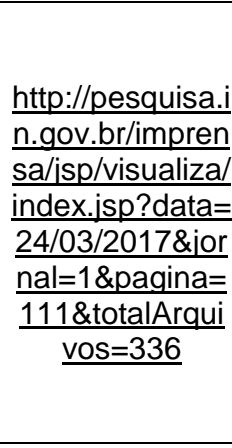 \\
\hline
\end{tabular}


meta física, Valores máximos de aquisição das

unidades, Processo de seleção de

empresa construtora

em terreno doado ao

FAR, Enquadramento e seleção de

propostas, Requisitos

para contratação e

Monitoramento. item 8 -

Enquadramento e seleção de

propostas, no

item 9 -

Requisitos para ontratação, item 10

Monitoramento.

No Anexo II -

Operações

vinculadas a

intervenções no

âmbito do

programa de

aceleração do

crescimento. No

anexo III -

Edificação de

equipamento

públicos de

educação

complementares

a habitação

(diretrizes). No

Anexo IV -

Gestão

condominial e

patrimonial dada

pela Portaria

342/2017.

[Revoga Portaria 158/201.] 


\begin{tabular}{|c|c|c|c|c|c|c|c|c|c|}
\hline $\begin{array}{l}\text { MINISTÉRIO DAS } \\
\text { CIDADES }\end{array}$ & $\begin{array}{l}\text { BENEFICI } \\
\text { ÁRIOS }\end{array}$ & $\begin{array}{l}\text { Dispensa do } \\
\text { sorteio/microcefalia }\end{array}$ & 2016 & $\begin{array}{c}\text { RETIFI } \\
\text { CAÇÃ } \\
O\end{array}$ & 321 & $\begin{array}{c}\text { Na Portaria no } 321 \text {, de } 14 \text { de julho } \\
\text { de } 2016 \text {, publicada no DOU de } 15 \\
\text { de julho de } 2016 \text {, Seção } 1 \text {, página } \\
54 \text {, no art. 10, onde se lê: "d) } \\
\text { possua membro da família, } \\
\text { vivendo sob sua dependência, } \\
\text { com microcefalia, devidamente } \\
\text { comprovada com a apresentação } \\
\text { de atestado médico.", leia-se: "e) } \\
\text { possua membro da família, } \\
\text { vivendo sob sua dependência, } \\
\text { com microcefalia, devidamente } \\
\text { comprovada com a apresentação } \\
\text { de atestado médico.". }\end{array}$ & $\begin{array}{c}\text { Trocou apenas a } \\
\text { enumeração dos } \\
\text { pontos de "D" para } \\
\text { "E". }\end{array}$ & & 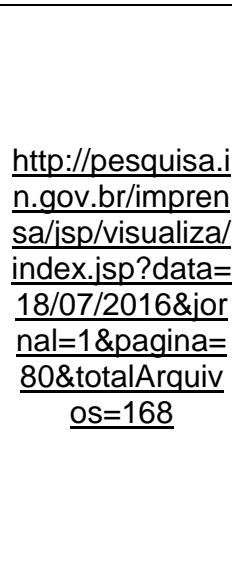 \\
\hline $\begin{array}{l}\text { MINISTÉRIO DAS } \\
\text { CIDADES }\end{array}$ & $\begin{array}{l}\text { BENEFICI } \\
\text { ÁRIOS }\end{array}$ & $\begin{array}{l}\text { Dispensa do } \\
\text { sorteio/microcefalia }\end{array}$ & 2016 & $\begin{array}{l}\text { PORTA } \\
\text { RIA }\end{array}$ & 321 & $\begin{array}{c}\text { Dá nova redação ao Manual de } \\
\text { Instruções para Seleções de } \\
\text { Beneficiários no âmbito do } \\
\text { Programa Minha Casa, Minha } \\
\text { Vida, } \\
\text { aprovado pela Portaria no } 163 \text {, de } \\
6 \text { de maio de } 2016 \text {, do Ministério } \\
\text { das Cidades. }\end{array}$ & $\begin{array}{c}\text { Altera o Capitulo I, } \\
\text { item 4.9, da Portaria } \\
\text { 163/2016. }\end{array}$ & $\begin{array}{l}\text { Dispensa do } \\
\text { sorteio os } \\
\text { candidatos que } \\
\text { tenham algum } \\
\text { membro da } \\
\text { família com } \\
\text { microcefalia. }\end{array}$ & $\begin{array}{l}\text { http://pesquisa.i } \\
\text { n.gov.br/impren } \\
\text { sa/jsp/visualiza/ } \\
\text { index.jsp?data }= \\
\text { 15/07/2016\&:or } \\
\text { nal=1\&pagina }= \\
\text { 54\&total/Arquiv } \\
\text { os }=168\end{array}$ \\
\hline $\begin{array}{l}\text { MINISTÉRIO DAS } \\
\text { CIDADES }\end{array}$ & $\begin{array}{l}\text { BENEFICI } \\
\text { ÁRIOS }\end{array}$ & $\begin{array}{l}\text { Aprova Manual de } \\
\text { Instrução para } \\
\text { Seleção de } \\
\text { Beneficiários }\end{array}$ & 2016 & $\begin{array}{l}\text { PORTA } \\
\text { RIA }\end{array}$ & 163 & $\begin{array}{c}\text { Institui o Sistema Nacional de } \\
\text { Cadastro Habitacional (SNCH) e } \\
\text { aprova o Manual de Instruções } \\
\text { para Seleção de Beneficiários } \\
\text { do Programa Nacional de } \\
\text { Habitação Urbana (PNHU), no } \\
\text { âmbito do Programa Minha Casa, } \\
\text { Minha Vida (PMCMV). }\end{array}$ & $\begin{array}{c}\text { Revoga a Portaria } \\
\text { 412/2015. Ver } \\
\text { Manual de } \\
\text { Instruções. }\end{array}$ & & 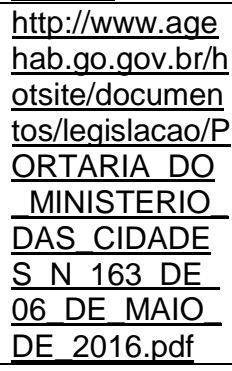 \\
\hline
\end{tabular}




\begin{tabular}{|c|c|c|c|c|c|c|c|c|c|}
\hline $\begin{array}{l}\text { MINISTÉRIO DAS } \\
\text { CIDADES / DA } \\
\text { FAZENDA/ } \\
\text { PLANEJAMENTO, } \\
\text { ORCAMENTO E } \\
\text { GESTAO }\end{array}$ & $\begin{array}{l}\text { BENEFICI } \\
\text { ÁRIOS }\end{array}$ & $\begin{array}{l}\text { Regulamentação dos } \\
\text { recursos }\end{array}$ & 2016 & $\begin{array}{c}\text { PORTAR } \\
\text { IA } \\
\text { INTERMI } \\
\text { NISTERI } \\
\text { AL }\end{array}$ & 99 & $\begin{array}{c}\text { Dispõe sobre as operações com } \\
\text { recursos advindos da } \\
\text { integralização de cotas do Fundo } \\
\text { de Arrendamento Residencial } \\
\text { (FAR), contratadas no âmbito do } \\
\text { Programa Nacional de Habitação } \\
\text { Urbana (PNHU), integrante do } \\
\text { Programa Minha Casa, Minha } \\
\text { Vida (PMCMV). }\end{array}$ & $\begin{array}{l}\text { Trata dos requisitos } \\
\text { de enquadramento } \\
\text { dos beneficiários, do } \\
\text { valor da subvenção } \\
\text { econômica e da } \\
\text { participação } \\
\text { financeira dos } \\
\text { beneficiários. }\end{array}$ & & $\begin{array}{l}\frac{\mathrm{http}: / / \text { pesquisa.in. }}{\text { gov.br/imprensa/i }} \\
\text { sp/visualiza/index } \\
\frac{\text { ssp?data }=31 / 03 /}{2016 \& \text { jornal }=1 \& \mathrm{p}} \\
\frac{\text { agina }=53 \& \text { total/Ar }}{\text { quivos }=144}\end{array}$ \\
\hline $\begin{array}{l}\text { MINISTÉRIO } \\
\text { DAS CIDADES }\end{array}$ & $\begin{array}{l}\text { BENEFICI } \\
\text { ÁRIOS }\end{array}$ & $\begin{array}{l}\text { Seleção de } \\
\text { Beneficiários }\end{array}$ & 2014 & $\begin{array}{l}\text { PORTA } \\
\text { RIA }\end{array}$ & 829 & $\begin{array}{c}\text { Dá nova redação à Portaria } n^{\circ} \\
595 / 2013, \text { do Ministério das } \\
\text { Cidades, que dispõe sobre os } \\
\text { parâmetros de priorização e sobre } \\
\text { o processo de seleção dos } \\
\text { beneficiários do Programa } \\
\text { Minha Casa, Minha Vida - P M C } \\
\text { M V. }\end{array}$ & $\begin{array}{c}\text { Nova redação para o } \\
\text { item 4.2.3 (a,b,c,d) da } \\
\text { Portaria 595/2013. }\end{array}$ & & $\begin{array}{l}\frac{\frac{\text { http://pesquisa.i }}{\text { n.gov.br/impren }}}{\frac{\text { sa/jsp/visualiza/ }}{\text { index.jsp?data }=}} \\
\frac{02 / 01 / 2015 \& \text { jor }}{\text { nal=1\&pagina }=} \\
\frac{\underline{\text { 91\&totalArquiv }}}{\underline{\text { os }=128}}\end{array}$ \\
\hline $\begin{array}{l}\text { MINISTÉRIO DAS } \\
\text { CIDADES }\end{array}$ & $\begin{array}{l}\text { BENEFICI } \\
\text { ÁRIOS }\end{array}$ & $\begin{array}{l}\text { Priorização de } \\
\text { Beneficiários }\end{array}$ & 2013 & $\begin{array}{l}\text { PORTA } \\
\text { RIA }\end{array}$ & 595 & $\begin{array}{c}\text { Dispõe sobre os parâmetros de } \\
\text { priorização } \\
\text { e sobre o processo de seleção } \\
\text { dos beneficiários } \\
\text { do Programa Minha Casa, Minha } \\
\text { Vida - PMCMV. }\end{array}$ & $\begin{array}{l}\text { Trata dos objetivos, } \\
\text { do cadastro de } \\
\text { candidatos, critérios e } \\
\text { priorização de } \\
\text { candidatos, do } \\
\text { processo de seleção, } \\
\text { CADunico, relação de } \\
\text { candidatos, verificaçã } \\
\text { o de informações. } \\
\end{array}$ & $\begin{array}{c}\text { Revoga a } \\
\text { Portaria } \\
610 / 2011 .\end{array}$ & 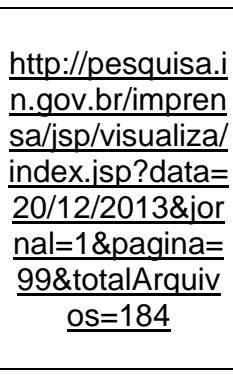 \\
\hline $\begin{array}{l}\text { MINISTÉRIO DAS } \\
\text { CIDADES }\end{array}$ & $\begin{array}{l}\text { REGULA } \\
\text { MENTO }\end{array}$ & $\begin{array}{l}\text { Alienação de } \\
\text { imóveis }\end{array}$ & 2013 & $\begin{array}{l}\text { PORTA } \\
\text { RIA }\end{array}$ & 355 & $\begin{array}{c}\text { Dispõe sobre a alienação de } \\
\text { imóveis adquiridos com recursos } \\
\text { do Fundo de Arrendamento } \\
\text { Residencial - FAR, no âmbito do } \\
\text { Programa Nacional de Habitação } \\
\text { Urbana - PNHU, integrante do } \\
\text { Programa Minha Casa, Minha } \\
\text { Vida - PMCMV, nas condições em } \\
\text { que especifica. }\end{array}$ & $\begin{array}{l}\text { Trata das condições } \\
\text { para a Caixa } \\
\text { Econômica alienar } \\
\text { imóveis } \\
\text { remanescentes. }\end{array}$ & & 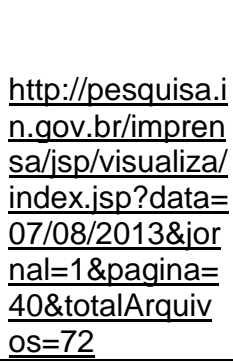 \\
\hline
\end{tabular}




\begin{tabular}{|c|c|c|c|c|c|c|c|c|c|}
\hline $\begin{array}{l}\text { MINISTÉRIO DAS } \\
\text { CIDADES }\end{array}$ & ESTADOS & Termo de adesão & 2013 & $\begin{array}{l}\text { PORTA } \\
\text { RIA }\end{array}$ & 24 & $\begin{array}{c}\text { Dispõe sobre a divulgação, } \\
\text { publicidade e identidade visual do } \\
\text { Programa Minha Casa, Minha } \\
\text { Vida - PMCMV, e dá outras } \\
\text { providências. // Fica instituído, na } \\
\text { forma do Anexo, o Termo de } \\
\text { Adesão ao Programa Minha Casa, } \\
\text { Minha Vida - PMCMV, } \\
\text { instrumento que objetiva regular a } \\
\text { participação dos estados, Distrito } \\
\text { Federal e municípios no âmbito do } \\
\text { referido programa. } \\
\end{array}$ & \begin{tabular}{|c|} 
Trata do Termo de \\
Adesão entre a \\
União, os Estados e \\
Municípios (Programa \\
Minha Casa Minha \\
Vida).
\end{tabular} & $\begin{array}{c}\text { Revoga Anexo } \\
\text { VI da Portara } \\
465 / 2011\end{array}$ & $\begin{array}{l}\frac{\text { http://www.cida }}{\text { des.gov.br/ima }} \\
\frac{\text { ges/stories/Arg }}{\text { uivosSNH/Arqu }} \\
\frac{\text { ivosPDF/Portari }}{\text { as/PORTARIA }} \\
\frac{\text { MCIDADES 02 }}{4-} \\
\frac{2013 \text { PMCM }}{\text { V Termo Ades }} \\
\frac{\text { ao Publicidade }}{. \text { pdf }} \\
\end{array}$ \\
\hline $\begin{array}{l}\text { MINISTÉRIO DAS } \\
\text { CIDADES }\end{array}$ & $\begin{array}{l}\text { RECURS } \\
\text { OS }\end{array}$ & $\begin{array}{c}\text { Desautoriza a Caixa } \\
\text { Econômica a usar } \\
\text { recursos do } \\
\text { FAR/FDS enquanto } \\
\text { não constar no } \\
\text { orçamento fiscal e } \\
\text { da seguridade } \\
\text { social. }\end{array}$ & 2016 & $\begin{array}{l}\text { INSTR } \\
\text { UCAO } \\
\text { NORM } \\
\text { ATIVA }\end{array}$ & 24 & $\begin{array}{c}\text { Dispõe sobre a vedação da } \\
\text { realização de operaçôs de } \\
\text { financiamento com recurso do } \\
\text { Fundo de Garantia por Tempo de } \\
\text { Serviço - FGTS, no âmbito do } \\
\text { Programa Minha Casa, Minha } \\
\text { Vida. }\end{array}$ & \begin{tabular}{|} 
Desautoriza a Caixa \\
Econômica a usar \\
recursos do FAR/FDS \\
enquanto não constar \\
no orçamento fiscal e \\
da seguridade social.
\end{tabular} & & $\begin{array}{l}\frac{\text { http://pesquisa.i }}{\text { n.gov.br/impren }} \\
\frac{\text { sa/jsp/visualiza/ }}{\text { index.jsp?data }=} \\
\frac{26 / 09 / 2016 \& \text { jor }}{\text { nal=1\&pagina }=} \\
\frac{\frac{\text { nalotal/Arquiv }}{\text { 99\&total }}}{\underline{\text { os }=132}}\end{array}$ \\
\hline
\end{tabular}


ANEXO 2 - Atos Normativos no âmbito federal sobre o MCMV Faixa 1 FDS (excluindo regulamentação da CEF) 


\begin{tabular}{|c|c|c|c|c|c|c|c|c|c|}
\hline ORGÃO & TAG & $\begin{array}{c}\text { ASSUNT } \\
0\end{array}$ & ANO & $\begin{array}{l}\text { TIPO DE } \\
\text { NORMA }\end{array}$ & $\begin{array}{c}\text { NÚME } \\
\text { RO }\end{array}$ & EMENTA & RESUMO & OBSERVAÇÃO & SITE \\
\hline $\begin{array}{l}\text { MINISTÉRIO } \\
\text { DAS } \\
\text { CIDADES }\end{array}$ & $\begin{array}{c}\text { REGULAM } \\
\text { ENTO }\end{array}$ & $\begin{array}{l}\text { Público- } \\
\text { alvo, } \\
\text { tipologia e } \\
\text { enquadra } \\
\text { mento de } \\
\text { propostas }\end{array}$ & 2017 & $\begin{array}{c}\text { INSTRUÇÃ } \\
\text { O } \\
\text { NORMATIV } \\
\text { A }\end{array}$ & 18 & $\begin{array}{l}\text { Dá nova redação à } \\
\text { Instrução } \\
\text { Normativa no } 14, \\
\text { de } 22 \text { de março de } \\
2017 \text {, que } \\
\text { regulamenta o } \\
\text { Programa Minha } \\
\text { Casa, Minha Vida - } \\
\text { Entidades - } \\
\text { PMCMV-E }\end{array}$ & \begin{tabular}{|c|} 
Traz nova redação \\
sobre o Público Alvo \\
(Anexo I), Tipologia \\
(Anexo II), \\
Enquadramento de \\
Propostas (Anexo III) \\
da Instrucao Normativa \\
$14 / 2017$.
\end{tabular} & $\begin{array}{c}\text { Nova redação para } \\
\text { Instrução Normativa } \\
14 / 2017 .\end{array}$ & 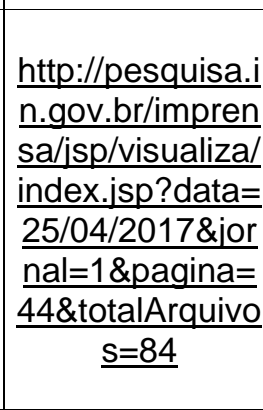 \\
\hline $\begin{array}{l}\text { MINISTÉRIO } \\
\text { DAS } \\
\text { CIDADES }\end{array}$ & $\begin{array}{l}\text { REGULAM } \\
\text { ENTO }\end{array}$ & $\begin{array}{c}\text { Regula o } \\
\text { Programa } \\
\text { Minha } \\
\text { Casa } \\
\text { Minha } \\
\text { Vida - } \\
\text { Entidades }\end{array}$ & 2017 & $\begin{array}{c}\text { INSTRUÇÃ } \\
\text { O } \\
\text { NORMATIV } \\
\text { A }\end{array}$ & 14 & $\begin{array}{c}\text { Regulamenta o } \\
\text { Programa Minha } \\
\text { Casa, Minha Vida - } \\
\text { Entidades - } \\
\text { PMCMV-E. }\end{array}$ & \begin{tabular}{|c|} 
Participantes e \\
atribuições, origem dos \\
recursos, público alvo, \\
modalidade de \\
financiamento, regime \\
de construção, valor da \\
operação, enquadrame \\
nto e solução de \\
propostas. \\
\end{tabular} & $\begin{array}{c}\text { Revoga o art. } 1^{0} \text { e } \\
\text { Anexos da Instrução } \\
\text { Normativa } n^{\circ} 39 / 2014 \text {. }\end{array}$ & 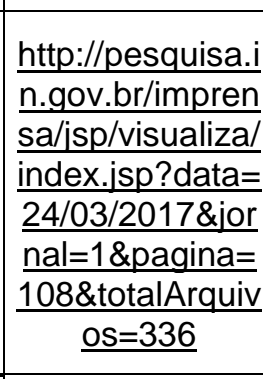 \\
\hline $\begin{array}{l}\text { MINISTÉRIO } \\
\text { DAS } \\
\text { CIDADES }\end{array}$ & $\begin{array}{c}\text { BENEFICI } \\
\text { ÁRIOS }\end{array}$ & $\begin{array}{c}\text { Enquadra } \\
\text { mento de } \\
\text { beneficiári } \\
\text { os, } \\
\text { subvenção } \\
\text { econômica } \\
\text { participaçã } \\
\text { o } \\
\text { financeira }\end{array}$ & 2016 & $\begin{array}{l}\text { PORTARIA } \\
\text { INTERMINI } \\
\text { STERIAL }\end{array}$ & 96 & $\begin{array}{l}\text { Dispõe sobre as } \\
\text { operações com } \\
\text { recursos } \\
\text { transferidos ao } \\
\text { Fundo de } \\
\text { Desenvolvimento } \\
\text { Social (FDS), } \\
\text { contratadas no } \\
\text { âmbito do } \\
\text { Programa } \\
\text { Nacional de } \\
\text { Habitação Urbana } \\
\text { (PNHU), integrante } \\
\text { do Programa }\end{array}$ & \begin{tabular}{|c|} 
Esta Portaria \\
regulamenta os \\
requisitos de \\
enquadramento dos \\
beneficiários; o valor de \\
subvenção econômica \\
e a participação \\
financeira dos \\
beneficiários. Tem o \\
objetivo de atender \\
famílias com renda \\
bruta mensal de até $\mathrm{R} \$$ \\
$1.800,00$ (um mil $\mathrm{e}$ \\
oitocentos reais),
\end{tabular} & $\begin{array}{l}\text { Revoga a Portaria } \\
\text { Interministerial no } \\
464 / 2011 .\end{array}$ & $\begin{array}{l}\frac{\text { http://pesquisa.i }}{\text { n.gov.br/impren }} \\
\frac{\text { sa/jsp/visualiza/ }}{\text { index.jsp?data }=} \\
\frac{31 / 03 / 2016 \& \text { or }}{\text { nal=1\&pagina }=} \\
\frac{\underline{52 \& \text { totalArquivo }}}{\underline{s=144}}\end{array}$ \\
\hline
\end{tabular}




\begin{tabular}{|c|c|c|c|c|c|c|c|c|c|}
\hline & & & & & & $\begin{array}{c}\text { Minha } \\
\text { Casa, Minha Vida } \\
\text { (PMCMV), para os } \\
\text { fins } \\
\text { que especifica. }\end{array}$ & \begin{tabular}{|c|} 
admitindo-se até $\mathrm{R} \$$ \\
$2.350,00$ (dois mil, \\
trezentos e cinquenta \\
reais) para até $10 \%$ \\
(dez por cento) das \\
famílias atendidas em \\
cada empreendimento \\
com as condições \\
elencadas na Portaria. \\
Contem tabela com o \\
valor das prestações \\
mensais. \\
\end{tabular} & & \\
\hline $\begin{array}{l}\text { MINISTÉRIO } \\
\text { DAS } \\
\text { CIDADES }\end{array}$ & $\begin{array}{l}\text { REGULAM } \\
\text { ENTO }\end{array}$ & $\begin{array}{c}\text { Nova } \\
\text { Redação }\end{array}$ & 2016 & $\begin{array}{c}\text { INSTRUÇÃ } \\
\text { O } \\
\text { NORMATIV } \\
\text { A }\end{array}$ & 9 & \begin{tabular}{|c|} 
Dá nova redação à \\
Instrução \\
Normativa $n^{\circ} 39$, \\
de 19 de \\
dezembro de \\
2014, do \\
Ministério das \\
Cidades, que \\
regulamenta o \\
Programa Minha \\
Casa, Minha \\
Vida - Entidades \\
(PMCMV-E).
\end{tabular} & $\begin{array}{c}\text { Nova redação para } \\
\text { composição do valor do } \\
\text { investimento, diretrizes } \\
\text { para elaboração de } \\
\text { projeto, qualifica as } \\
\text { propostas (Anexo IV), } \\
\text { fluxo operacional, } \\
\text { Instrumento } \\
\text { convocatório, } \\
\text { Pontuação, divulgação } \\
\text { dos resultados, Anexo } \\
\text { III. }\end{array}$ & $\begin{array}{c}\text { IN baseada na } \\
\text { resolução 200/2014 } \\
\text { (Resolução revogada). }\end{array}$ & $\begin{array}{l}\frac{\text { http://pesquisa.i }}{\text { n.gov.br/impren }} \\
\frac{\text { sa/isp/visualiza/ }}{\text { index.jsp?data }=} \\
\frac{29 / 04 / 2016 \& \text { or }}{\text { nal=1\&pagina }=} \\
\frac{\text { n3\&totalArquivo }}{\underline{\text { s=256 }}}\end{array}$ \\
\hline $\begin{array}{c}\text { CONSELHO } \\
\text { CURADOR } \\
\text { DO FUNDO } \\
\text { DE } \\
\text { DESENVOLV } \\
\text { IMENTO } \\
\text { SOCIAL }\end{array}$ & $\begin{array}{l}\text { REGULAM } \\
\text { ENTO }\end{array}$ & $\begin{array}{c}\text { Regula o } \\
\text { Programa } \\
\text { Minha } \\
\text { Casa } \\
\text { Minha } \\
\text { Vida - } \\
\text { Entidades }\end{array}$ & 2016 & $\begin{array}{c}\text { RESOLUÇÃ } \\
\mathrm{O}\end{array}$ & 214 & $\begin{array}{c}\text { Aprova o } \\
\text { Programa Minha } \\
\text { Casa, Minha } \\
\text { Vida - Entidades - } \\
\text { PMCMV E. }\end{array}$ & \begin{tabular}{|c|} 
Trata dos \\
objetivos, participantes \\
e atribuições, \\
beneficiários, \\
modalidade \\
operacionais \\
(construção em terreno \\
próprio ou de \\
terceiros), regimes de \\
construção, condições \\
básicas de
\end{tabular} & $\begin{array}{c}\text { Revoga a Resolução no } \\
200 / 2014 .\end{array}$ & $\begin{array}{l}\frac{\text { http://pesquisa.i }}{\text { n.gov.br/impren }} \\
\frac{\text { sa/isp/visualiza/ } / \text { isplata }}{\text { index.jsp?data }} \\
\frac{23 / 02 / 2017 \& \text { or }}{\text { nal=1\&pagina }=} \\
\frac{\underline{51 \& \text { totalArquivo }}}{\underline{s=84}}\end{array}$ \\
\hline
\end{tabular}




\begin{tabular}{|c|c|c|c|c|c|c|c|c|c|}
\hline & & & & & & & $\begin{array}{c}\text { financiamento, limites } \\
\text { operacionais, contrataç } \\
\text { ão direta da entidade } \\
\text { organizadora, entre } \\
\text { outros. }\end{array}$ & & \\
\hline $\begin{array}{l}\text { CONSELHO } \\
\text { CURADOR } \\
\text { DO FUNDO } \\
\text { DE } \\
\text { DESENVOLV } \\
\text { IMENTO } \\
\text { SOCIAL }\end{array}$ & $\begin{array}{c}\text { RECURSO } \\
\mathrm{S}\end{array}$ & Recursos & 2016 & $\begin{array}{c}\text { RESOLUÇÃ } \\
\text { O }\end{array}$ & 213 & $\begin{array}{l}\text { Propõe a } \\
\text { reavaliação da } \\
\text { política de } \\
\text { investimentos do } \\
\text { Fundo de } \\
\text { Desenvolvimentos } \\
\text { Social - FDS. }\end{array}$ & $\begin{array}{c}\text { Estabelecer que os } \\
\text { recursos do FDS, } \\
\text { alínea "a" do parágrafo } \\
\text { único do Artigo } 3^{\circ} \text {. da } \\
\text { Lei no } 8.677 / 1993, \\
\text { enquanto não } \\
\text { destinados a } \\
\text { financiamentos de } \\
\text { projetos, poderão ser } \\
\text { aplicados pela CAIXA, } \\
\text { sendo até } 10 \% \text { em } \\
\text { Reserva de Liquidez, } \\
\text { sendo } 5 \% \text { em } \\
\text { operações } \\
\text { compromissadas e } 5 \% \\
\text { em títulos de emissão } \\
\text { da CAIXA, até } 100 \% \\
\text { em operações } \\
\text { compromissadas } \\
\text { diárias com a CAIXA, } \\
\text { as quais são lastreadas } \\
\text { exclusivamente por } \\
\text { Títulos Públicos } \\
\text { Federais de emissão } \\
\text { do Tesouro Nacional. }\end{array}$ & $\begin{array}{c}\text { Revoga resolução } \\
131 / 2008 .\end{array}$ & $\begin{array}{c}\frac{\text { http://pesquisa.i }}{\text { n.gov.br/impren }} \\
\frac{\text { sa/isp/visualiza/ }}{\text { index.jsp?data }=} \\
\frac{23 / 02 / 2017 \& \text { jor }}{\text { nal=1\&pagina }=} \\
\frac{51 \& \text { totalArquivo }}{\text { s=84 }}\end{array}$ \\
\hline
\end{tabular}




\begin{tabular}{|c|c|c|c|c|c|c|c|c|}
\hline $\begin{array}{c}\text { CONSELHO } \\
\text { CURADOR } \\
\text { DO FUNDO } \\
\text { DE } \\
\text { DESENVOLV } \\
\text { IMENTO } \\
\text { SOCIAL }\end{array}$ & $\begin{array}{l}\text { REGULAM } \\
\text { ENTO }\end{array}$ & $\begin{array}{l}\text { Plano de } \\
\text { Metas }\end{array}$ & 2016 & $\begin{array}{c}\text { RESOLUÇÃ } \\
\text { O }\end{array}$ & 212 & $\begin{array}{l}\text { Institui novo Plano } \\
\text { de Metas e } \\
\text { Diretrizes } \\
\text { Gerais de } \\
\text { aplicação dos } \\
\text { recursos alocados } \\
\text { junto ao Fundo de } \\
\text { Desenvolvimento } \\
\text { Social } \\
\text { (FDS) para } \\
\text { execução do } \\
\text { Programa Minha } \\
\text { Casa Minha Vida - } \\
\text { Entidades, relativo } \\
\text { ao } \\
\text { Exercício de } 2017 .\end{array}$ & $\begin{array}{c}\text { Institui Plano de Metas } \\
\text { e Diretrizes Gerais de } \\
\text { aplicação dos recursos } \\
\text { alocados junto ao } \\
\text { Fundo de } \\
\text { Desenvolvimento } \\
\text { Social (FDS) para } \\
\text { execução do Programa } \\
\text { Minha Casa Minha } \\
\text { Vida - } \\
\text { Entidades, relativo ao } \\
\text { Exercício de } 2017 \text {, cujo } \\
\text { montante é de até R\$ } \\
796.400 .000 \\
\text { (setecentos e noventa } \\
\text { e seis milhões e } \\
\text { quatrocentos mil } \\
\text { reais). }\end{array}$ & $\begin{array}{l}\frac{\text { http://pesquisa.i }}{\text { n.gov.br/impren }} \\
\frac{\text { sa/jsp/visualiza/ }}{\text { index.jsp?data }=} \\
\frac{23 / 02 / 2017 \& \text { jor }}{\text { nal=1\&pagina }=} \\
\frac{\text { n1\&totalArquivo }}{\underline{\mathrm{s}=84}}\end{array}$ \\
\hline $\begin{array}{c}\text { SECRETARI } \\
\text { A NACIONAL } \\
\text { DE } \\
\text { HABITAÇÃO }\end{array}$ & $\begin{array}{c}\text { RECURSO } \\
\mathrm{S}\end{array}$ & $\begin{array}{c}\text { Suplement } \\
\text { ação de } \\
\text { recursos }\end{array}$ & 2014 & PORTARIA & 736 & \begin{tabular}{|c|} 
Divulga o \\
resultado da \\
suplementação de \\
valores da seleção \\
dos \\
empreendimentos \\
apresentados no \\
âmbito do \\
Programa Minha \\
Casa Minha Vida- \\
Entidades, \\
operado com \\
recursos do Fundo \\
de \\
Desenvolvimento \\
Social - FDS. \\
\end{tabular} & & 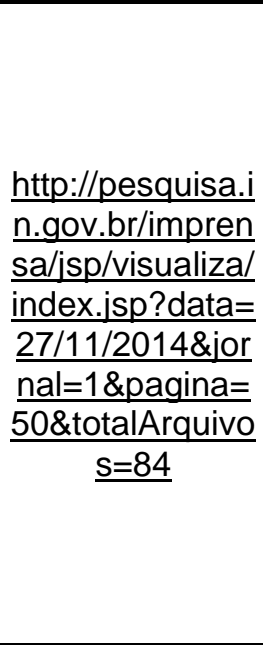 \\
\hline
\end{tabular}




\begin{tabular}{|c|c|c|c|c|c|c|c|c|c|}
\hline $\begin{array}{c}\text { MINISTÉRIO } \\
\text { DAS } \\
\text { CIDADES }\end{array}$ & $\begin{array}{c}\text { ENTIDADE } \\
\mathrm{S}\end{array}$ & $\begin{array}{l}\text { Habilitação } \\
\text { e } \\
\text { requalifica } \\
\text { ção de } \\
\text { entidades }\end{array}$ & 2014 & PORTARIA & 247 & \begin{tabular}{|} 
Estabelece as \\
condições gerais \\
para habilitação e \\
requalificação de \\
entidades privadas \\
sem fins lucrativos, \\
como Entidades \\
Organizadoras, no \\
âmbito dos \\
programas de \\
habitação de \\
interesse social \\
geridos pelo \\
Ministério das \\
Cidades, e o \\
calendário do \\
exercício de 2014.
\end{tabular} & \begin{tabular}{|c|} 
Aprovou Manual de \\
instruções para \\
Habilitação e \\
requalificação de \\
entidades privadas sem \\
fins lucrativos. \\
[http://www.cidades.gov \\
.br/images/stories/Arqui \\
vosCidades/ArquivosP \\
DF/manualdeinstrucoes \\
habilitacao.pdf]
\end{tabular} & $\begin{array}{c}\text { Fica revogada a } \\
\text { Portaria no } 107 / 2013 .\end{array}$ & $\begin{array}{l}\frac{\text { http://pesquisa.i }}{\text { n.gov.br/impren }} \\
\frac{\text { sa/jsp/visualiza/ }}{\text { index.jsp?jornal }} \\
\frac{\equiv 1 \text { \&pagina }=59}{\text { \&data }=07 / 05 / 20} \\
\underline{14}\end{array}$ \\
\hline $\begin{array}{c}\text { MINISTÉRIO } \\
\text { DAS } \\
\text { CIDADES }\end{array}$ & $\begin{array}{c}\text { RECURSO } \\
\mathrm{S}\end{array}$ & $\begin{array}{c}\text { Nova } \\
\text { Redação }\end{array}$ & 2014 & $\begin{array}{l}\text { PORTARIA } \\
\text { INTERMINI } \\
\text { STERIAL }\end{array}$ & 237 & $\begin{array}{c}\text { Dá nova } \\
\text { redação aos arts. } \\
2^{\circ} 4^{\circ} \text { e } 8^{\circ} \text { da } \\
\text { Portaria } \\
\text { Interministerial n } \\
464 \text { de } 30 \text { de } \\
\text { setembro de } 2011, \\
\text { que dispõe sobre } \\
\text { as operações com } \\
\text { recursos } \\
\text { transferidos ao } \\
\text { Fundo de } \\
\text { Desenvolvimento } \\
\text { Social - FDS, } \\
\text { contratadas no } \\
\text { âmbito do } \\
\text { Programa } \\
\text { Nacional de } \\
\text { Habitação Urbana }\end{array}$ & Nova redação & $\begin{array}{l}\text { A Portaria à qual faz } \\
\text { menção foi revogada. } \\
\text { Mas as normas a que } \\
\text { se refere no artigo } 2 \\
\text { estão vigentes. }\end{array}$ & $\begin{array}{l}\frac{\text { http://pesquisa.i }}{\text { n.gov.br/impren }} \\
\frac{\text { sa/jsp/visualiza/ }}{\text { index.jsp?data }=} \\
\frac{\text { 06/05/2014\&ior }}{\text { nal=1\&pagina }=} \\
\frac{\underline{50 \& \text { totalArquivo }}}{\underline{s=116}}\end{array}$ \\
\hline
\end{tabular}




\begin{tabular}{|c|c|c|c|c|c|c|c|c|c|}
\hline & & & & & & $\begin{array}{c}\text { - PNHU, integrante } \\
\text { do } \\
\text { Programa Minha } \\
\text { Casa, Minha Vida - } \\
\text { PMCMV, para os } \\
\text { fins que especifica. }\end{array}$ & & & \\
\hline $\begin{array}{c}\text { MINISTÉRIO } \\
\text { DAS } \\
\text { CIDADES }\end{array}$ & $\begin{array}{c}\text { ENTIDADE } \\
\mathrm{S}\end{array}$ & $\begin{array}{l}\text { Habilitação } \\
e \\
\text { requalifica } \\
\text { ção de } \\
\text { entidades }\end{array}$ & 2014 & PORTARIA & 778 & \begin{tabular}{|l} 
Dá nova redação à \\
Portaria no 747 , de \\
10 de dezembro de \\
2014, do Ministério \\
das Cidades, que \\
dispõe sobre as \\
condições para \\
habilitação e \\
requalificação de \\
entidades privadas \\
sem fins lucrativos, \\
para os fins que \\
especifica. \\
\end{tabular} & $\begin{array}{l}\text { Dentre as modificações } \\
\text { estão: entidade não } \\
\text { deve constar nos } \\
\text { cadastros impeditivos } \\
\text { de receber recursos } \\
\text { públicos, não deve se } \\
\text { enquadrar como clube } \\
\text { recreativo, associação } \\
\text { de servidores, dentre } \\
\text { outros. }\end{array}$ & $\begin{array}{c}\text { Revoga o subitem } \\
\text { 3.10.3 do Anexo I da } \\
\text { Portaria } \\
\text { no } 747 / 2014 .\end{array}$ & $\begin{array}{l}\frac{\text { http://pesquisa.i }}{\text { n.gov.br/impren }} \\
\frac{\text { sa/isp/visualiza/ }}{\text { index.jsp?data }=} \\
\frac{12 / 12 / 2014 \& \text { jor }}{\text { nal=1\&pagina }=} \\
\frac{101 \& \text { totalArquiv }}{\text { os }=332}\end{array}$ \\
\hline $\begin{array}{c}\text { MINISTÉRIO } \\
\text { DAS } \\
\text { CIDADES }\end{array}$ & $\begin{array}{c}\text { ENTIDADE } \\
\mathrm{S}\end{array}$ & $\begin{array}{l}\text { Habilitação } \\
\text { e } \\
\text { requalifica } \\
\text { ção de } \\
\text { entidades }\end{array}$ & 2014 & PORTARIA & 747 & $\begin{array}{l}\text { Dispõe sobre as } \\
\text { condições para } \\
\text { habilitação e } \\
\text { requalificação de } \\
\text { entidades privadas } \\
\text { sem fins lucrativos, } \\
\text { para os fins que } \\
\text { especifica. }\end{array}$ & $\begin{array}{l}\text { Trata da habilitação, } \\
\text { condições, processo de } \\
\text { habilitação, } \\
\text { requalificação, } \\
\text { regularidade } \\
\text { institucional, } \\
\text { qualificação técnica. }\end{array}$ & $\begin{array}{c}\text { [O subitem } 3.10 .3 \text {, do } \\
\text { Anexo I, desta Portaria } \\
\text { está revogado]. } \\
\text { Revoga também a } \\
\text { Portaria no } 247 / 2014\end{array}$ & $\begin{array}{l}\frac{\text { http://pesquisa.i }}{\text { n.gov.br/impren }} \\
\frac{\text { sa/jsp/visualiza/ }}{\text { index.jsp?data }=} \\
\frac{02 / 12 / 2014 \& \text { jor }}{\text { nal=1\&pagina }=} \\
\frac{\text { 36\&totalArquivo }}{\underline{s=100}}\end{array}$ \\
\hline
\end{tabular}




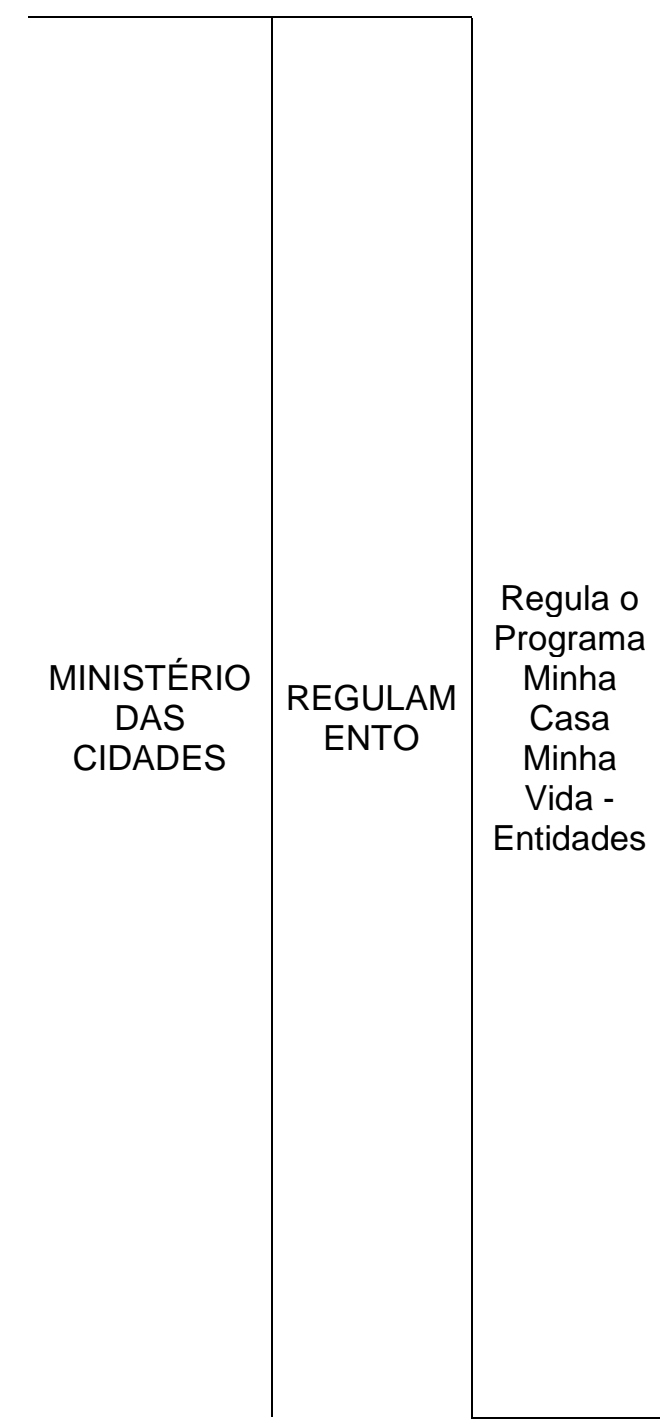

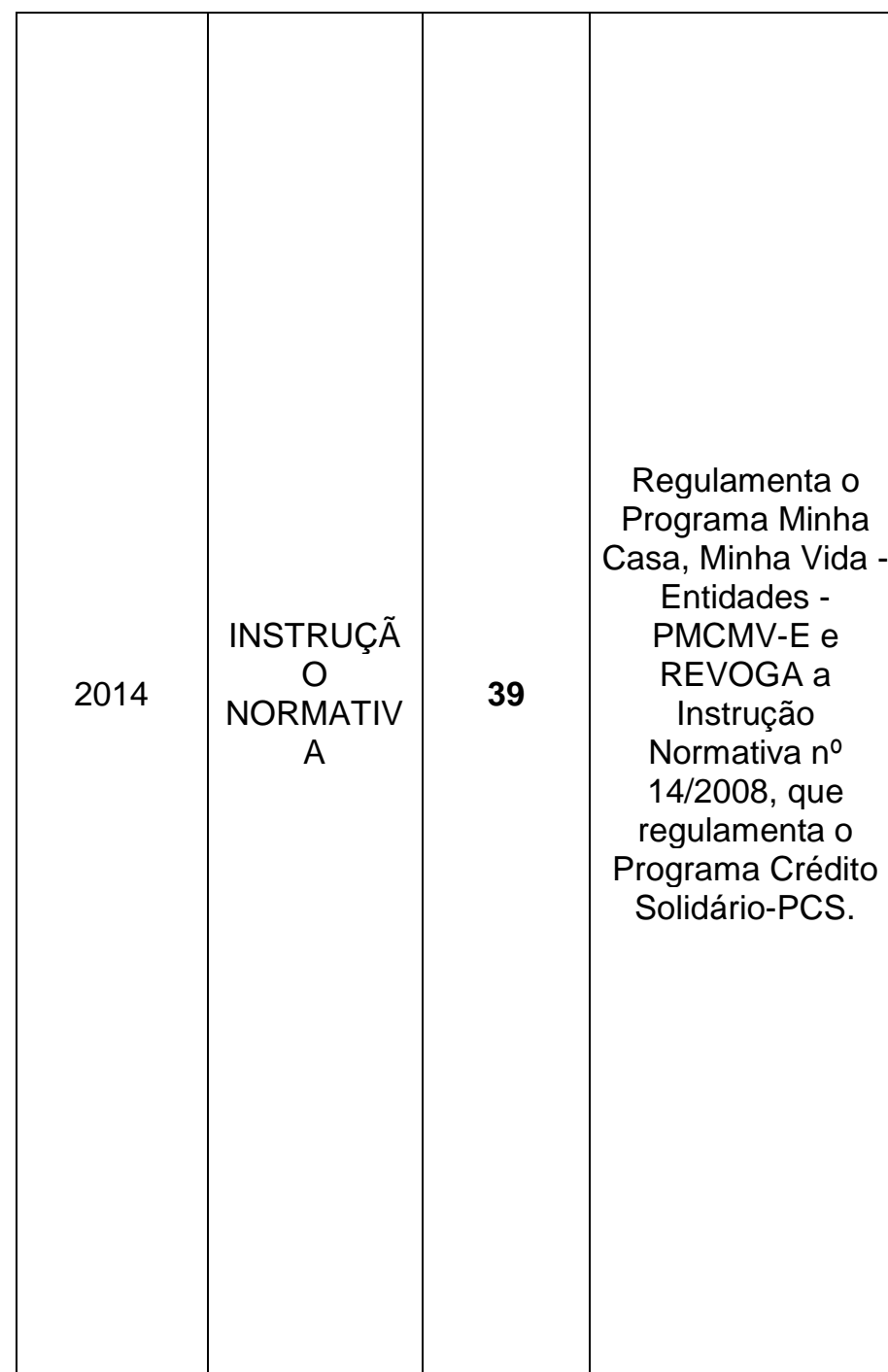

\section{Origem dos}

recursos, participantes

do programa e

atribuições, público

alvo, modalidades de beneficiamento

(pessoa física e pessoa

jurídica), regime de construção, composiçã

o do valor de

investimento, limites operacionais, valor da

operação, diretrizes

para elaboração de

projetos, trabalho

social, processo de

seleção das propostas,

seleção e listagem dos

beneficiários, cobertura

e responsabilidade do

FDS, critério para

liberação de parcelas

durante a fase de

produção, conta do

movimento dos

recursos do FDS,

prorrogação do prazo e

carência, aporte dos

recursos,

monitoramento e

avaliação, orientação

para elaboração de

relatório de diagnóstico

da demanda por

equipamentos e art. 1으 Anexos

foram revogados.

http://www.lexe

ditora.com.br/le

gis 26319513

NSTRUCAO

NORMATIVA

N 39 DE 19

DE DEZEMBR

O DE 2014.as

px 


\begin{tabular}{|c|c|c|c|c|c|c|c|c|}
\hline & & & & & & & $\begin{array}{c}\text { serviços públicos e } \\
\text { urbanos }\end{array}$ & \\
\hline $\begin{array}{c}\text { CONSELHO } \\
\text { DAS } \\
\text { CIDADES }\end{array}$ & $\begin{array}{l}\text { DIFICULD } \\
\text { ADES }\end{array}$ & $\begin{array}{l}\text { Dificuldade } \\
\text { s do } \\
\text { Programa }\end{array}$ & 2014 & $\begin{array}{c}\text { RESOLUÇÃ } \\
O \\
\text { RECOMEN } \\
\text { DADA }\end{array}$ & 173 & \begin{tabular}{|c|} 
Recomenda ao \\
Ministério das \\
Cidades e à \\
Caixa Econômica \\
Federal a criação \\
de uma \\
força-tarefa com o \\
objetivo de realizar \\
um \\
diagnóstico \\
detalhado das \\
dificuldades \\
específicas de \\
execução dos ritos \\
processuais no \\
Programa Minha \\
Casa, Minha Vida - \\
Entidades.
\end{tabular} & $\begin{array}{l}\text { A resolução fala de } \\
\text { dificuldades de } \\
\text { execução, dificuldade } \\
\text { na entrega dos imóveis } \\
\text { e documentação final } \\
\text { das UH, dificuldades de } \\
\text { apoio técnico que as } \\
\text { Entidades enfrentam } \\
\text { em suas ações, } \\
\text { dificuldade na } \\
\text { efetivação da entrega } \\
\text { formal da unidade } \\
\text { residencial (que pode } \\
\text { gerar ocupações } \\
\text { indevidas). }\end{array}$ & $\begin{array}{l}\frac{\text { http://pesquisa.i }}{\text { n.gov.br/impren }} \\
\frac{\text { sa/jsp/visualiza/ }}{\text { index.jsp?data }=} \\
\frac{\text { 06/03/2015\&jor }}{\text { nal=1\&pagina }=} \\
\frac{57 \& \text { totalArquivo }}{\underline{s}=200}\end{array}$ \\
\hline
\end{tabular}




\begin{tabular}{|c|c|c|c|c|c|c|c|c|c|}
\hline $\begin{array}{l}\text { CONSELHO } \\
\text { DAS } \\
\text { CIDADES }\end{array}$ & $\begin{array}{l}\text { REGULAM } \\
\text { ENTO }\end{array}$ & Metas & 2014 & $\begin{array}{l}\text { RESOLUÇÃ } \\
\text { O } \\
\text { RECOMEN } \\
\text { DADA }\end{array}$ & 161 & $\begin{array}{c}\text { Recomenda a } \\
\text { ampliação de } \\
\text { metas para o } \\
\text { Programa Minha } \\
\text { Casa, Minha Vida. }\end{array}$ & $\begin{array}{c}\text { Tem como referência o } \\
\text { ano de } 2014 .\end{array}$ & $\begin{array}{c}\text { Vale para programa } \\
\text { como um todo e não só } \\
\text { para FDS. }\end{array}$ & $\begin{array}{l}\frac{\text { http://pesquisa.i }}{\text { n.gov.br/impren }} \\
\frac{\text { sa/isp/visualiza/ }}{\text { index.jsp?data }=} \\
\frac{\text { 20/10/2014\&jor }}{\text { nal=1\&pagina }=} \\
\frac{\text { 63\&totalArquivo }}{\underline{\text { s=108 }}}\end{array}$ \\
\hline $\begin{array}{l}\text { CONSELHO } \\
\text { DAS } \\
\text { CIDADES }\end{array}$ & $\begin{array}{l}\text { INFRAEST } \\
\text { RUTURA }\end{array}$ & $\begin{array}{l}\text { Infraestrut } \\
\text { ura }\end{array}$ & 2013 & $\begin{array}{l}\text { RESOLUÇÃ } \\
\text { O } \\
\text { RECOMEN } \\
\text { DADA }\end{array}$ & 154 & $\begin{array}{l}\text { Recomenda a } \\
\text { destinação de } \\
\text { recursos para } \\
\text { equipamentos } \\
\text { públicos no } \\
\text { programa Minha } \\
\text { Casa Minha Vida } \\
\text { Entidades. }\end{array}$ & $\begin{array}{c}\text { Praticados nas capitais } \\
\text { estaduais. }\end{array}$ & & 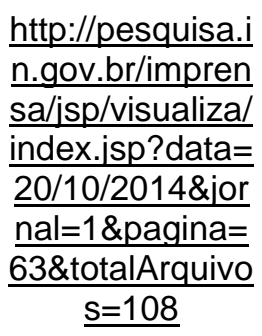 \\
\hline $\begin{array}{l}\text { CONSELHO } \\
\text { DAS } \\
\text { CIDADES }\end{array}$ & $\begin{array}{l}\text { RECURSO } \\
\mathrm{S}\end{array}$ & Recursos & 2013 & $\begin{array}{l}\text { RESOLUÇÃ } \\
\text { O } \\
\text { RECOMEN } \\
\text { DADA }\end{array}$ & 156 & $\begin{array}{l}\text { Recomenda ao } \\
\text { Ministério das } \\
\text { Cidades e ao } \\
\text { Conselho Curador } \\
\text { do Fundo de } \\
\text { Desenvolvimento } \\
\text { Social (CCFDS) a } \\
\text { equiparação de } \\
\text { valores de } \\
\text { produção de } \\
\text { unidades } \\
\text { habitacionais do } \\
\text { Programa Minha } \\
\text { Casa Minha Vida } \\
\text { Entidades em } \\
\text { capitais regionais } \\
\text { aos valores } \\
\text { praticados nas } \\
\text { capitais estaduais. }\end{array}$ & $\begin{array}{l}\text { Equiparação de valores } \\
\text { de produção de UH do } \\
\text { Programa Minha Casa } \\
\text { Minha Vida- Entidades } \\
\text { em capitais regionais } \\
\text { aos valores praticados } \\
\text { nas capitais estaduais. }\end{array}$ & & $\begin{array}{l}\frac{\text { http://pesquisa.i }}{\text { n.gov.br/impren }} \\
\frac{\text { sa/isp/visualiza/ }}{\text { index.jsp?data }=} \\
\frac{20 / 10 / 2014 \& j o r}{\text { nal=1\&pagina }=} \\
\frac{\frac{63 \& \text { totalArquivo }}{s=108}}{\underline{s}}\end{array}$ \\
\hline
\end{tabular}




\begin{tabular}{|c|c|c|c|c|c|c|c|c|c|}
\hline $\begin{array}{c}\text { MINISTÉRIO } \\
\text { DAS } \\
\text { CIDADES }\end{array}$ & $\begin{array}{c}\text { ENTIDADE } \\
\mathrm{S}\end{array}$ & $\begin{array}{l}\text { Diretrizes } \\
\text { gerais } \\
\text { habilitação } \\
\text { de } \\
\text { entidades }\end{array}$ & 2012 & PORTARIA & 191 & \begin{tabular}{|} 
Dá nova redação \\
ao Anexo III da \\
Portaria no 105, de \\
2 de março de \\
2012 , do Ministério \\
das Cidades, e \\
outras \\
providências.
\end{tabular} & Cronograma. & $\begin{array}{c}\text { Nova redação ao } \\
\text { Anexo III da Portaria no } \\
\text { 105/2012 / Revoga o } \\
\text { Anexo I da Portaria no } \\
\text { 313/2010. }\end{array}$ & 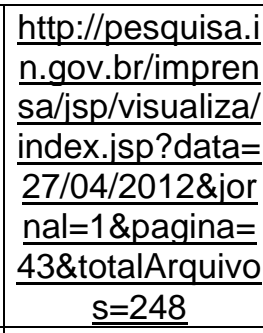 \\
\hline $\begin{array}{c}\text { MINISTÉRIO } \\
\text { DAS } \\
\text { CIDADES }\end{array}$ & $\begin{array}{c}\text { ENTIDADE } \\
\mathrm{S}\end{array}$ & $\begin{array}{l}\text { Diretrizes } \\
\text { gerais } \\
\text { habilitação } \\
\text { de } \\
\text { entidades }\end{array}$ & 2012 & PORTARIA & 105 & $\begin{array}{c}\text { Estabelecer as } \\
\text { diretrizes gerais e } \\
\text { o cronograma para } \\
\text { habilitação de } \\
\text { entidades privadas } \\
\text { sem fins lucrativos, } \\
\text { como Entidade } \\
\text { Organizadora - } \\
\text { EO, no âmbito dos } \\
\text { programas de } \\
\text { habitação de } \\
\text { interesse social } \\
\text { geridos pelo } \\
\text { Ministério das } \\
\text { Cidades } \\
\text { direcionados ao } \\
\text { atendimento da } \\
\text { demanda } \\
\text { organizada por EO } \\
\text { ou executados } \\
\text { com recursos do } \\
\text { Fundo Nacional de } \\
\text { Habitação de } \\
\text { Interesse Social } \\
\text { (FNHIS) e do } \\
\text { Fundo de } \\
\text { Desenvolvimento } \\
\text { Social (FDS). }\end{array}$ & $\begin{array}{l}\text { Trata do objetivo, da } \\
\text { competência para } \\
\text { Caixa Econômica, } \\
\text { apresenta formulário de } \\
\text { habilitação, declaração } \\
\text { de dirigente máximo, } \\
\text { dentre outros... }\end{array}$ & $\begin{array}{c}\text { Olhar a } \\
\text { Portaria 191/2012 que } \\
\text { traz nova redação para } \\
\text { o anexo III. }\end{array}$ & $\begin{array}{l}\frac{\text { http://pesquisa.i }}{\text { n.gov.br/impren }} \\
\frac{\text { sa/jsp/visualiza/ }}{\text { index.jsp?data }=} \\
\frac{13 / 03 / 2012 \& \text { jor }}{\text { nal=1\&pagina }=} \\
\frac{\underline{41 \& \text { totalArquivo }}}{\underline{s=196}}\end{array}$ \\
\hline
\end{tabular}




\title{
ANEXO 3 - Termo de Consentimento Entrevista
}

\author{
Entrevista semiestruturada: A implementação do MCMV Faixa 1 em São Paulo
}

Dissertação de Mestrado - Departamento Econômico Financeiro - Faculdade de Direito da USP

Orientador: Diogo Rosenthal Coutinho

\section{TERMO DE CONSENTIMENTO}

Projeto de pesquisa: A implementação do MCMV Faixa 1 no Município de São Paulo

Proposta da pesquisa: O objetivo deste trabalho é analisar como as modalidades do Programa Minha Casa, Minha Vida (MCMV) destinadas a população que ganha entre zero e três salários mínimos (Faixa 1) foram implementadas no Município de São Paulo, buscando compreender quais foram as oportunidades geradas e as dificuldades de implementação de um programa desenhado a partir do govemo federal pela maior Prefeitura do país.

Finalidade da entrevista: a partir de entrevistas semiestruturadas se objetiva compreender quais são as dificuldades impostas aos gestores na implementação da política pública no município de São Paulo, bem como entender se e como surgiram soluções e adaptações na execução do MCMV Faixa 1 na cidade.

Uso da entrevista: $O$ conteúdo da entrevista será aproveitado unicamente para fins acadêmicos da pesquisa. Confidencialidade: Trechos das entrevistas poderão ser declarados confidenciais pelo entrevistado ao longo da entrevista. Anonimato: Se o entrevistado expressamente manifestar pelo resguardo de sua identificação, as transcrições e citações indicarão apenas em qual instituição e periodo o entrevistado trabalhou na Prefeitura ou no governo federal (Secretaria de Habitação - Gestão Kassab/Haddad/Doria, Ministério das Cidades-Governo Lula/Dilma/Temer).

Consentimento: Eu, estou de acordo em participar da pesquisa supramencionada.

Assino duas cópias do presente, sendo uma para mim.

$\square$ Desejo que trechos identificados da entrevista sejam confidenciais.

$\square \square$ Desejo que minha identidade seja resguardada.

Assinatura do(a) entrevistado:

Assinatura do(a) entrevistador(a):

Data: 


\section{ANEXO 4 - Roteiro de Entrevista Semiestruturada com Gestores Municipais}

\section{Perfil do Entrevistado}

Nome:

Cargo/órgão que ocupou na administração municipal:

Gestão:

Quais as atividades desenvolvidas pelo entrevistado em relação ao MCMV Faixa 1?

\section{PERCEPÇÃO GERAL SOBRE A IMPLEMENTAÇÃO - DIFICULDADES E INOVAÇÕES}

- Qual era a relevância do MCMV Faixa 1 para o provimento de HIS no município de São Paulo na época em que você atuou como gestor público na Prefeitura de São Paulo? Por que você considera que a política tinha esse grau de relevância? Quais fatores você levou em consideração para atribuir essa relevância?

- Quão adequado você considera o desenho federal do MCMV Faixa 1 para as necessidades habitacionais de São Paulo? Quais fatores você levou em consideração para atribuir esse grau de adequação?

- Considerando a resposta anterior e o desenho federal do programa, quais as dificuldades que você verificou ou das quais tomou ciência em sua atuação na implementação no Município de São Paulo? Como você classificaria essas dificuldades? De que ordem são?

- Quais foram as adaptações de que o Município lançou mão para viabilizar a implementação do programa na cidade (legais, contratuais, cooperação com outros entes etc) de que você tenha ciência? Como elas sugiram? Por que motivos?

- Como você avalia as adaptações adotadas? Elas conseguiram solucionar os problemas a que se propunham? Se sim, por quê? Se não, por quê? (adaptações não implementadas)

\section{PERCEPÇÃO GERAL SOBRE AS ATRIBUIÇÕES LEGAIS DO MUNICÍPIO NO DESENHO DO PROGRAMA}

- Como você percebeu a atuação da Prefeitura de São Paulo no cumprimento das seguintes diretrizes legais estabelecidas na Lei Federal do MCMV (art. $3^{\circ}$, $\S^{1} \stackrel{\circ}{\text { ) e quão }}$ relevantes elas eram para a implementação do programa:

1. Doação de terrenos em área urbana consolidada para implantação de empreendimentos vinculados ao programa;

2. Desoneração tributária para as construções destinadas à HIS;

3. Utilização dos instrumentos urbanísticos previstos no Estatuto da Cidade para retenção das áreas urbanas em ociosidade (utilização de ZEIS, captação de recursos do FUNDURB para HIS).

- Houve dificuldades ou adaptações necessárias na atuação da Prefeitura em relação aos temas da pergunta anterior?

- Como você enxerga o processo de desapropriação dos terrenos para viabilizar os empreendimentos? Há dificuldades para o município viabilizar essas desapropriações? Se sim, quais? Houve alguma solução diferente implementada pela Prefeitura para viabilizar essas desapropriações? Se sim, quais? 
- Enquanto no MCMV Faixa 1 FAR a demanda de beneficiários é feita pelo Município, no caso do Entidades esse cadastro é feito pela própria entidade que fica responsável por indicar uma demanda fechada para seus empreendimentos. Como você percebia a diferença de cadastro de beneficiários entre o FAR e o Entidades? Quais eram as dificuldades dos cadastros de cada uma dessas modalidades?

- O município adota critérios de priorização de beneficiários diferentes do governo federal. Por que ele os adotou - mulheres vítima de violência doméstica (Haddad), pais monoparentais (Kassab) etc?

- Como você vê o papel da Prefeitura na implementação do MCMV Faixa 1 Entidades? Houve alguma dificuldade ou adaptação pela Prefeitura para implementação da modalidade? (cadastro de beneficiários, doações de terreno, cumprimento de critérios do Ministério das Cidades pelas entidades, etc)

- Como você viu a fiscalização do Município sobre os empreendimentos do MCMV Faixa 1 ?

- Há dificuldades específicas nos processos de licenciamento dos empreendimentos do MCMV Faixa 1? De que ordem? Como o município tenta superar essas eventuais dificuldades?

\section{PERCEPÇÃO GERAL SOBRE O ARRANJO INSTITUCIONAL DO PROGRAMA}

- Como você vê a coordenação da atuação da Prefeitura de São Paulo em relação aos seguintes entes na implementação do MCMV Faixa 1:

- Governo Federal (especialmente Ministério das Cidades)

- Governo Estadual

- Bancos Públicos Federais (i.e., Caixa Econômica Federal)

- Entidades organizadoras (i.e., movimentos sociais)

- Empreiteiras

- Você acha que os funcionários da Prefeitura tiveram capacidade técnica suficiente para implementar a política? Algum tipo de treinamento ou adequação foi necessário para que a equipe da Prefeitura conseguisse implementar a política na cidade?

- Você acha que o alinhamento político entre o governo federal e o municipal exerce alguma influência na implementação do programa? Se sim, como?

\section{PERCEPÇÃO FINAL - QUESTÕES ESPECÍFICAS}

- Como você vê o enquadramento da demanda por habitação de interesse social na cidade em relação aos critérios de financiamento da Caixa no caso do MCMV Faixa 1 (i.e., famílias com renda de até $\mathrm{R} \$ 1800)$ ?

- Existe alguma relação entre as políticas de urbanização de favela ou remoções de motivo por risco e o MCMV Faixa 1 no município de São Paulo? Se sim, qual?

- Alguma consideração adicional sobre o tema? 